Florida International University FIU Digital Commons

4-7-1995

\title{
Inflation, currency substitution, and dollarization : the case of Argentina
}

Eugenio J. Alemán

Florida International University

DOI: $10.25148 /$ etd.FI13101570

Follow this and additional works at: https://digitalcommons.fiu.edu/etd

Part of the Economics Commons

\section{Recommended Citation}

Alemán, Eugenio J., "Inflation, currency substitution, and dollarization : the case of Argentina" (1995). FIU Electronic Theses and Dissertations. 1224.

https://digitalcommons.fiu.edu/etd/1224

This work is brought to you for free and open access by the University Graduate School at FIU Digital Commons. It has been accepted for inclusion in FIU Electronic Theses and Dissertations by an authorized administrator of FIU Digital Commons. For more information, please contact dcc@fiu.edu. 


\section{FLORIDA INTERNATIONAL UNIVERSITY}

Miami, Florida

INFLATION, CURRENCY SUBSTITUTION AND DOLLARIZATION:

THE CASE OF ARGENTINA

A dissertation submitted in partial satisfaction of the

requirements for the degree of

DOCTOR OF PHILOSOPHY

IN

ECONOMICS

by

Eugenio J. Alemán 
To: Dean Arthur W. Herriott

College of Arts and Sciences

This dissertation, written by Eugenio J. Alemán, and entitled INFLATION, CURRENCY SUBSTITUTION AND DOLLARIZATION: THE CASE OF ARGENTINA, having been approved in respect to style and intellectual content, is referred to you for judgement.

We have read this dissertation and recommend that it be approved.

Mąria Willumsen
Enriequevillamor
Cem Karayalçin
Jorge Salazar-Carrillo, Major Professor

Date of Defense: April 7, 1995

The dissertation of Eugenio J. Alemán is approved.

Dean Arthur W. Herriott
College of Arts and \$ \$ciences
Dr. Richard L. Campbill
Dean of Graduate Studies

Florida International University, 1995 
C COPYRIGHT 1995 by Eugenio J. Alemán

All rights reserved

iii 
This dissertation is dedicated to my wife Conchy. Without her help, sacrifice, and understanding during these long five years this dissertation would have never been possible. María Belén and Eugenio Alejandro also contributed their own share during these years. I would also like to thank my parents Roberto and Susana for their continual support and encouragement. 


\section{ACKNOWLEDGMENTS}

I would like to thank the members of my committee for their help in the successful completion of this dissertation. Special thanks go to my major professor, Dr. Jorge Salazar-Carrillo, and to Dr. Cem Karayalçin, Dr. Enrique Villamor, and Dr. Maria Willumsen. I benefited extensively from their comments and predisposition to helping me in achieving this goal. Thank you again. 


\section{ABSTRACT OF THE DISSERTATION \\ Inflation, Currency Substitution and Dollarization: \\ The Case of Argentina \\ by \\ Eugenio J. Alemán \\ Florida International University, 1995 \\ Professor Jorge Salazar-Carrillo, Major Professor}

This dissertation discusses the relationship between inflation, currency substitution and dollarization that has taken place in Argentina for the past several decades.

First, it is shown that when consumers are able to hold only domestic monetary balances (without capital mobility) an increase in the rate of inflation will produce a balance of payments deficit. We then look at the same issue but with heterogeneous consumers, this heterogeneity being generated by non-proportional lump-sum transfers.

Second, we discussed some necessary assumptions related to currency substitution models and concluded that there was no a-priori conclusion on whether 
currencies should be assumed to be "cooperant" or "non-cooperant" in utility. That is to say, whether individuals held different currencies together or one instead of the other.

Third, we went into discussing the issue of currency substitution as being a constraint on governments inflationary objectives rather than a choice of those governments to avoid hyperinflations. We showed that imperfect substitutability between currencies does not "reduce the scope for rational (hyper)inflationary processes" as it had been previously argued. It will ultimately depend on the parametrization used and not on the intrinsic characteristics of imperfect substitutability between currencies.

We further showed that in Argentina, individuals have been able to endogenize the money supply by holding foreign monetary balances. We argued that the decision to hold foreign monetary balances by individuals is always a second best due to the trade-off between holding foreign monetary balances and consumption. For some levels of income, consumption, and foreign inflation, individuals would prefer to hold domestic monetary balances rather than foreign ones.

We then modeled the distinction between dollarization and currency substitution. We concluded that although dollarization is necessary for currency substitution to take place, the decision to use foreign monetary balances for transactions purposes is largely independent from the dollarization process. 
Finally, we concluded that Argentina should not fully dollarize its economy because dollarization is always a second best to using a domestic currency. Further, we argued that a fixed exchange system would be better than a flexible exchange rate or a "crawling-peg" system because of the characteristics of the political system and the possibilities of "mass praetorianism" to develop, which is intricately linked to "populist" solutions. 
CHAPTER

PAGE

\section{INTRODUCTION}

1.1 At the Start of The 20th. Century. 1

1.2 At the Start of The 21st. Century.

II. ARGENTINA: A RECENT HISTORICAL BACKGROUND

2.1 Inflation in Argentina. .14

2.2 Going Global, Going Broke?

2.3 Currency Substitution in Argentina...........................................................31

2.4 Misconceptions About Currency Substitution........................................38

2.4.1 Currency Substitution As A Choice Of Governments.............................39

2.4.2 Currency Substitution Vs. Financial Adaptation....................................41

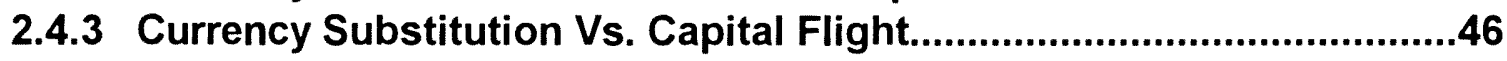

2.4.4 Dollarization Vs. Currency Substitution.................................................47

III. DEVALUATION: ENDOGENOUS RATES OF TIME PREFERENCE AND HETEROGENEOUS AGENTS

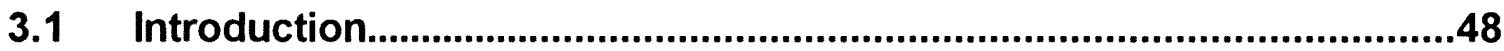

3.2 Assumptions of the Model.................................................................49

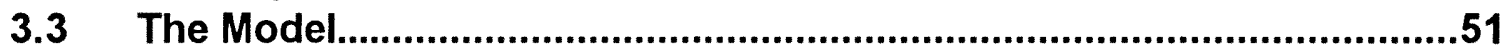

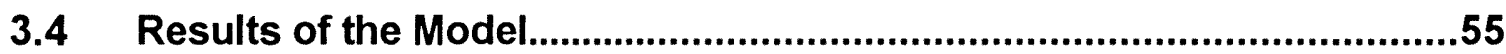

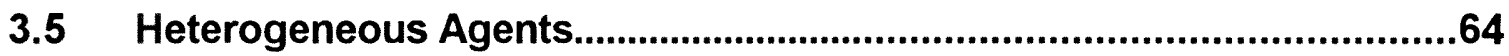

3.6 Redistribution Through Lump-Sum Transfers.......................................66

3.7 Results With Heterogeneous Consumers and Non-Proportional Lump-Sum Transfers............................................................................68

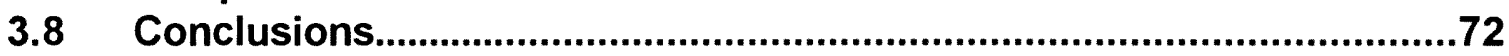

IV. COMMENTS ON THE ASSUMPTIONS USED IN CURRENCY SUBSTITUTION MODELS

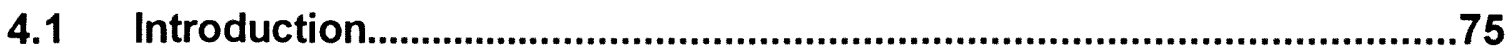

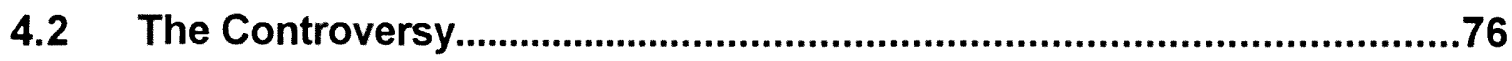

4.3 Cooperancy versus Non-Cooperancy....................................................78 


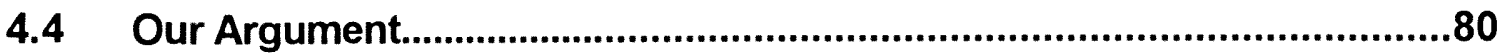

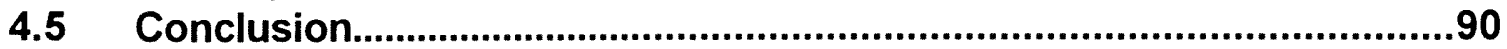

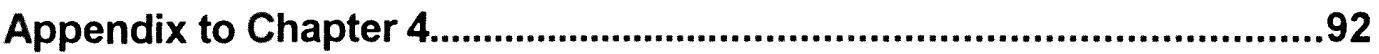

V. RATIONAL HYPERINFLATION WITH CURRENCY SUBSTITUTION

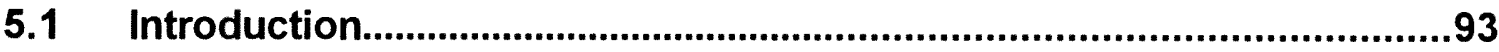

5.2 The Sidrauski Model and Hyperinflations.............................................94

5.3 The Model With Two Fiat Currencies..........................................................98

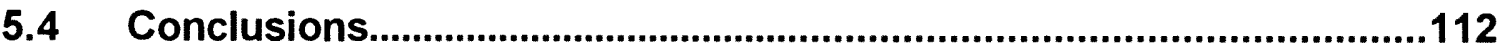

VI. DOLLARIZATION IN ARGENTINA: COOPERANT OR NON-COOPERANT MONETARY BALANCES?

6.1 Introduction

6.2 Trade-Off Between Holding Foreign Monetary Balances and Consumption.

6.3 Two Monies Again: A Foreign and A Domestic One..............................121

6.4 Conclusion. 131

VII. CURRENCY SUBSTITUTION IN ARGENTINA: INTRODUCING AN INDEXED CURRENCY OR ENDOGENOUS MONEY SUPPLY?

7.1 Two Strands of Hyperinflation 133

7.2 Rational Hyperinflation: Introducing An Indexed Currency....................138

7.3 The Case of Argentina: Essential Monetary Balances............................142

7.3.1 The Model With Essential Monetary Balances.........................................142

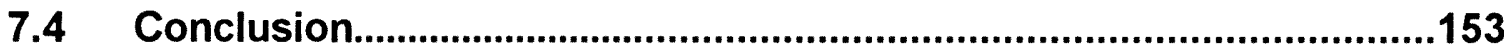

VIII. CONCLUSIONS AND POLICY RECOMMENDATIONS

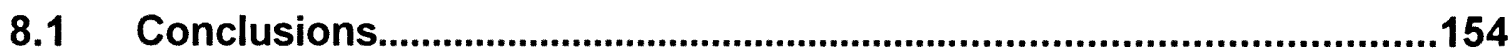

8.2 What Lies Ahead? Policy Recommendations.......................................156

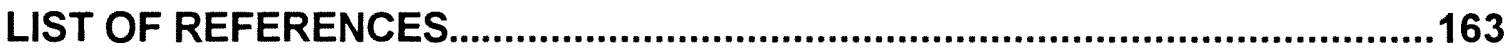




\section{LIST OF FIGURES}

2.1a Inflation Rate (CPI) Argentina 1945-1974................................................15

2.1b Inflation Rate (CPI) Argentina 1975-1994 ...........................................15

2.2 Real M1 and Fiscal Deficit (\% of GDP),..................................................18

3.1 Consumption..............................................................................................

3.2 Real Monetary Balances.........................................................................62

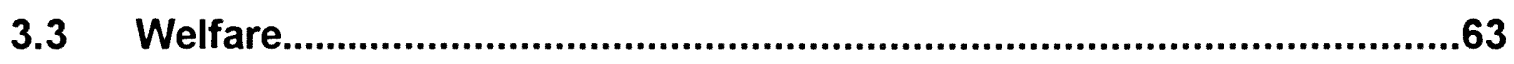

5.1 Rational Hyperinflation.........................................................................97

5.2 Perfect Substitutes (Essential Balances)................................................104

5.3 Imperfect Substitutes..............................................................................106

5.4 Imperfect Substitutes (Growth in Money Supply)..................................110

5.5 Imperfect Substitutes (Inessential Balances)........................................113

6.1 Non-Cooperant Monetary Balances..........................................................128

6.2 Cooperant Monetary Balances (Case 1)...............................................129

6.3 Cooperant Monetary Balances (Case 2).................................................131

7.1 Hyperinflation With Two Inessential Fiat Currencies.............................139

7.2 Monetary Equilibrium With Currency Substitution................................147

7.3 Currency Substitution.............................................................................151 


\section{LIST OF TABLES}

2.1 Real M1 as a Percentage of GDP.

2.2 Fiscal Deficit as a Percentage of GDP.

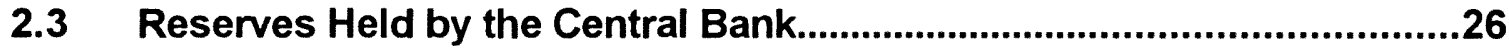

2.4 Argentina's Total Indebtedness and Debt to GDP Ratio......................29 


\section{CHAPTER 1}

\section{INTRODUCTION}

Argentina's history has been plagued by the mismanagement of its fiscal and monetary policy. At the beginning of Argentina as a nation, in the early 1,800 s, this mismanagement came about as a reflection of the lack of integration and institutionalization of its political system. During the middle and late 1900s the country continued to suffer a lack of institutionalization of its political structure complicated further with populists views on the future economic development of the country.

\subsection{AT THE START OF THE $20^{\text {th. }}$ CENTURY}

At the start of the 20th. century, so it has been said, Argentina was one of the most promising countries in the Americas. Argentina was being compared to Canada and Australia as one of the most promising countries. In fact, each time somebody talks about Argentina's misfortunes, they all go back to the beginnings of the century to talk about the "Argentine Miracle." However, a paragraph from Dornbusch (1995) can clarify Argentina's position at the beginnings of this century, it reads:

"At the beginning of the century, Argentina was among the most prosperous 
countries in the world. It is not true that Argentina had an income level equal to that of the United States or the leading country, Britain--in fact, . . . , Argentine per capita income was more nearly half the U.S. level. Argentina is often compared to Australia--both are resource rich and were among the ten most prosperous regions at the beginning of the century. Again Australia already had almost twice the level of per capita income that Argentina showed. Interestingly, Italy closely matched Argentina at the outset of the century and in 1950." (Dornbusch 1995, p. 224)

We chose this paragraph from Dornbusch (1995) because it is a middle ground between the views of the 'liberals' ${ }^{\prime 1}$ and the views of the opposition ${ }^{2}$ within Argentina. The views of the 'liberals' were that Argentina, during the turn of the century, was an 'economic (super?)power' or an 'economic miracle, ${ }^{3}$ while the opposition complained that Argentina's economy had created an extremely high inequality in the distribution of income. In fact, Argentina's historical problems, we argue, are due to the lack of political agreement on how to redistribute income and

${ }^{1}$ Conservative sector composed fundamentally of the rich land-owners. Their economic power was based on land ownership. Of course, they were only liberals with respect to economic freedom. in general.

'Which is composed of the 'peronists' (peronists before Menem) and the 'left'

${ }^{3}$ This issues will be important latter on when we are going to compare those times with these latest years. 
how to minimize income inequality.

Another paragraph, this time from Hyndman (1892), describes Argentina's (or fundamentally Buenos Aires) situation at the turn of the century: ${ }^{4}$

"Buenos Aires surpassed every other city in its luxury, extravagance, and wholesale squandering of wealth. There was literally no limit to the excesses of the wealthier classes. While money, luxuries, and material poured in on the one hand, crowds of immiserization from Italy and other countries flocked in to perpetuate the prosperity of the new Eldorado of the South. Railways, docks, tramways, waterworks, gas-works, public building, mansions, all were being carried on at once in hot haste." (Hyndman 1892, p. 89)

This was the picture of Buenos Aires at the turn of the century in the eyes of a foreigner. And it was not far from reality. However, this was not the biggest problem. The biggest problem was that there was no agreement on how they should distribute such wealth. The political system (i.e., the political institutions) was extremely weak and inefficient. Universal voting was not guaranteed by the law and it was not until the 1916 elections that "full" participation was granted to the population. We say full participation because "voting was not only a right but also

${ }^{4}$ This paragraph was also quoted in Dornbusch 1995.

${ }^{5}$ This full participation was achieved by the Saenz-Peña law of 1912. 
an obligation," with jail terms for those who did not vote.

The year of 1916 marked the break-down in the traditional "elite" dominated political system. However, they still maintained its economic dominance. That is to say, the "liberals" were thrown out of the political power but maintaining their economic handle over their political opposition, which out-numbered them on the ballots as a consequence of the 'Ley Saenz-Peña' of 1912. In the year of 1930, the disagreement between the political majority and the economic minority was such that the political system collapsed and a military "coup d'état" ${ }^{6}$ broke the constitutional continuity of the democratic system.

The disagreement between the political and the economic sectors were tremendous. The 1929 world crisis had an enormous negative effect over the economic conditions of the traditional "elite." Dornbusch (1995) says that "the Depression hit Argentina extra hard. Having built a fortune on a very open economy oriented toward exports of agricultural commodities--wheat and beef--protection in industrial countries and the collapse of world trade and prices had a devastating impact. Even so, the country maintained its international credit by steadfast adherence to debt service and internationalism." (Dornbusch 1995, p. 225)

From the 1930 s to 1944 a succession of fraudulent elections limited full participation in the political system to the rapidly growing native but mostly migrant population. In 1945 Juan D. Perón won the elections and followed a populist

${ }^{6}$ Of course with the consent of the economic minority. 
economic program, which increased the participation of the government in the economic arena, thus increasing the economic inefficiency of the government. ${ }^{7}$

Economic growth during the first decades of this century was high, although the disparities between those who had and those who did not were widening continuously. Yet why is it that nowadays the 'liberals' talk about the beginnings of the century as an example to follow? The reason needs to be found not on this inequality on the distribution of income but on the so called "Conversion Law of 1899."

What was the Conversion Law of 1899 ? Williams (1920) explains this law in the following paragraph: "this law was the result of a project formulated by Finance Minister J. M. Rosa, and supported by ex-President Pellegrini and the well-known Argentine banker, Ernesto Tornquist. The plan was: (I) To fix a ratio according to which redemption of paper money should be made in specie; (2) to accumulate a metallic reserve sufficient to permit such redemption; (3) to maintain the ratio fixed upon by adding to the Caja de Conversión a bureau to act as a regulator of the currency, increasing or decreasing the amount of paper in circulation according to the amount of gold deposited." (Williams 1920, p. 156)

In his conclusions about the Conversion Law of 1899 , Williams argues that

${ }^{7}$ However, this process had started just before the coup d'état of 1930 with the creation of Yacimientos Petroliferos Fiscales (YPF) under the command of General Mosconi.

${ }^{8}$ In 1991, the Ley de Convertivilidad (the Convertibility Law) was passed by the Argentine Congress. 
"it may be pointed out that a prominent force in assuring the success of the Conversion Law has been the succession of favorable balances of international payments which Argentina has enjoyed. The increase of the gold reserve depends directly on that circumstance, and the maintenance of the conversion system itself depends upon the maintenance of that reserve. It is still conceivable that a succession of unfavorable balances, prolonged over as long a period as that of the favorable balances of the last twenty years, would, by draining of the gold reserve, again raise the problem of paper currency. Under such difficult circumstances one is permitted to wonder whether the specie in the Caja de Conversion would continue to be regarded as an inviolable fund." (Williams 1920, p.161)

This argument has an enormous importance nowadays due to the trade deficit suffered by Argentina during these last years.

He argued further that "it is interesting to conclude the consideration of this problem of the relation between inconvertible paper money and the balance of international payments with a quotation from Martinez and Lewandowski. ${ }^{9}$ In commenting upon the conversion plan, they make reference to the criticisms made in some quarters at the rapid increase in the paper money circulation since the law went into operation, which has given rise to the cry that such large emissions may even yet bring back the old problem of debased currency. The reply of these writers

\footnotetext{
${ }^{9}$ Martinez and Lewandowski, Argentina en el Siglo XX, p. 499. [Also quoted by Williams (1920)]
} 
was as follows:

"But it is easy to understand that those alarms are not justified, from the moment in which such emissions are guaranteed by a corresponding deposit in gold in the Caja de Conversión. Besides, if one reflects a little, one cannot do less than recognize that, the product of the surplus of the economic balance of the country being every day more important, this surplus will have an influence on the monetary situation, even though, instead of being conserved in the Caja de Conversion, the surplus should be found in the strong boxes of the private banks."

"Evidently, a favorable balance of payments is recognized as a factor in maintaining the value of the paper currency, ... " (Williams 1920, p. 162)

\subsection{AT THE START OF THE $21^{\text {st. }}$ CENTURY}

What has changed in Argentina during these last 100 years? We could probably say that we are "recycling" history in favor of the old "elite." However, this is not so. Nowadays is not the land-rich class who is the beneficiary of this so called new "Argentine Miracle." The overvaluation of the currency is hurting their traditional exports more than ever before. Furthermore, protectionist policies in some of the biggest countries (or group of them such as NAFTA and the European Community) are preventing Argentina's traditional exports to expand further. Nevertheless, 
growth has been enormous since the application of the Convertibility Law in $1991 .{ }^{10}$ However, that does not mean that most of the population is benefiting from this growth. In fact, income inequality is very high, and a further contributing factor is the extreme ${ }^{11}$ level of unemployment which has reached $12.2 \%$ at the beginning of 1995. The government argues that there is a process of adjustment from the layoffs produced by the privatization of the government owned enterprises but that it will get better in the future. Furthermore, the government passed a labor law through the Argentine Congress which will try minimize the "Argentine cost" in the labor market to make it more responsive to economic changes. ${ }^{12}$

Signs of this rising inequality are ever present in Buenos Aires and in the rest of the country. By looking at some of the new investments taking place in Buenos Aires, one wonders if we could rewrite again that paragraph from Hyndman of his assessment of the situation of Buenos Aires at the beginning of the $20^{\text {th }}$ century: "Buenos Aires surpassed every other city in its luxury, extravagance, and wholesale squandering of wealth. There (is?) was literally no limit to the excesses of the wealthier classes. While money, luxuries, and material poured in on the one hand, crowds of immiserization from..." the Province of Buenos Aires and from the

${ }^{10} \mathrm{GDP}$ has increase $33 \%$ in four years, from 1991-1994.

${ }^{11}$ Extreme for Argentine standards. In fact it is as high as it has ever been. The underemployment rate is on or about $14 \%$ which puts the level of unemployment and underemployment at a historic high of $26.2 \%$.

${ }^{12}$ However, the latest figures on unemployment put this rate at $18.6 \%$ on July of 1995 , twice as much as in 1994. 
rest of the country "...flocked in to perpetuate the prosperity of the new Eldorado of the South." (Hyndman 1892, p. 89)

Nonetheless, many things have changed in Argentina during these 100 years, and two of the most important changes have been: first, the fact that the political system has been opened completely. By this we mean that every sector in society has at least the possibility of actively participating in it. No sector in society has been banned from the political arena, as it used to be the case during almost the entire previous 100 years.

Furthermore, the military sector, an active participant in the political arena during the history of Argentina, has been successfully dismantled and deactivated from any political responsibility and political participation. We say that it has been dismantled and deactivated because its political power came from their economic power, which was based on the ownership and administration of vital industrial sectors of the Argentine economy. ${ }^{13}$

Secondly, and probably for the first time in the history of Argentina, the political power and the economic power seem to share the same views about the new path toward development and growth. Even the political opposition agrees, at least in principle, on what should not be done, which is to go back to the situation that existed before 1991.

${ }^{13}$ Examples were Fabricaciones Militares, YPF, YCF, Comision de Energía Atómica, the Steel Industry, etc., just to give some examples. 
To this respect, Carlos A. Rodriguez (1994a) argues the following: "The significant changes experienced by Argentina after 1990 were a result of a genuine desire on the part of authorities to promote structural adjustment, an attitude partly induced by the debacle caused by hyperinflation. It is clear that after the adjustment that has taken place, it is very unlikely that the economy will revert to its earlier condition. The significant reduction in the size and role of the public sector is not likely to be reversed, either." (Rodriguez 1994, p. 157)

However, this does not mean that populist solutions to income inequality are totally out of the future of Argentina. The lack of integration of the political system, together with the lack of a homogeneous growth across the country limits this positive outlook for the future.

Argentina's high dependency on external, and exogenous variables, further contributes to make the future development even more unstable. The recent Mexican crisis, with what has been called the "tequila effect" over the Latin American economies puts a serious question mark on this type of problems. However, the potentiality of MERCOSUR ${ }^{14}$ and the still dubious, but nonetheless possible, future participation of Argentina in the North American Free Trade Agreement (NAFTA), together with the GATT agreement will tend to minimize the negative effects of the external sector over the Argentine economy.

${ }^{14}$ The South American Common Market, currently composed of Argentina, Brazil, Paraguay and Uruguay. 
The mismanagement of fiscal and fundamentally monetary policy on the part of the Argentine government has given rise to a phenomenon called "currency substitution." By successfully substituting away domestic monetary balances, individuals have tried to evade the inflation tax imposed by this mismanagement of monetary policy. This dissertation analyzes the issue of currency substitution in the context of the Sidrauski model in which money is included in the utility function as a provider of liquidity services.

The dissertation is divided as follows: Chapter 2 discusses some recent historical developments with respect to macroeconomic policy and the use of the money supply to finance huge government deficits. It also deals with a revision of the most important factors and relations between variables affecting the economic process. Some of the variables included are: Inflation Rate, Real $M_{1}$ as a percentage of GDP, Fiscal Deficit as a percentage of GDP, Total Indebtedness and Debt to GDP ratio, etc.

It is also an introduction to the idea of currency substitution and the difference between currency substitution and financial adaptation. It gives reasons why we think that currency substitution is an important factor to take into account in the case of Argentina and, furthermore, the misconceptions about the use of the term.

Chapter 3 is an introduction to the effects of an increase in the rate of inflation on the alternatives of agents when there is no capital mobility. We use the 
Sidrauski model with money in the utility function. Furthermore, agents are assumed to have endogenous rates of time preference. Included also is an analysis of the effects on agents of a non-proportional lump-sum transfer scheme. Several cases are studied.

Chapter 4 is a discussion on the assumptions used in models that deal with currency substitution. We are concerned in this chapter with the distinction between cooperant and non-cooperant real monetary balances. It also serves as an introduction to latter chapters on currency substitution.

Chapter 5 discusses several issues concerning the effects of inflation when we have currency substitution together with the possibility of rational hyperinflationary paths to develop. It is argued that for rational hyperinflations to be possible, currencies cannot be essential in utility.

In Chapter 6 we introduce a new model of dollarization were the foreign currency is accumulated through a balance of payments surplus and agents are not lump-sum compensated for the opportunity cost of holding foreign real monetary balances.

Chapter 7 extends the analysis of Chapter 6 in so far as it introduces currency substitution into the picture to distinguish it from dollarization. An alternative parametrization is used. This parametrization allows agent to endogenize the effects of an increased rate of growth of domestic monetary balances on the optimal decision of agents. 
Chapter 8 is the conclusion and some policy recommendations in the case of Argentina. 


\section{CHAPTER 2}

\section{ARGENTINA: A RECENT HISTORICAL BACKGROUND}

\subsection{Inflation in Argentina}

From 1945 to 1974 Argentina suffered a relatively low rate of inflation (usually, two a digits figure) ${ }^{1}$ compared with the inflation rate characteristic for the period 1975 to 1991 . The period 1975-1991 experienced several hyperinflationary processes, or high inflation processes, ${ }^{2}$ that have contributed to the emergence of a phenomenon called "currency substitution." Individual agents switched to a foreign currency to avoid the effects of the inflation tax (or seigniorage) normally collected by governments in order to minimize the increase in the opportunity cost of holding real monetary balances. That is to say, as inflation increases, the opportunity cost of holding real monetary balances increases as well, which produces a shift away from that instrument in the portfolio of individuals. The inflation rate during this second period never decreased below $100 \%$ per year.

'With several exceptions. In 1953 the inflation rate was 4.0; in 1954, 3.8; in 1959, 113.7; and in 1969, 7.6.

${ }^{2}$ There has been much discussion about the issue of what is considered to be a hyperinflationary level of inflation. In general, Argentina's inflation rate has been far from hyperinflationary. 


\section{Inflation Rate (CPI)}

Argentina 1945-1974

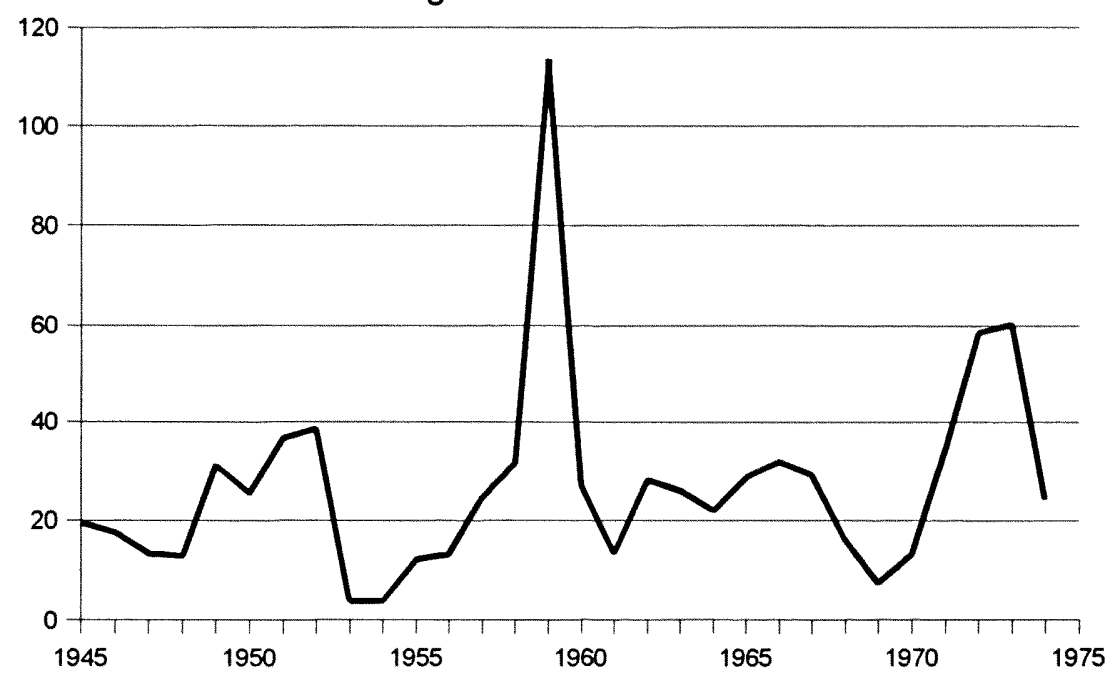

Figure 2.1a

Inflation Rate (CPI)

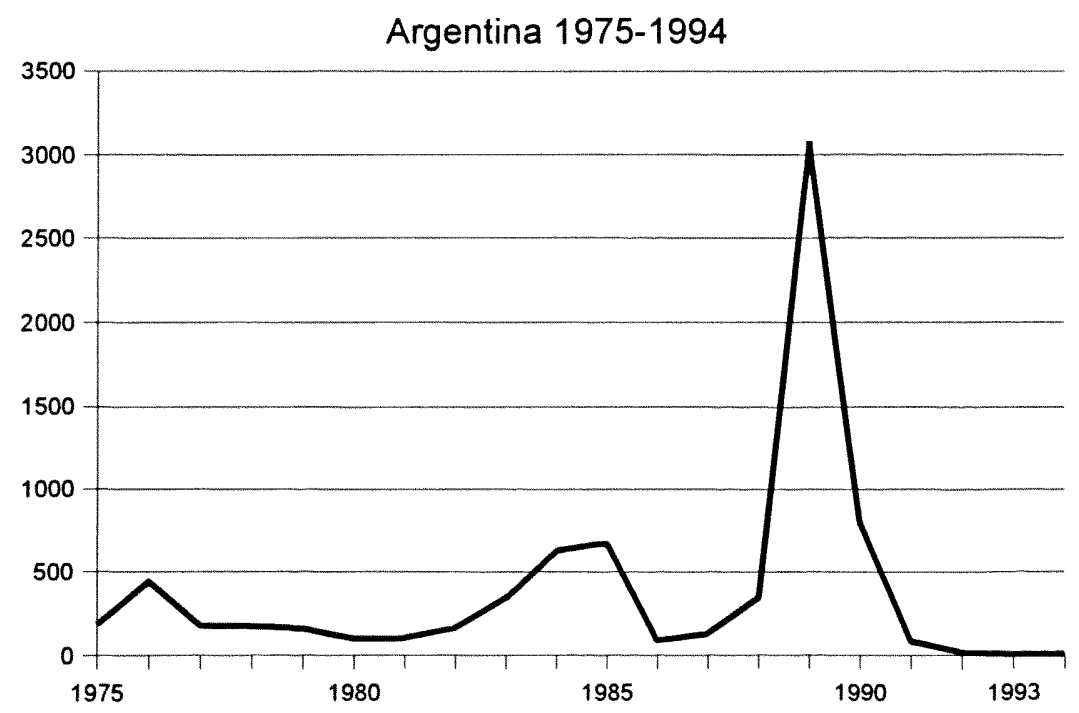

Figure 2.1b 
Figures 2.1a. and 2.1b. show these two periods of inflationary processes. The graph has been divided (from 1945-1974 and from 1975-1994) to differentiate both periods. Note that the vertical axe for Figure 2.1a. goes up to 120 but the same axe for Figure 2.1b. goes as high as 3,500 !

Much has been written in the literature about the causes of these inflationary processes. However, most of them boil down to Friedman's conclusion that "inflation is always and everywhere a monetary phenomenon." That is to say, if the government stops printing money, inflation must disappear.

What we will try to convey throughout this dissertation is that having a domestic money is necessary, if not essential. It is useful to individuals and it is useful for governments. In fact, money is an indispensable instrument in modern economies, so dependent on trade. Without money, trade would be extremely expensive, if not impossible. So, having a sound money should be one of the most important objectives of any government. The problem faced by countries then is defining the use of money to come up with an agreement on the amount of money that is beneficial to everyone, which is not an easy task, especially for Less Developed Countries (LDC's).

Table 2.1 shows the level of real monetary balances (M1), as a percentage of GDP for Argentina during the period 1945-1994. 
Table 2.1

REAL M1 AS A PERCENTAGE OF GDP

\begin{tabular}{|c|c|c|c|c|c|}
\hline YEAR & $m$ & YEAR & Mi & YEAR & min \\
\hline 1945 & 31.1 & 1961 & 17.4 & 1977 & 7.3 \\
\hline 1946 & 33.5 & 1962 & 13.7 & 1978 & 8.1 \\
\hline 1947 & 32.5 & 1963 & 14.4 & 1979 & 7.7 \\
\hline 1948 & 35.6 & 1964 & 15.5 & 1980 & 9.0 \\
\hline 1949 & 36.9 & 1965 & 13.6 & 1981 & 6.2 \\
\hline 1950 & 36.1 & 1966 & 14.5 & 1982 & 5.8 \\
\hline 1951 & 28.2 & 1967 & 14.9 & 1983 & 5.2 \\
\hline 1952 & 27.9 & 1968 & 17.1 & 1984 & 3.8 \\
\hline 1953 & 32.0 & 1969 & 16.3 & 1985 & 4.1 \\
\hline 1954 & 32.7 & 1970 & 14.9 & 1986 & 5.8 \\
\hline 1955 & 32.7 & 1971 & 13.7 & 1987 & 5.2 \\
\hline 1956 & 29.8 & 1972 & 11.3 & 1988 & 3.8 \\
\hline 1957 & 25.5 & 1973 & 15.9 & 1989 & 2.8 \\
\hline 1958 & 21.9 & 1974 & 17.2 & 1990 & 2.5 \\
\hline 1959 & 17.0 & 1975 & 11.5 & 1991 & 4.4 \\
\hline 1960 & 18.9 & 1976 & 8.7 & 1992 & 7.5 \\
\hline & & & & & \\
\hline
\end{tabular}

Sources: The Political Economy of Argentina, 1946-83, Ed. by Guido Di Tella and Rudiger Dornbusch. El Fortalecimiento Del Sector Financiero en el Proceso de Ajuste: Liberalización y Regulación, Roberto Frenkel, Ed. 
Figure 2.2

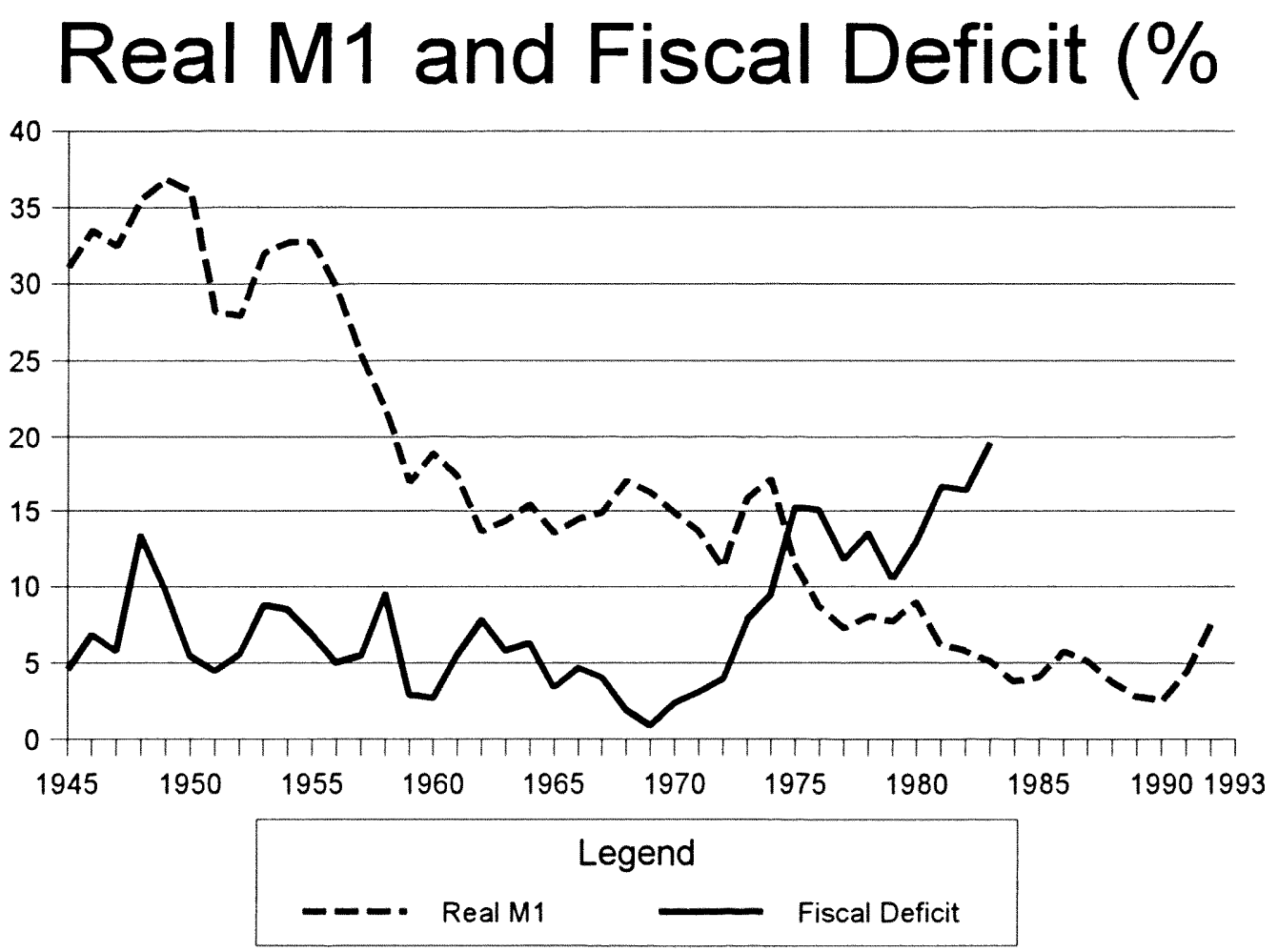

Sources: The Political Economy of Argentina, 1946-1983, Ed. by Guido Di Tella and Rudiger Dornbusch. El Fortalecimiento Del Sector Financiero en el Proceso de Ajuste: Liberalización $y$ Regulación, Roberto Frenkel, Ed.

Table 2.1, if nothing else, shows how individuals have been getting rid of domestic currency holdings for the last five decades. Real monetary balances have decreased from $36.9 \%$ of GDP in 1949 to $3.8 \%$ of GDP in 1984 . One wonders how an economy could go from a level of real monetary balances of almost $37 \%$ of GDP in 1949 to a level of only $3.8 \%$ of GDP in 1984. This is the base of our (and many 
others) argument that there has been a process of demonetization of the Argentine economy together with a process of currency substitution taking place. Table 2.2 shows real domestic monetary balances and fiscal deficit as a percentage of GDP.

One could argue, as Peter N. Ireland does (1994, pp. 47-49) following Wicksell $(1978$, p.66) that as an "economy grows: The gain . . obtained from every saving in the medium of exchange ... constitutes a spur to invention and habitual use of a number of forms of credit which finally become an integral part of the mechanism of trade. At every stage in commercial progress, therefore, we note a new, and generally higher, average velocity of circulation of the medium of exchange, which does not subsequently decrease."13

We have seen the same pattern taking place in Argentina for the last several decades. But we could ask: Are the reasons behind this path similar than for highly developed and high growth countries? The reasons for this trend in high growth countries are given by Ireland (1994 p.48): "If, . . . , demand deposits gradually replace currency and are themselves, in turn, replaced by credit instruments as means of exchange, then a systematic increase in broad monetary aggregates (that include privately issued securities) relative to narrower empirical definitions of money (that are dominated by the government-issued medium of exchange) should be observed within economies over time." Nevertheless, these are not the reasons for "getting out of domestic balances," or getting out of narrow

\footnotetext{
${ }^{3}$ Ireland (1994).
} 
definitions of money in Argentina. This has not been a consequence of high growth and modernization of the Argentine economy. The fact of the matter, for the case of Argentina, is that this demonetization has quite different sources. These sources go from a negative rate of growth for several years since the 1970's to a process of backwardness of the overall economy, to a high dependency on inflationary taxation to sustain the fiscal deficit.

Continuing with our historic analysis, one of the most impressive downward jumps in real monetary holdings was from 1974 to 1975 . What was the reason for this decrease in real monetary holdings by individuals? Table 2.2 will try to give a temporary answer to this question. However, before doing this, we need to say here that the information on Table 2.2 comes from different sources. The different figures between those sources have created several problems. This has been pointed out by several authors of which Daniel Heymann [1987] says: "there has been much debate about the size of the fiscal deficit, mainly referring to the treatment of central bank accounts. ${ }^{14}$

${ }^{4}$ Heymann (1987). 
Table 2.2

FISCAL DEFICIT AS A PERCENTAGE OF GDP

\begin{tabular}{rrrrrr}
\hline Year & Fiscal Deficit & Year & Fiscal Deficit & Year & Fiscal Deficit \\
\hline 1945 & 4.6 & 1965 & 3.4 & 1985 & 9.1 \\
1946 & 6.9 & 1966 & 4.7 & 1986 & 5.2 \\
1947 & 5.8 & 1967 & 4.1 & 1987 & 9.3 \\
1948 & 13.4 & 1968 & 1.9 & 1988 & 9.9 \\
1949 & 9.8 & 1969 & 0.9 & & \\
1950 & 5.5 & 1970 & 2.4 & & \\
1951 & 4.5 & 1971 & 3.1 & & \\
1952 & 5.6 & 1972 & 4.0 & & \\
1953 & 8.8 & 1973 & 7.9 & & \\
1954 & 8.5 & 1974 & 9.5 & & \\
1955 & 6.9 & 1975 & 15.3 & & \\
1956 & 5.0 & 1976 & 15.1 & & \\
1957 & 5.5 & 1977 & 11.8 & & \\
1958 & 9.6 & 1978 & 13.6 & & \\
1959 & 2.9 & 1979 & 10.5 & & \\
1960 & 2.7 & 1980 & 13.0 & & \\
1961 & 5.6 & 1981 & 16.7 & & \\
1962 & 7.9 & 1982 & 16.4 & & \\
1963 & 5.8 & 1983 & 19.4 & & \\
1964 & 6.3 & 1984 & 16.6 & & \\
\end{tabular}

Source : Di Tella and Dornbusch, The Political Economy of Argentina, 1946-83. Kiguel and Liviatan, "The Old and the New in Heterodox Stabilization Programs: Lessons from the Sixties and the Eighties."

We can see here that there are two distinguishable periods, one that goes from 1945 to 1974 and a second one that goes from 1975 to 1990 . As we can see, with one exception in 1948 ( $13.8 \%$ of GDP), the fiscal deficit never increased above $9.8 \%$ of GDP for the period $1945-1974$, and in fact the average fiscal deficit for the period was barely $5.8 \%$ of GDP with the highest being that of 1948 (13.8\% of GDP) and the lowest that of $1969(0.9 \%$ of GDP). In contrast, for the period that started 
in 1975 the situation was completely different in terms of the fiscal deficit. However, this was not because of an effective increase in government expenditures or any other change in policy by the government. This was one of the consequences of the oil crisis of 1974 , which complicated the fiscal situation of the country through the state-owned enterprises, the major instrument for redistributive policies used by the Argentine government. Since these enterprises were a major instrument for redistributive policies, employing a large percentage of the labor force, the government could not reduce employment without creating major social and political disruptions.

To this we have to add the disastrous taxing history of the Argentine government. ${ }^{5}$ As the World Development Report [1988] says, "a 1978 study of income tax in Argentina found that $80 \%$ of gross income was not reported and that only $30 \%$ of 1.6 million people eligible to pay taxes on non-wage income did so."6

In an excellent work by A. Fishlow and J. Friedman (1994) they conclude that: "our estimations suggest that Argentina exhibits very high elasticity of evasion to expected income. Growth is then preceded by sharp increases in the budget deficit. Reliance on additional inflationary financing is doomed to fail because Argentina also exhibits a very high elasticity of evasion to inflation tax. Thus for GNP to expand, the model tells us that Argentina must first secure the financing to

${ }^{5}$ Recently, Carlos A. Rodríguez (1994a) has challenged this argument and in fact argues that the excess tax burden has contributed to the crises in Argentina.

${ }^{6}$ World Development Report [1988], Page 85. 
offset the increased evasion that takes place in the initial stage. If it does not the country will face episodes of high inflation or even hyperinflation that will finally frustrate growth. One may interpret recent policy as doing exactly this."7

Complicating things even further we have to add the fact that the government decided to go to the foreign capital market to finance the deficit, instead of trying to cut it by either selling state-owned enterprises or changing the tax structure and assuring its compliance, or both. ${ }^{8}$

As Jacob Frenkel (1983) argued in this respect: "the liberalization of the capital account is likely to encourage the process of currency substitution. This phenomenon results in an effective reduction of the tax base for inflationary finance. Unless the need for inflationary finance is reduced, the opening up to the capital account and the resultant shrinkage of the inflationary tax base may result in an accelerated rate of inflation as the government attempts to collect the needed revenue from the smaller tax base."

${ }^{7}$ A. Fishlow and J. Friedman (1994), p. 121.

${ }^{8}$ Which is what the Menem administration has achieved through Minister Cavallo's economic plan.

${ }^{9}$ Frenkel (1983), p. 169. 


\subsection{GOING GLOBAL, OR GOING BROKE?}

The military government thought that since the financing of the deficit by internal means (or by money creation, i.e., inflation tax) was producing high inflation, then by going to the foreign capital markets to finance the deficit, inflation would have to subside because the reason for that inflation would have disappeared.

In words of Larry A. Sjaastad [1989] "until 1977, the fiscal deficit was financed by internal inflation, but from that year forward a substantial part was financed by foreign borrowing, a practice that made possible the acquisition of large amounts of international reserves by the Central Bank. Paradoxically, those reserves, accumulated via deficit financing through foreign borrowing, made it possible to sustain the 'Plan del 20 de Diciembre'10 well beyond its period of usefulness [assuming, of course, that it was useful at all] ${ }^{11}$. Nevertheless, there can be no doubt that the persistent fiscal deficit eroded the credibility of the Plan because (a) permanent reliance on foreign finance of the deficit was regarded as implausible if not impossible, and (b) the low rates of inflation implied by a stable

${ }^{10}$ This plan established a preannounced exchange rate depreciation schedule better known as "La Tablita". One of the most distinguishing characteristics was that the rate of devaluation was lower than the rate of internal inflation which implied an appreciation of the real exchange rate or an overvaluation of the local currency.

${ }^{11}$ This comment is ours. 
exchange rate (the final objective of the Plan) could not generate enough 'inflation tax' to finance the fiscal deficit."12

Although the first part of the argument presented above is probably correct, the second part was never a reality because inflation never decreased below $100 \%$ per year with this plan, which would have produced a significant inflation tax to finance the deficit. Of course, this would have been true had it not been for the phenomenon of currency substitution by which individuals successfully avoided this inflation tax by holding foreign currency, and, in our case, by holding U.S. dollars.

We would be looking at the effects of currency substitution over the alternatives available to governments, and to individual consumers in less developed countries and the consequences of this development over the independence and efficiency, or not, of monetary policy.

In fact, what was happening during this period was a huge inflow of reserves and the possibility for the government to subsidize the purchase of dollars by individual consumers or individual firms at a pre-established and changing exchange rate. Rudiger Dornbusch and Juan Carlos de Pablo (1989) say to this respect that "nineteen seventy-nine is a typical year for the combination of policies to attract capital inflows. Interest rates are very high relative to the rate of depreciation. The return from borrowing in New York and lending in Buenos Aires in December 1979, for example, is above 50 percent per year! Moreover, because

${ }^{12}$ Sjaastad (1989). 
of high (and growing) reserves, the policy is believable."13

TABLE 2.3

RESERVES HELD BY THE CENTRAL BANK

\begin{tabular}{cccccc}
\hline Year & Reserves & Year & Reserves & Year & Reserves \\
\hline 1945 & 1,639 & 1965 & 265.1 & 1985 & 4,702 \\
1946 & 1,733 & 1966 & 251.1 & 1986 & $4,426.2$ \\
1947 & 1,175 & 1967 & 754.4 & 1987 & $3,732.5$ \\
1948 & 772 & 1968 & 792.4 & 1988 & 5,157 \\
1949 & 664 & 1969 & 560.2 & 1989 & 3,643 \\
1950 & 843.2 & 1970 & 724.7 & 1990 & 4,432 \\
1951 & 707.6 & 1971 & 316.7 & 1991 & 6,599 \\
1952 & 608 & 1972 & 529 & 1992 & 10,558 \\
1953 & 633.4 & 1973 & $1,412.4$ & 1993 & 13,864 \\
1954 & 654.3 & 1974 & $1,340.8$ & 1994 & 17,600 \\
1955 & 509.2 & 1975 & 617.7 & & \\
1956 & 433.6 & 1976 & $1,771.9$ & & \\
1957 & 333.2 & 1977 & $3,862.4$ & & \\
1958 & 179.1 & 1978 & $5,828.9$ & & \\
1959 & 396.5 & 1979 & $10,137.6$ & & \\
1960 & 702.9 & 1980 & $7,288.3$ & & \\
1961 & 501.9 & 1981 & $3,719.1$ & & \\
1962 & 195.8 & 1982 & $3,047.8$ & & \\
1963 & 326.9 & 1983 & $3,213.2$ & & \\
1964 & 198 & 1984 & $2,590.9$ & &
\end{tabular}

Sources: The Political Economy of Argentina, 1946-1983, Ed. by Guido Di Tella and Rudiger Dornbusch. "Fundación Mediterránea Newsletter," Several Issues.

In fact, a characteristic that differentiates Argentina's debt problem from the rest of the Latin American countries is that "in Argentina's case the government has

${ }^{13}$ Rudiger Dornbusch and Juan Carlos de Pablo, 1989. 
an external debt, but the private sector has matching external assets."14 That is to say, there was a process of redistribution of income and accumulation of wealth toward the sectors that could get hold of foreign currency, principally the export and import sectors and some industrial and service sectors involved with the military government. Nevertheless, not every sector in society had the possibility of taking advantage of this situation. In fact the Martinez de Hoz ${ }^{15}$ period was known in Argentina as the period of the "Plata Dulce" (or Sweet Money).

Furthermore, by various estimates, [Dornbusch, 1985; Watson et al. 1986; Rodriguez, 1986] capital flight from Argentina ${ }^{16}$ amounted to approximately 24 billion dollars for the period 1979-1982 alone. Of course, these estimates include one of the oldest ways (and one of the more effective ones during periods of forced capital immobility) to get away with "illegal capital flight" from any country. This is the under invoicing of exports and the over invoicing of imports.

Ugo Fasano-Filho (1986) has the following comment from Arriazu, an advisor to the Economic Minister of Argentina: "Should we control capital movements? And if the answer is affirmative, can we really control capital movements? ... But do the

${ }^{14}$ Juan Carlos de Pablo and Rudiger Dornbusch (1987).

${ }^{15} \mathrm{~J}$ osé Alfredo Martinez de Hoz was Economic Minister for the military government that took over in 1976.

${ }^{16}$ We say here capital flight from "Argentina" and not from "Argentineans" as some authors like to say because these "Plata Dulce" was not limited only to Argentinean nationals. In fact, who ever brought dollars and invested them in Argentina was guaranteed a return on its "investment" of at least 50 percent. 
authorities control capital movements or does the public? My own experience in Argentina makes me very doubtful of the possibilities of controlling capital flows. In 1975 , for example, Argentina introduced one of the more severe and extensive sets of capital controls in force in the international economy; during that year the current account registered a deficit exceeding US $\$ 1$ billion, at the same time that Argentines accumulated foreign assets abroad also exceeding US $\$ 1$ billion. How could this accumulation take place with so many controls? Basically, through overinvoicing and underinvoicing ... The experience of 1978 also tends to confirm this fact ... In order to stop these flows, the government decided to introduce an interest equalization tax, ... with this measure, capital flows disappeared as such, but capital continued flowing in, now in the form of export prepayments. As a deposit was also required for these flows, capital then began to flow in the form of export pre-financing, and when these flows were also restricted, the movements took the form of overinvoicing and underinvoicing. Exchange sales by tourists also increased during the period, even though these 'tourists' were obviously Argentines."17

Looking at Table 2.4 we can see how the debt grew during this period [197686].

${ }^{17}$ Ugo Fasano-Filho (1986), p. 65. 


\section{Table 2.4}

\section{ARGENTINA'S}

\section{TOTAL INDEBTEDNESS AND DEBT TO GDP RATIO}

\begin{tabular}{ccc}
\hline Year & TOTAL DEBT $^{\star}$ & DEBT/GDP(\%) \\
\hline 1963 & 3,391 & 21.6 \\
1964 & 2,916 & 16.9 \\
1965 & 2,650 & 14.0 \\
1966 & 2,663 & 14.0 \\
1967 & 2,644 & 13.6 \\
1968 & 2,805 & 13.8 \\
1969 & 3,230 & 14.6 \\
1970 & 3,876 & 16.7 \\
1971 & 4,525 & 18.2 \\
1972 & 5,788 & 21.8 \\
1973 & 6,233 & 20.0 \\
1974 & 7,968 & 20.4 \\
1975 & 7,875 & 18.6 \\
1976 & 8,279 & 18.6 \\
1977 & 9,679 & 19.2 \\
1978 & 12,496 & 23.9 \\
1979 & 19,034 & 30.2 \\
1980 & 27,162 & 37.3 \\
1981 & 35,671 & 48.1 \\
1982 & 43,634 & 60.3 \\
1983 & 44,781 & 59.5 \\
1984 & 47,821 & 60.5 \\
1985 & 48,312 & 64.5 \\
1986 & 51,422 & 65.1 \\
& &
\end{tabular}

Source : Di Tella and Dornbusch, The Political Economy of Argentina, 1946-83.

${ }^{*}$ Total Debt $=$ Private + Government Debt in millions of U.S. dollars

We could have split the debt column to reflect public (government debt) and private debt but the fact is that by 1984 (the end of the last military dictatorship in 
Argentina) almost all private debt was transferred to the public sector. De Pablo and Dornbusch [1989] says that "in 1980 about half of the external debt was owed by the public sector; by 1985 that share had increased to 82 percent."

In fact, this indebtedness process had no counterpart in growth for the economy. During this period the government encouraged indebtedness as a process of 're-industrialization and modernization' of the economy with the same government being the guarantor of such debts. As we can imagine, such investments in modernization were not real investments but ways of getting foreign currency, thus contributing to the process of currency substitution and to the so called "Plata Dulce" period.

Larry Sjaastad (1989) argues that:

"During the period in question (1976-81), the external debt of Argentina increased dramatically, even when taking into account the impressive growth of international reserves in the hands of the Central Bank. That growth in reserves was, incidentally, largely a consequence of the policies that accompanied the 'Plan del 20 de Diciembre'. The combination of the liberalisation of the domestic capital market (which had begun before 1979), the opening of that market to the rest of the world, and the decision to finance much of the fiscal deficit in that market made possible an unprecedented growth of reserves." 


\subsection{CURRENCY SUBSTITUTION IN ARGENTINA}

To have an idea of the importance of currency substitution during the period 1976-1981, a transcription of Sjaastad (1989, pp. 265-66) will be useful:

"...Argentina's gross external debt increased by nearly $\$ 16$ billion during 1979 and 1980, most of it as a liability of the public sector (or guaranteed by the government). A substantial part of that increase in foreign indebtedness was, ironically, a direct consequence of the highly favourable international reserve position of the Central Bank. During the course of 1980, and perhaps even earlier, fear of an unscheduled devaluation (which resulted in extraordinary high peso interest rates on deposits as the Argentine banks struggled to maintain those deposits) began to erode the monetary base as individuals moved out of pesos and into dollars. To prevent a decline in international reserves in the face of that currency substitution, a decline that might well have produced a 'run' against the peso, the public sector borrowed heavily abroad and held the proceeds in the form of peso deposits. While this action temporarily prevented a decline in the global demand for pesos (and hence the monetary base and international reserves), it meant that external debt was rising to unprecedented levels, the bulk of that debt being a liability of the public sector. This borrowing was, of course, in 
addition to the growth in external indebtedness resulting from financing the fiscal deficit in the capital market."

But why is it that currency substitution is such an important issue in Argentina? One of the main reasons is that it creates greater inequality because not every sector in society, or not every individual in society, is able to hold or hoard the necessary amount of money that will enable him or her to command some proportion of foreign currency in the case of higher local inflation. However, in an excellent article Jacek Rostowski (1992) concludes that " . . to the extent to which inflation tax is regressive, as is claimed for example by Dornbusch, Sturzenegger and Wolf (1990), then widespread legal currency substitution will act to equalize incomes." ${ }^{18}$ This conclusion would be true if the access to foreign currency balances were to be similar for all income groups and geographical areas of the country, which is not the case of the Argentine economy and probably for other less developed countries, or if there were no costs associated with switching to foreign currency balances. Sturzenegger (1992) has concluded that "currency substitution takes place in high inflation economies, and rich people have preferential access to this technology. In our setup, this preferential access was induced by a fixed cost of currency substitution, which made this technology profitable only for sufficiently

${ }^{18}$ Jacek Rostowski (1992), p. 104. 
high levels of income."19

In fact, the cost of "getting" into foreign balances is intimately related to asymmetries due to the lack of financial and geographical integration of the country. Even legal currency substitution will not make this practice widespread, as Rostowski argues.

Rostowski argues in favor of widespread currency substitution during high inflation episodes to avoid or reduce the ". . . 'noise' affecting the information carried by relative prices."(Rostowski 1992, p.92) He shows that currency substitution helps in maintaining the level of output when inflation is high and individuals would not be able to discern whether changes in prices were due to "underlying supply and demand relationships for particular goods, or merely the result of changes in the average price level." (Rostowski 1992, p.92)

Rostowski then compares currency substitution and indexation as two ways in which highly inflationary economies adjust. He says that "both are commonly viewed as causing an acceleration of inflation, although it is sometimes admitted that they also mitigate the disruptive real effects of high inflation. Like indexation, secondary currencies facilitate inter-temporal contracts. In very high inflation contracts which are to extend over significant periods must either be indexed or expressed in a stable second currency. However, using a secondary currency for this purpose is more efficient since much indexation can only take place discretely

${ }^{19}$ Federico A. Sturzenegger (1992), p. 190. 
and the time between valorizations cannot be the same for all goods, so that relative prices vary sharply between valorizations. This is the well known Taylor effect." (Rostowski 1992, p.93)

Rostowski concludes that currency substitution should be preferred to indexation because "unlike indexation secondary currencies make it easier for relative prices at a point in time to vary in response to underlying market conditions, and for variations in relative prices to act as signals to economic actors." (Rostowski, 1992, p. 94)

Due to the absence of capital markets, or more specifically, of well established and efficient capital markets in almost every underdeveloped country, individuals are only able to hold their savings or their assets in the form of local currency. ${ }^{20}$ If this local currency is depreciating continuously (i.e., if the rate inflation is constant, and positive) then the opportunity cost of holding real monetary balances will increase continuously. Furthermore, if the government is using inflation as a tax over consumers, that is to say, if seigniorage is being collected by the government, individuals will try to hold other assets instead of local currency. This is one, or the most important reason, for currency substitution, in which individual consumers get out of local currency in order to avoid this inflation tax imposed by the government.

${ }^{20}$ This is one of the main difference between Argentina's hyperinflationary processes and that of, for example, Germany's hyperinflation in the 1920's. 
But currency substitution is intimately related to the distribution of income in many other ways. Individual agents in lower income strata will tend to have a reduced number of alternatives when faced with higher inflation than individual agents in higher levels of income. Investing in real estate has been one of the most important ways in which higher and middle income Argentines have been trying to shield themselves from the effects of higher inflation. To this issue it would be useful to bring paragraph from the case of $\mid \mathrm{srael}^{21}$ in the 1980 's:

"Even in an indexed environment, inflation causes problems with savings, too. The most salient symptom is the tendency of households to accumulate assets in the form of real estate, on the supposition that this form of wealth is better shielded from inflation. In fact, the added demand for apartments as a form of investment actually did cause their prices to inflate more rapidly. During 1979, for example, housing prices increased by 159 percent, while the consumer price index rose by 111 percent. This misallocation of resources was evident from the considerable number of empty apartments that people maintained as a hedge against inflation."22

But what is the problem of investing in real estate in a society characterized

${ }^{21}$ The similarities between the Israeli economy and the Argentine economy are constantly addressed by many authors.

${ }^{22}$ Yakir Plessner (1994), pp. 205-206. 
by a highly unequal distribution of income? The problem is that only a small percentage of the population, those who are able to hoard enough foreign currency to buy real estate through a cash transaction due to the inexistence of a credit market, will be able to 'invest' in real estate. They will be the only ones that have enough income to 'invest' in this type of venture. The situation in Argentina is similar to that of Israel in that individuals tend to buy real estate to protect themselves against inflation.

The rest of the population will have no alternative but, probably, to increase consumption before their money diminishes its value or to buy foreign currency immediately after they collect their salaries, which implies an increase in the velocity of circulation of money. This produces higher inflation without an increase in the supply of money, which produces a reduction in foreign reserves held by the country, which, at the same time, produces a pressure to devaluate the local currency. If this happens it acts like an accommodating type of policy on the part of the government, which produces what is called a 'devaluation-inflation spiral.'

Another implication of currency substitution has to do with geographical location and integration of the financial system within the country. There are only three to four cities in Argentina that could be said to be integrated to the world capital market so as to enable its citizens to effectively exchange their local currency for foreign currency. At the same time, the cost involved in shifting to a foreign currency will be higher in non-financially integrated regions of the country 
than in the case of people living in Buenos Aires or other financial centre of the country. The rest of the country, and several sectors within these big cities, will be unable of shielding themselves from increases in inflation and will be the most affected by a change in this rate.

We will see later on that theoretical models dealing with currency substitution use the assumption that individuals are "lump-sum" compensated by the government for the increased opportunity cost of holding real monetary balances. In fact we will assume later on that instead of receiving proportional ${ }^{23}$ lump-sum transfers of money, a possible assumption will be that they receive non-proportional lump-sum transfers. But we will be discussing this issue in greater detail in later chapters.

Currency substitution has become a big issue in the economic literature, and specifically when talking or analyzing the creation or the development of the European Monetary System in one side and in discussing its effects over monetary policy in highly inflationary, and underdeveloped, economic systems. To the former we could mention papers by Michael Woodford (1990), Alberto Giovannini (1991), Maurice Obstfeld (1991,1994), Philippe Weil (1991), Alessandra Casella (1990), etc. The later argument deals with currency substitution and exchange rate

${ }^{23}$ Proportional to their own holdings of real monetary balances. We will see later on that the "representative individual" assumption "imposes" these results to these models, although this "representative individual" takes these transfers as "independent" from its own real monetary holdings. 
variability and has a vast literature that began with Guillermo Calvo and Carlos Alfredo Rodríguez (1977) and continued with Liviatan (1981), Calvo (1985), Penati (1987), Engel (1989), Sturzenegger $(1991,1992)$, and finally the paper by Heng-Fu Zou (1993), just to mention some of them.

Still, we will be looking even further into the issue of currency substitution. We will argue that although real foreign monetary balances cannot be negative, the supply of foreign real monetary balances depends on the trade surplus (deficit) of the country ${ }^{24}$ and it will not be supplied 'free of charge' as is the case of domestic real monetary balances. This implicit cost of 'getting' into foreign monetary balances will have its implications on the assumptions we make on the behavior of agents and their expectations for the future ( i.e., whether there will be a trade surplus or a trade deficit).

\subsection{MISCONCEPTIONS ABOUT CURRENCY SUBSTITUTION}

While the issue of currency substitution has had a great deal of intellectual importance over the last decades, we still think that there are misconceptions about the reasons and the origins of such a phenomenon. Some of these misconceptions are discussed below.

${ }^{24}$ Other alternatives could be through financial assistance from other countries or through capital mobility in order to sustain a specific exchange rate. 


\subsubsection{Currency Substitution As A Choice Of Governments}

The fact of the matter with respect to currency substitution is not that governments decide to "introduce" an indexed currency (like in Sturzenegger, 1994) so as to reduce the rate of inflation or hyperinflation of the original currency, but that currency substitution is an alternative from the individual agent point of view, given the expectations of the future. Governments are, if anything else, reacting to a decision made by individual agents. ${ }^{25}$

Currency substitution is not being "imposed" from above by a "benevolent" government. Currency substitution is something that will be decided independently from the government by the individual consumer who distrusts of the "ability," or the "desire," or the "willingness" on the part of the government to control (hyper)inflationary processes. In fact, there has always been a direct link between institutional political disintegration and hyperinflationary processes. ${ }^{26}$

Much of the literature on currency substitution deals with the issue of the alternatives from the point of view of the government with respect to the correct rate

${ }^{25}$ Such has been the case of the Real Plan introduced in Brazil in 1994. The Convertibility Plan in Argentina is also a reaction by the government to the currency substitution phenomenon.

${ }^{26}$ Germany would be the most pathetic example of this characteristic, but Argentinas' hyperinflationary processes have had their own doses of institutional political disintegration, i.e., Isabel Perón in 1976, Galtieri-Bignone in 1982-83, and Alfonsín in 1989-90. The lack of control of the future is one of the similarities, if any, between these three events. 
of growth of the money supply. Nothing is further from the truth. Governments do not choose currency substitution as an alternative to uncontrollable inflationary processes. Quite the opposite, for these governments, currency substitution is a constraint on their ability to collect taxes by increasing the supply of money and on the independence of monetary policy.

Rogers (1992) argues that "the degree to which an economy's total transactions are conducted in U.S. dollars rather than domestic currency is referred to as 'dollarization,' a phenomenon that may be important for several reasons. When demand for dollars grows beyond the requirements of tourism and international trade, it is difficult for the monetary authority to find an appropriate definition of money and to control domestic liquidity." (Rogers 1992, p.320)

Bufman and Leiderman argue that "if the degree of currency substitution is high, small changes in the money supply would induce large changes in the exchange rate. These circumstances are likely to reduce the effectiveness of monetary policy by contracting the component of domestic liquidity over which the authorities have direct influence. Increased currency substitution may also require an adjustment of fiscal policy because of the induced reduction in the inflation-tax base. Moreover, perfect substitutability makes a multicurrency region more vulnerable to hyperinflations." This was also the conclusion put forward by Weil (1991), although we will show that imperfect substitutability between currencies do not necessarily reduce the scope for hyperinflationary solutions. We are going to 
analyze this issue further throughout this dissertation.

\subsubsection{Currency Substitution Vs. Financial Adaptation}

We are now going discuss the differences that we think exist between currency substitution and financial adaptation. ${ }^{27}$ According to Peter N. Ireland financial adaptation is a characteristic of modern economies. Sturzenegger (1992) defines "financial adaptation" as " . . an improvement in the savings or transactions technology that creates convenient alternatives to money, (which) is

a well known phenomenon in high-inflation economies." (Sturzenegger, p.179) Then, he continues saying that "there are many ways to evade the inflation tax, from using credit cards, checkable interest-bearing accounts, or simply through 'dollarization'." (Sturzenegger 1992, p.179) But, this is not true for Argentina. Currency substitution in Argentina cannot be identified with financial adaptation or with the use of "credit cards," "checkable interest-bearing accounts" which is a characteristic of "commercial progress. . . " However, it can be identified with producing similar consequences for an economic system due to the ". . generally higher, average velocity of circulation of the medium of exchange, . . " in words of Peter N. Ireland. ${ }^{28}$

${ }^{27}$ Sturzenegger (1992) uses both terms interchangeably.

${ }^{28} \mathrm{Again}$ refer to pages 4 and 5 in Section 1.1. 
In fact, the private banking system, as well as financial institutions (Diners Club, Visa, Master Card, American Express, etc.) as we know them in the United States (as providers or suppliers of alternative mediums of exchange), were greatly transformed and/or ceased to exist in Argentina during highly inflationary processes. At the beginning of the 1980's supermarkets started to accept credit cards for purchases. However, this policy lasted only for a few months because people started to use them to minimize their losses due to monthly inflation above $10 \%$. Consumer credit was nonexistent in Argentina for these periods.

Then, the use of credit cards, which is one of the "ways" in which financial adaptation shows up in an economy was not the characteristic of the Argentine situation.

People shifted to holding foreign monetary balances, specially U.S. dollars, to minimize the effects of inflation. However, U.S. dollars were not the only substitutes to domestic monetary balances. While in Russia it has been argued that people opted to hold commodity goods like vodka, in Argentina individuals were willing to hold, at some periods, "cospeles del subterráneo" (subway tokens) which represented a fixed amount of service. ${ }^{29}$ Each token represented a trip in the subway in any direction and with "unlimited millage."130 They also used to hold

${ }^{29}$ We could say that these subway tokens were "backed" or "indexed." See Obstfeld and Rogoff (1983), Sturzenegger (1992), and Weil (1991). We would see this condition latter on in the dissertation.

${ }^{30}$ Actually, they were limited only to the extent that subways routs and destinations were themselves limited. 
telephone tokens until the government-owned enterprise decided to reduce the amount of time that each telephone communication lasted (a change in the "impulsos," as is called in Argentina) with each token.

An example of financial adaptation in Argentina could be characterized by the following example. Automobile purchases by consumers were characterized by something called "Plan de Ahorro Previo" (the most notorious one was that of Ford Motors Argentina, called "Plan Rombo," but every car manufacturer had a similar program in place; the same thing happened with almost every durable and/or expensive good). Of course high income individuals could buy these durable goods at any moment because they held dollars in their portfolios. However, this was created to expand their consumer market.

These programs translated into something like an "anticipated savings plan," (henceforth ASP) which could be compared with some type of 'lay-a-way' plan in the United States. The most important difference between this ASP in Argentina and a normal 'lay-a-way' plan in the United States is that the former plan was a highly sophisticated group plan conceived as a way of increasing the consumer base or to increase the potential market by helping low income consumers.

It was also put in place not only to increase their consumer market, which was very small, but it also worked as an insurance to avoid excess supply of automobiles during periods of high inflation and high uncertainty. It was also a way of minimizing high fluctuations in output characteristic of high inflation episodes. 
This plan consisted of the following scheme: consumers were asked to participate as members with other consumers to start paying monthly installments toward the purchase of the car. Monthly instalments were not necessarily fixed, rather, they were indexed to inflation. Each participant in this group was going to make monthly payments for a period, let us say, of five years, ${ }^{31}$ after which they were assured to receive their car. This could be one reason that total dollarization has not been observed in Argentina, even with extremely high levels of monthly inflation.

Then we could say that Financial Adaptation could prevent full dollarization from taking place in a country. At the same time, Financial Adaptation is different from currency substitution. These concepts are not interchangeable.

Why were these programs so common and successful? Furthermore, why were they so persistent, even in highly inflationary periods? There were two main reasons for this outcome. First, these customers were unable to purchase these cars in an "all cash" transaction. ${ }^{32}$ They were mainly low to middle income individuals, and mostly middle income individuals. Second, there were incentives put forward by the auto manufacturers or by the administrators of the plan that

${ }^{31}$ Of course, the amount of years depended in the type of good consumers were purchasing. TV sets, refrigerators, etc., had shorter periods of prepayment.

${ }^{32} \mathrm{Cars}$ were being sold on a cash basis due to the non-existence or lack of consumer credit. 
consisted in giving "away" several cars per year. ${ }^{33}$ This ASP included an incentive. The incentive was a raffle ${ }^{34}$ by which participants had the opportunity (if luck was on their side) of "winning" a car. The raffle was between the participants in this plan, and most importantly, it depended on their good standing within the plan, i.e., having paid all installments to date. Of course, with the commitment of continuing the payments until those five years had elapsed. So participants could wait five years to "get" their car or, if they were lucky enough, get the car some day before five years.

We could say that the above mentioned financial adaptation process also prevented this economy to dollarize completely, even in high inflation or hyperinflationary processes. This could be one of the financial instruments that have prevented complete dollarization in Argentina. In fact, we could argue that financial adaptation is one of the major reasons for full dollarization not to have occurred, even in the presence of hyperinflationary situations.

Currency substitution, as Calvo (1985), Sturzenegger (1992), etc. argues is related to an "improvement in the savings or transactions technology." However, inflation creates many problems with the efficiency of these transaction technologies. We could find some extreme cases in Argentina. Bars or pubs (confiterias), with pool tables, did not change their pool tables "technology" so as

\footnotetext{
${ }^{33}$ The number of cars depended on the surplus production for each year and some minimum number of cars to be given out each year stipulated by the ASP.

${ }^{34} \mathrm{Ag}$ ain the time span depended on the good being sold.
} 
to use tokens to run their pool tables machines. Consumers, instead had to buy "quarters" (U.S. quarters) to be able to play pool. Consumers could buy a United States "quarter" (25ф) for the equivalent of, let's say, $\$ 1.50$ dollars in Argentinean pesos to be able to play a game of pool!

Then, by the above example, financial adaptation does not mean currency substitution. In fact, financial adaptation produced the use of new technologies (like the pool tables payment mechanism mentioned above) but using the domestic currency to conduct the transaction. Thus, currency substitution cannot be identified with financial adaptation, and in fact, financial adaptation could be one of the major causes for full dollarization not to have taken place in Argentina.

\subsubsection{Currency Substitution Vs. Capital Flight}

Another misconception about currency substitution is that of identifying it with capital flight, or at least for arguing that currency substitution is indistinguishable from the capital flight phenomenon. This is incorrect in the sense that even without earning a return on those balances, individuals will still choose to hold this type of balances in their portfolios, or in their banks' safe deposits. Or they may hold these balances because of the inexistence of efficient capital markets, credit markets, or efficient banking systems.

In fact, Argentines will hold foreign monetary balances, U.S. dollars, even 
knowing that with a positive dollar inflation rate the purchasing power of their dollars will be diminished.

\subsubsection{Dollarization Vs. Currency Substitution}

The last issue in this section has to do with the difference between dollarization and currency substitution. This point has been put forward by Calvo and Végh (1992). They argue that "...casual evidence suggests that, in high inflation countries, foreign currency is first used as a store of value or unit of account and only later as a medium of exchange. In other words, currency substitution is normally the last stage of the dollarization process."(Calvo and Végh 1992, p. 4)

We will see all along this dissertation that dollarization is indeed different from currency substitution, and that we cannot analyze the effects of currency substitution on the domestic inflation rate by looking only at the process of dollarization taking place in Argentina. In fact, dollarization is a process that takes time, that is to say, it spans over a long period of time, and it depends fundamentally on the exchange rate and its relationship with the current account (or the balance of payments if capital is not mobile), while currency substitution can be analyzed at a specific point in time and depends on legal or institutional requirements of a specific country and in the availability of foreign monetary balances in the possession of individuals. 


\section{CHAPTER 3}

\section{DEVALUATION: WITH ENDOGENOUS RATES OF TIME PREFERENCE AND HETEROGENEOUS AGENTS}

\subsection{INTRODUCTION}

In this chapter we will use the same assumptions used by Calvo's 1981 article but in the context of endogenous rates of time preference used by Obstfeld's 1990 article. We, as Calvo does, are going to examine the cases where either the price level jumps (i.e. a devaluation), or there is a change in the rate of inflation (i.e. a change in the rate of devaluation), letting money supply be determined by the balance of payments.

The results are, as in Calvo (1980), that a devaluation always improves the balance of payments (if seignorage from inflation is returned to the public) while an increase in the rate of devaluation has the opposite effect, i.e. it deteriorates the balance of payments. However, differences arise due to the fundamental difference in the nature of our model, which assumes endogenous rates of time preference. The rate of time preference will be smaller after an increase in the rate of devaluation, which implies that consumers will be less impatient under endogenous that under fixed rates of time preference. This is a consequence of the assumption 
that there is no capital mobility. ${ }^{1}$

\subsection{ASSUMPTIONS OF THE MODEL 2}

As it was said in the introduction, we are going to make the same assumptions that those of Calvo's (1981) so be advised that this is just an enumeration of these assumptions and are taken directly from that paper. It will be just a quick refresher.

In this model, $c$ and $m$ stand for consumption and real (domestic) monetary balances; $m=\frac{M}{P}$ where $M$ and $P$ are domestic nominal money holdings and the price level respectively.

We assume a small open economy which implies that international prices and exchange rate between foreign currencies remain constant over time, allowing us to identify $\mathrm{P}$ with the exchange rate (i.e., the relative price) of domestic currency in terms of some other given currency.

Each family (representative consumer ${ }^{3}$ ) receives y units of output per unit of time and the only available asset is domestic money (this assumption implies no international capital mobility).

${ }^{1}$ See Obstfeld (1981) where he studies the case when there is perfect capital mobility. With perfect capital mobility, the world interest rate is given and equal to the endogenous rate of time preference.

${ }^{2}$ These assumptions are taken directly from Calvo (1981), pp. 165-172.

${ }^{3}$ We will change this assumption latter on in this chapter. 
The inflation rate $\pi=\frac{\dot{P}}{P}=$ rate of devaluation. $\tau=$ government lump-sum transfers. We assume that $\tau$ is chosen so as to compensate for the 'maintenance' or depreciation cost of holding money, and that it takes the form of money transfers.

Along an equilibrium path,

$$
\text { balance of payments at time } t \equiv y-c
$$

Therefore, if $\mathrm{M}^{\mathrm{s}}$ denotes nominal supply of money, we have

$$
\dot{M}^{s}=(y+\hat{\tau}-\hat{c}) P \equiv \hat{M}
$$

where 'hat' indicates equilibrium solutions and

$$
\hat{\tau}=\pi \hat{m}
$$

i.e. the flow supply of money is determined by the accumulations of reserves

$$
(y-\hat{c}) P
$$

plus the rate of (what is usually called) domestic credit

$$
\hat{\tau} P
$$

By (3.2), (iii), and (ii), we get

$$
\dot{m}=y-\hat{c}
$$

And finally, the consumer is assumed to know the paths of $P$ and $\tau$ but takes them as exogenous and independent of its individual behavior. This amounts to assuming Perfect Foresight and Perfectly Competitive Markets. We will also assume that $\pi$ (the rate of inflation) will be constant after $t=0$. 


\subsection{THE MODEL ${ }^{4}$}

We are considering a representative consumer which is infinitely lived. Each consumer is assumed to be maximizing the following utility function:

$$
U[C(0), m(0)]=\int_{0}^{\infty}-\exp [-z(t)] \exp (-r t) d t
$$

subject to

$$
\dot{m}=y+\tau-\pi m-c
$$

and

$$
\dot{z}(t)=u[c(t), m(t)]-r ; \quad z(0)=0
$$

The Current-value Hamiltonian for the individual maximization problem is

$$
\begin{gathered}
H(c, m, z, \tilde{q}, \tilde{\omega}) \\
-\exp (-z)+\tilde{q}[y+\tau-\pi m-c]-\tilde{\omega}[u(c, m)-r]
\end{gathered}
$$

and gives us, in addition to (3.2) and (3.3), the necessary conditions

${ }^{4}$ This model is taken from Obstfeld (1990), pp. 45-75. The only difference with Obstfeld's original model is that now real monetary balances are included alongside with consumption in the utility function. 


$$
\begin{gathered}
u_{c}(c, m) \omega+q=0 \\
\dot{q}=q[u(c, m)+\pi]+\omega u_{m}(c, m) \\
\dot{\omega}=u(c, m) \omega+1
\end{gathered}
$$

where we have used the simplification that [Arrow and Kurtz (1970), and Obstfeld (1990)]

$$
q \equiv \tilde{q} \exp (z) ; \omega \equiv \tilde{\omega} \exp (z)
$$

The transversality conditions sufficient for optimality [Arrow and Kurtz(1970), and Obstfeld (1990)] are

$$
\lim _{t \rightarrow \infty} \tilde{q} \exp (-r) \geq 0 ; \lim _{t \rightarrow \infty}-\tilde{\omega} \exp (-r) \geq 0
$$

and

$$
\lim _{t \rightarrow \infty} \tilde{q} m \exp (-r)=0 ; \lim _{t \rightarrow \infty}-\tilde{\omega} m \exp (-r)=0
$$

In order to calculate the rate of time-preference we use the definition of the Volterra derivative, $D_{V}$ which is the quantity

$$
\begin{gathered}
\left.D_{V}[U C(0), m(0)], c(t), m(t)\right] \exp [-z(t)-r t]= \\
{\left[-u_{c}[c(t), m(t)] \omega(t)\right] \exp [-z(t)-r t]}
\end{gathered}
$$


which is equation (3.5), which measures the lifetime marginal utility at $t=0$ from a local increase at any point $t \geq 0$ along the path $C(0), m(0)$. It is the rate of decrease in the marginal utility of consumption and real money balances along a locally constant consumption and real money balances path. Then, using (3.5) the rate of time preference, denoted by $\rho$, is (minus) the logarithmic time derivative of

$$
\begin{gathered}
\mathrm{D}_{\mathrm{V}}\{\mathrm{U}[\mathrm{C}(0), \mathrm{m}(0)], \mathrm{c}(\mathrm{t}), \mathrm{m}(\mathrm{t})\}: \\
\rho=-\left.\frac{d}{d t} \log D_{V}[U[C(0), m(0)], c(t), m(t)]\right|_{\dot{c}(t)=\dot{m}(t)=0}
\end{gathered}
$$

Using equation (3.5) then, we are able to calculate the rate of time preference for the consumer using the Volterra derivative, $D_{V}$ :

$$
\rho(c, m, \omega)=u(c, m)\left[1+\frac{[\omega+1 / u(c, m)]}{\left[-\omega u_{c}(c, m)\right]} u_{c}(c, m)\right]>0
$$

which is similar to the rate of time preference derived by Obstfeld in his 1990 article, but, of course, with money as an argument in the utility function.

At steady-state with constant consumption $(\bar{c})$ and constant money $(\bar{m})$, we then have the following:

$$
\omega=\bar{\omega}=-\frac{1}{u(\bar{c}, \bar{m})}
$$


which implies, in our case that (10) will be equal to

$$
\rho(\bar{c}, \bar{m}, \bar{\omega})=u(\bar{c}, \bar{m})
$$

Let us look now at the solution for consumption using equation (3.5). Time differentiation of (3.5) shows that

$$
-u_{c c}(c, m) \dot{c} \omega-u_{c m}(c, m) \dot{m} \omega-\dot{\omega} u_{c}(c, m)=\dot{q}
$$

or rearranging

$$
\left[-u_{c c}(c, m) \omega\right] \dot{c}+\left[-u_{c m}(c, m) \omega\right] \dot{m}-\dot{\omega} u_{c}(c, m)=\dot{q}
$$

Using (3.7) to eliminate $\dot{\omega}$ and (3.6) to eliminate $\dot{q}$ and then applying (3.5) to eliminate $q$ and after some manipulation we get:

$$
\dot{c}=\sigma\left[\rho(c, m, \omega)+\pi-\frac{\left[u_{m}(c, m) \omega\right]}{\left[u_{c}(c, m) \omega\right]}-\mu \dot{m}\right]
$$

where

$$
\sigma=\frac{\left[u_{c}(c, m) \omega\right]}{\left[u_{c c}(c, m) \omega\right]}<0
$$

and 


$$
\mu=\frac{\left[u_{c m}(c, m) \omega\right]}{\left[u_{c}(c, m) \omega\right]}>0
$$

where $\sigma$ (Epstein 1987, p.76) "...measures the effect of consumption growth on the proportional rate of change of 'current valued' marginal utility..." In our case, however, marginal utility of consumption "...is no longer uniquely related to $c$ because the marginal utility of $\mathrm{c}$ depends in general on $\mathrm{m}$. " (Blanchard and Fischer 1989, p. 189). Then, given $U$, the higher is $-(1 / \sigma)$ the stronger is the desire to smooth the consumption and money holdings profile.

\subsection{RESULTS OF THE MODEL}

As we argued at the beginning, the results are similar to those of Calvo 1981.

We are then left with three differential equations

$$
\begin{gathered}
\dot{\omega}=u(c, m) \omega+1 \\
\dot{c}=\sigma\left[\rho(c, m, \omega)+\pi-\frac{\left[u_{m}(c, m) \omega\right]}{\left[u_{c}(c, m) \omega\right]}-\mu \dot{m}\right]
\end{gathered}
$$

and

$$
\dot{m}=y-c
$$


Using these three equations and substituting (3.17) into (3.14) we get a system of three differential equations in $c, m$ and $\omega$ :

$$
\begin{gathered}
\dot{\omega}=u(c, m) \omega+1 \\
\dot{c}=\sigma\left[\rho(c, m, \omega)+\pi-\frac{\left[u_{m}(c, m) \omega\right]}{\left[u_{c}(c, m) \omega\right]}-\mu(y-c)\right] \\
\dot{m}=y-c
\end{gathered}
$$

At steady state we have

$$
\begin{gathered}
\bar{\omega}=-\frac{1}{u(\bar{c}, \bar{m})} \\
u(\bar{c}, \bar{m})+\pi=\frac{\left[u_{m}(c, m) \omega\right]}{\left[u_{c}(c, m) \omega\right]}
\end{gathered}
$$

and

$$
y=c
$$

$$
\left[\begin{array}{c}
\dot{\omega} \\
\dot{c} \\
\dot{m}
\end{array}\right]=\left[\begin{array}{ccc}
u(c, m) & F & G \\
\delta & u(c, m)+\pi & \beta \\
0 & -1 & 0
\end{array}\right] \cdot\left[\begin{array}{c}
\omega-\bar{\omega} \\
c-\bar{c} \\
m-\bar{m}
\end{array}\right]
$$


where

$$
\begin{gathered}
F=\left[u_{c}(c, m) \omega\right]>0 \\
G=\left[u_{m}(c, m) \omega\right]>0 \\
\delta=-\frac{1}{\left[u_{c c}(c, m) \omega\right]}\left[u_{m}(c, m)-u_{c}(c, m) \pi\right]<0 \\
\beta=-\frac{1}{u_{c c}}\left[\left[-u_{c m} \omega\right][u(c, m)+\pi]+u_{m m} \omega\right]<0
\end{gathered}
$$

For stability we need the trace of the principal matrix to be positive, so that at least one eigenvalue is always positive. The trace of the principal matrix is:

$$
\text { trace }=2 u(c, m)+\pi>0
$$

which is definitely positive.

The sign of the determinant is negative:

$$
\text { determinant }=G \delta+u(c, m) \beta<0
$$

We have also used the following signs on the functions: 


$$
u(c, m)>0 ; u_{c}(c, m)>0 ; u_{m}(c, m)>0 ; u_{c c}(c, m) \leq 0 ; u_{m m}(c, m) \leq 0 ; u_{c m}(c, m)>0
$$

And further, we are assuming that consumption and real money balances are complementary in providing utility, then

$$
-\left[-u_{c m}(c, m) \omega\right]>0
$$

These assumptions mean that [Obstfeld, 1990]: $u_{c m}$ is assumed to be twice continuously differentiable. The discount rate $u_{c m}$ is taken to be strictly positive. With the added assumption that money and consumption are complementary in utility.

Now we are going to proceed with the conclusions of the model. Then, since an unanticipated devaluation is equivalent to an initial downward jump in initial $m$, it trivially follows that such a policy will always improve the balance of payments (if the inflation tax is returned to the consumer) just as in Calvo 1981.

If, on the other hand, we have an increase in the rate of devaluation, i.e., an increase in $\pi$. Taking the partial derivative with respect to inflation we get the following result:

$$
\frac{\partial \dot{c}}{\partial \pi}=\sigma<0
$$


from equation (19). Then the new steady state will be characterized by having the same level of consumption ${ }^{5}$ and a lower level of real monetary balances, the latter reflecting the larger opportunity cost of holding real monetary balances due to the increase in the rate of inflation.

By linearizing the system in the neighborhood of the steady state we can also look at the dynamics of the model. Then linearizing the three differential equations around steady state we have:

$$
\begin{aligned}
& \omega(t)-\bar{\omega}=z_{1} A e^{\lambda_{1} t} \\
& c(t)-\bar{c}=z_{2} A e^{\lambda_{1} t} \\
& m(t)-\bar{m}=A e^{\lambda_{1} t}
\end{aligned}
$$

where

$$
\begin{gathered}
A=\left(m_{0}-\bar{m}\right)>0 \\
z_{1}=\frac{\left[z_{2} F+G\right]}{\left[u(c, m)-\lambda_{1}\right]}>0
\end{gathered}
$$

${ }^{5}$ Remember that this is due to equation (20) by which income is equal to consumption at steady state. 
and

$$
z_{2}=-\lambda_{1}>0
$$

By looking at equation (3.25.2) we can see that an increase in the rate of devaluation (an increase in $\pi$ ) produces an increase in consumption on impact and at the same time a process of substitution between consumption and real monetary balances in which the latter declines monotonically when $\pi$ increases. Real monetary balances cannot change on impact in this model because money is a state variable. They will change (decrease to be more precise) across steady states in a monotonic fashion. Let us see how the graphs of these variables will look like.

Figure 3.1 shows that at time $t$, when there is an increase in the rate of devaluation (an increase in the rate of inflation), consumption increases on impact to $c_{t}$ and then decreases to its constant level $\bar{c}$. The increase in consumption can come only from a decrease on the level of real monetary holdings by the representative consumer, and at the aggregate or country level, by a deterioration in the balance of payments. 


\section{Figure 3.1}

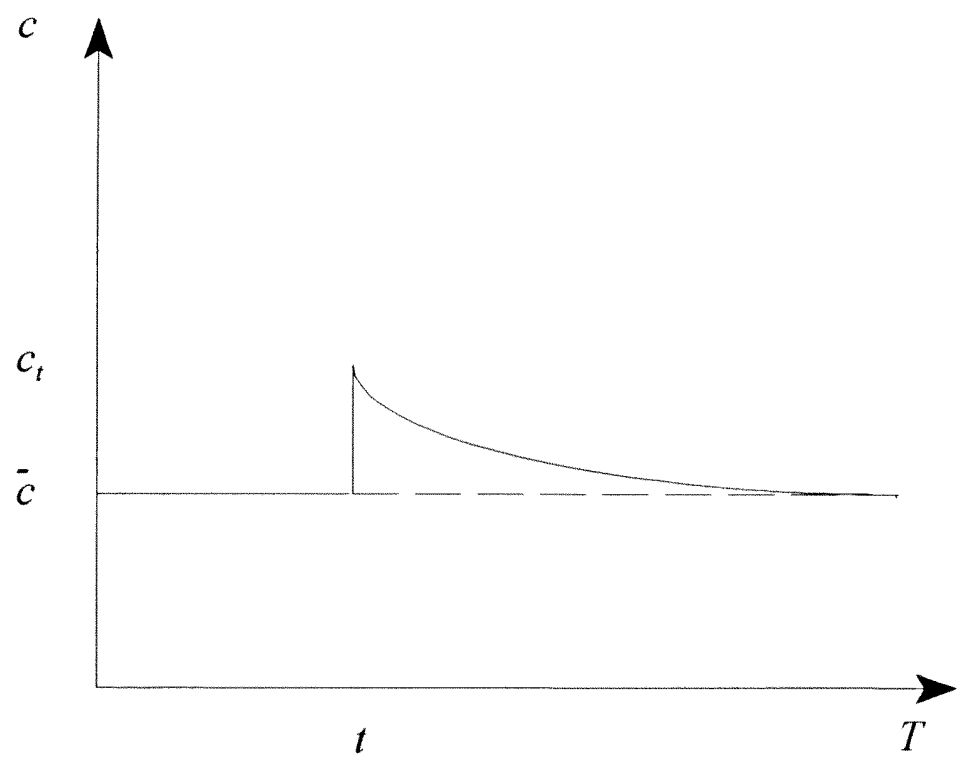

As we said before, real monetary balances decrease monotonically towards its new (lower) level in the new steady state. Money cannot jump instantaneously to accommodate the change in the devaluation or inflation rate so it will only change monotonically through time as showed by the following graph.

In Figure 3.2 we see how real monetary balances change at time t due to the increase in the rate of devaluation (rate of inflation). Since real monetary balances cannot change immediately to the new steady state value (remember that the money supply is given by the balance of payments) the increase in consumption by the representative consumer is due to the fact that individuals are running down 
their real monetary balances, or in this model, their savings (i.e., their wealth).

Figure3.2

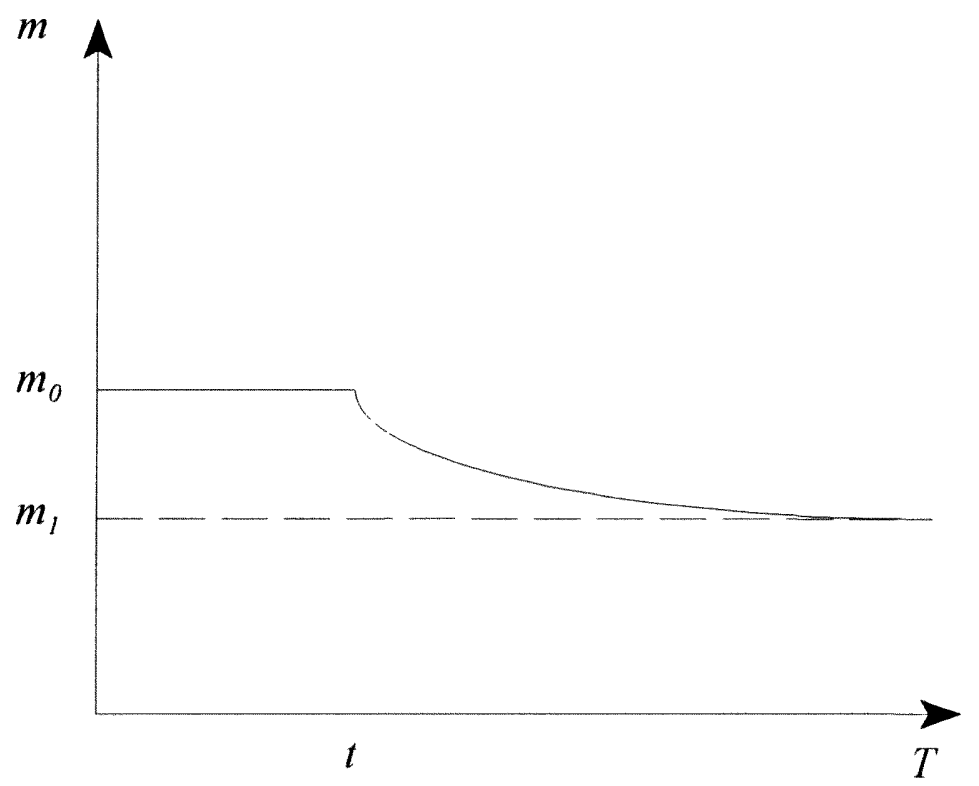

But what happens to lifetime welfare $\omega$, for this representative individual? By looking at equation (3.25.1) we see that lifetime welfare decreases. Since agents get utility by holding real monetary balances, there is a reduction in these real monetary balances as a reflection of the higher opportunity cost of holding those balances. Graphically we have the following figure 
Figure 3.3

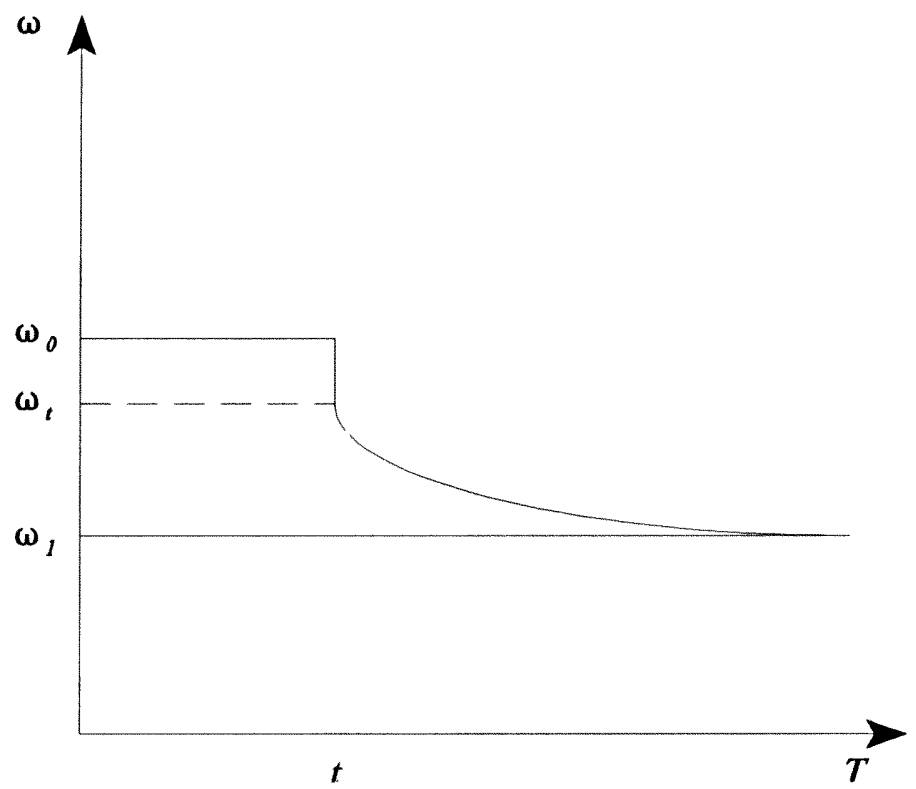

What happens in the new steady-state? Real monetary balances will be lower than in the original steady-state, due to the higher opportunity cost of holding real monetary balances, and because from (3.19) we get

$$
\begin{gathered}
u(\bar{c}, \bar{m})+\pi=u_{m}(c, m) u_{c}(c, m)^{-1} \\
u_{m}(c, m) d m+d \pi=\frac{u_{m m}(c, m)}{u_{c}(c, m)} d m-\frac{u_{c m}(c, m)}{u_{c}(c, m)^{2}} d m
\end{gathered}
$$




$$
d \pi=\left[\frac{u_{m m}(c, m)}{u_{c}(c, m)}-\frac{u_{c m}(c, m)}{u_{c}(c, m)^{2}}-u_{m}(c, m)\right] d m
$$

then

$$
\frac{d m}{d \pi}<0
$$

\subsection{HETEROGENEOUS AGENTS}

Next we are going to look at what happens when we introduce heterogeneous consumers instead of a representative consumer. So we are going to rewrite the equations of the model (or at least those that will help us to show the different responses) using subscripts (or superscripts when we have partial derivatives) to differentiate between individuals. The case of two individuals will be enough to demonstrate our point although it will carry over to $\mathrm{N}$ individuals as well. The stability of the model, that of being saddle path stable, carry over from the representative consumer case.

Let's rewrite the equations needed to conduct this analysis just for ease of manipulation but now introducing subscripts to account for heterogeneous consumer.

$$
\dot{m}_{1}=y_{1}-\pi m_{1}+\theta \sigma\left(m_{1}+m_{2}\right)-c_{1}
$$




$$
\begin{gathered}
\dot{m}_{2}=y_{2}-\pi m_{2}+(1-\theta) \sigma\left(m_{1}+m_{2}\right)-c_{2} \\
-u_{c}^{i}(c, m) \dot{\omega}_{i}=q_{i} \\
\dot{q}_{i}=q_{i}\left[u_{i}\left(c_{i}, m_{i}\right)+\pi\right]+\omega_{i} u_{m}^{i}\left(c_{i}, m_{i}\right) \\
\dot{\omega}_{i}=u_{i}\left(c_{i}, m_{i}\right) \omega_{i}+1
\end{gathered}
$$

In long-run equilibrium with constant consumption we have also

$$
\omega_{i}=\bar{\omega}_{i}=-\frac{1}{u_{i}\left(\bar{c}_{i}, \bar{m}_{i}\right)}
$$

where overbars denote the steady-state levels of the variables. This last equation implies that

$$
\begin{gathered}
\bar{\rho}_{i}=\bar{\rho}_{i}\left(\bar{c}_{i}, \bar{m}_{i}, \bar{\omega}_{i}\right)=u_{i}\left(\bar{c}_{i}, \bar{m}_{i}\right) \\
\dot{c}_{i}=\sigma_{i}\left[\rho_{i}\left(c_{i}, m_{i}, \omega_{i}\right)+\pi-\frac{u_{m}^{i}\left(c_{i}, m_{i}\right) \omega_{i}}{\left.u_{c}^{i}\left(c_{i}, m_{i}\right) \omega_{i}\right]}-\mu_{i} \dot{m}_{i}\right] \\
y_{1}=c_{1}+(1-\theta) \sigma m_{1}-\theta m_{2}
\end{gathered}
$$




$$
y_{2}=c_{2}-(1-\theta) \sigma m_{1}+\theta m_{2}
$$

where $\theta$ is the proportionality parameter for lump-sum transfers. It takes values from 0 to 1 . That is to say, $0 \leq \theta \leq 1$.

The idea now is to look at the effects of an unexpected change in the rate of devaluation in the case that we have one individual which receives more than proportional $^{6}$ real monetary transfers and some consumers receive less than proportional real monetary transfers. ${ }^{7}$

We will see here that an unexpected change in the rate of devaluation (rate of inflation) will affect the long-run level of consumption, due to the fact that $y_{i}$ is no longer equal to $c_{i}$ at steady state and in fact, the level of consumption of each agent will depend directly on the level of inflation and on the amount of lump-sum transfers.

\subsection{REDISTRIBUTION THROUGH LUMP-SUM TRANSFERS}

We are using the case of Argentina just as a "benchmark" for the case in

${ }^{6}$ More than proportional to their own real monetary holdings. Remember that before we were assuming that the representative individual received proportional real monetary lump-sum transfers.

${ }^{7}$ Another difference that could have been assumed between individuals is that they differed in their rate of time preference, or in their degree of impatience. However, this issue will not be pursued here. 
which there is an "omnipresent" government with a huge position in the production market and with non-traditional, highly sectorial mechanisms of income distribution (redistribution). Although the Argentinean experiment of redistribution of income was more through the production and distribution of goods and services, we are assuming, just for this example, that this redistribution scheme was through lumpsum transfers from the government. ${ }^{8}$ Penati $(1987$, p. 251$)$, in a somewhat different model has shown that "the impact of an increase in the inflation tax on private consumption, real balances and the real exchange rate may [be] indistinguishable from that of an increase in government expenditure on non-traded goods." This is one of the reasons why we are assuming that redistribution takes place through lump-sum monetary transfers.

${ }^{8}$ Although Argentina is being used as a "benchmark" for similar situations in the rest of the Latin American countries (i.e., highly unequally distributed income and underdeveloped or semi-industrialized countries), there are basic differences within these group of countries. For example, in comparing Argentina with Chile we have to realize that even though they may share the above characteristics, they differ fundamentally in the degree of political mobilization in relation to the degree of institutionalization. Political mobilization (read also economic mobilization) in Argentina has normally outpaced, political mobilization in Chile (although there was an exception for the case of Chile during the Allende government) making it much more difficult for the government in Argentina to avoid sectoral redistributive schemes.

For an excellent discussion on the relationship between political mobilization versus institutionalization (or what has been called "mass praetorianism") see Samuel P. Huntington in Political Order in Changing Societies, Yale University Press, New Haven and London, 1968. 


\subsection{RESULTS WITH HETEROGENEOUS CONSUMERS AND NON- PROPORTIONAL LUMP-SUM TRANSFERS}

The basic dynamics of saddle path stability of the system remain the same. The differences will be given now by the fact that consumers that receive less than proportional lump-sum taxes will be "benefited" by increases in the rate of devaluation (in the rate of inflation) and consumers that receive more than proportional lump-sum transfers will be worst off if inflation increases.

To see this let us look at the comparative statics of the model. In order to do that we are again assuming that we are at steady-state, then the system of equations is given by

$$
\begin{gathered}
u_{i}\left(c_{i}, m_{i}\right)+\pi-\frac{u_{i}^{m}\left(c_{i}, m_{i}\right)}{u_{i}^{c}\left(c_{i}, m_{i}\right)}=0 \\
y_{1}=c_{1}+(1-\theta) \sigma m_{1}-\theta m_{2} \\
y_{2}=c_{2}-(1-\theta) \sigma m_{1}+\theta m_{2} \\
u_{i}\left(c_{i}, m_{i}\right) \omega_{i}+1=0
\end{gathered}
$$

Totally differentiating system (3.34.1)-(3.34.3) we have the following results 
which include the determinant of the matrix:

$$
\Delta=u_{1} u_{2}[B D-A D(\sigma-\sigma \theta)-B C \sigma \theta]>0
$$

where

$$
\begin{aligned}
& A=\left[-u_{c_{1}}+\frac{u_{m_{1} c_{1}}}{u_{c_{1}}}-\frac{u_{m_{1}} u_{c_{1} c_{1}}}{\left(u_{c_{1}}\right)^{2}}\right]>0 \\
& B=\left[-u_{m_{1}}+\frac{u_{m_{1} m_{1}}}{u_{c_{1}}}-\frac{u_{m_{1}} u_{m_{1} c_{1}}}{\left(u_{c_{1}}\right)^{2}}\right]<0 \\
& C=\left[-u_{c_{2}}+\frac{u_{m_{2} c_{2}}}{u_{c_{2}}}-\frac{u_{m_{2}} u_{c_{2} c_{2}}}{\left(u_{c_{2}}\right)^{2}}\right]>0 \\
& D=\left[-u_{m_{1}}+\frac{u_{m_{2} m_{2}}}{u_{c_{2}}}-\frac{u_{m_{2}} u_{m_{2} c_{2}}}{\left(u_{c_{2}}\right)^{2}}\right]<0
\end{aligned}
$$

Then we get the following results:

$$
\frac{d c_{1}}{d \sigma}=\frac{\left[B D\left([\theta-1] m_{1}+\theta m_{2}\right)-D(1-\theta) \sigma+B \sigma \theta\right]}{\Delta}
$$

which will be greater or less than zero depending on the transfer parameter $\theta$. 
The same is true for the second agent:

$$
\frac{d c_{2}}{d \sigma}=\frac{\left[B D\left([1-\theta] m_{1}-\theta m_{2}\right)+D(1-\theta) \sigma-B \sigma \theta\right]}{\Delta}
$$

Then the level of consumption in the new steady state depends on the level of transfers received by each agent. Let us say that agent one gets higher than proportional lump-sum transfers, then agent one will have a higher level of consumption on the new steady state. At the same time, agent two will have a lower level of consumption at the new steady state. That is to say, agent two is negatively affected by an increase in the inflation rate and by the redistribution of income through non-proportional lump-sum transfers.

The results for welfare are the following:

$$
\frac{d \omega_{1}}{d \sigma}=\frac{\omega_{1}\left[u_{c_{1}}\left(B D\left[\alpha m_{1}-\theta m_{2}\right]+D \alpha \sigma-B \sigma \theta\right)-u_{m_{1}}\left(D+A D\left[\alpha m_{1}-\theta m_{2}\right]-\sigma \theta[A+C]\right)\right]}{u_{1}[B D-A D \alpha \sigma-B C \sigma \theta]}
$$

where $\alpha=(1-\theta)>0$.

For agent two we have the following:

$$
\frac{d \omega_{2}}{d \sigma}=\frac{\omega_{2}\left[u_{c_{2}}\left(B D\left[-\alpha m_{1}+\theta m_{2}\right]+D \alpha \sigma+B \sigma \theta\right)-u_{m_{2}}\left(B+B C\left[\alpha m_{1}-\theta m_{2}\right]-\alpha \sigma[A+C]\right)\right]}{u_{2}[B D-A D \alpha \sigma-B C \sigma \theta]}
$$


where now $-\alpha=(\theta-1)<0$.

These results are not easy to analyze. However, it will be fair to say that since agent one increases consumption from the original steady state to the new steady state, that welfare of agent one will be higher in the new steady state. The opposite will be true for agent two. Since consumption for agent two is lower in the new steady state than in the original, welfare of agent two will probably decrease in the new steady state.

Both agents will suffer, nevertheless, a decrease in their wealth because of the higher opportunity cost of holding real monetary balances. However, for those individuals that receive more than proportional real monetary transfers, an increase in the rate of inflation will improve their levels of consumption and probably, welfare, while wealth will decrease. For those agents that receive less than proportional real monetary transfers, the same increase in the rate of inflation will decrease their consumption, their welfare and their level of wealth in the new steady state. However, wealth (that is savings in our case) will be relatively higher for those agents that receive more than proportional real monetary balances.

Let us see now the results for real monetary holdings:

$$
\frac{d m_{1}}{d \sigma}=\frac{\left[D+A D\left([1-\theta] m_{1}-\theta m_{2}\right)-A \sigma \theta-C \sigma \theta\right]}{[B D-A D(1-\theta) \sigma-B C \sigma \theta]}<0
$$

It is interesting to note that there is a possibility for this result to be positive, 
that is to say, agent one will increase real monetary balances in the new steady state. This outcome would be possible if lump-sum transfers are big enough so as to make the second term in the numerator bigger than the other terms. However, it will be fair to say that this result is negative due to the increase in the opportunity cost of holding real monetary balances.

For agent two the result is the following:

$$
\frac{d m_{2}}{d \sigma}=\frac{\left[B-B C\left([1-\theta] m_{1}-\theta m_{2}\right)-(A+C)(1-\theta) \sigma\right]}{[B D-A D(1-\theta) \sigma-B C \theta \sigma]}<0
$$

Agent two will definitely reduce its monetary holdings in the new steady state, as shown by the previous equation, where all the terms in the numerator are negative if we assume that agent one receives more than proportional lump-sum transfers.

Again, the country will experience a deterioration in the balance of payments due to the increase in the rate of inflation.

\subsection{CONCLUSION}

We have shown that an increase in the rate of devaluation (in the rate of inflation) produced a deterioration in the balance of payments for a country when capital is 
immobile. ${ }^{9}$ Furthermore, we also showed that the rate of time preference will be lower in the new steady state because of the fact that agents are holding lower monetary balances with a constant level of consumption. That meant that agents had become less impatient due to the increase in the rate of inflation and to the fact that they were lump-sum compensated by the effects of the higher opportunity cost of holding real monetary balances.

We were also able, in this model, to look at the effects of an increase in the rate of inflation on the welfare of consumers. Welfare was reduced as a consequence for the hole country as well as wealth because of a reduction in savings.

When we allowed for heterogeneous consumers, we observed that this heterogeneity came about by assuming that these consumers received less than or more than proportional lump-sum transfers. In this case, those agents that received more than proportional real monetary transfers were benefited in terms of consumption and welfare but they were worst off in terms of wealth by an increase in the rate of inflation. On the other hand, agents that received less than proportional real monetary transfers experienced a reduction in their consumption and welfare levels as well as in their wealth levels. That is to say, agents that were being favored by a lump-sum transfers redistributive scheme became themselves

\footnotetext{
${ }^{9}$ As was the case in the original work by Calvo (1981) with constant rate of time preference.
} 
"winners" in every respect even though they held a relatively larger wealth (savings)

than those who received less than proportional real monetary transfers. 


\section{CHAPTER 4}

\section{COMMENTS ON THE ASSUMPTIONS USED IN CURRENCY SUBSTITUTION MODELS}

\subsection{INTRODUCTION}

This chapter will deal with some necessary, although probably not sufficient, conditions and assumptions on the models of currency substitution that follow. This exercise is needed because some results of the following chapters are directly linked to these assumptions.

This chapter has the intention of looking at these different assumptions and to explain their intuition. The literature on the issue of currency substitution is extensive, from the article written by Calvo and Rodriguez (1977) to the articles by Liviatan (1981), Calvo (1985), Engel (1989), Sturzenegger (1991, 1992, 1994), and Zou (1993).

At the same time we are also going to discuss the article by Obstfeld and Rogoff (1983) with the help of Weil $(1991)$ and Sturzenegger $(1991,1994)$ for the extension to a situation of two monies in the utility function. 


\subsection{THE CONTROVERSY}

This controversy arose after the publication by Calvo and Rodriguez (1977) of an article called 'A Model of Exchange Rate Determination under Currency Substitution and Rational Expectations'. In this model, which was not an optimizing model, ${ }^{1}$ the authors showed that "an increase in domestic money growth will cause an immediate depreciation of the currency." (Engel 1989, p. 47) Or conversely, that a decrease in the rate of growth of domestic money will lead to an appreciation of the currency. ${ }^{2}$ In fact, their analysis was due to concerns for what was happening in Argentina during those years.

Liviatan (1981) argued and showed in his article that "an increase in the rate of monetary expansion has the impact effect of creating a real appreciation of the exchange rate and a deterioration of the balance of payments, contrary to the results of Calvo and Rodríguez." (Liviatan 1987, p. 1218) He showed that this result

${ }^{1}$ Something noted by Liviatan (1981) in his response to Calvo and Rodriguez and then certified by Calvo (1985) and Engel (1989) in their respective responses to Liviatan (1981).

${ }^{2}$ The original article by Calvo and Rodriguez (1977) concluded that the exchange rate would vary depending in the monetary experiment, that is to say, the Purchasing Power Parity (PPP) will not hold. The optimizing models by Liviatan (1981), Calvo (1985), and Engel (1989) show an impact effect over the real exchange rate but were the long-run real exchange rate remained constant, i.e., the PPP holds. See Penati (1987) for a model with endogenous (and variable) rates of time preference where the PPP does not hold, just as in the original Calvo and Rodríguez (1977) article. 
came from considering both monetary balances, domestic and foreign, to behave like "cooperant" factors in utility. ${ }^{3}$ Had domestic money and foreign money behaved like "non-cooperant" factors in utility, then the cross partial derivatives between domestic and foreign monetary balances would be negative, and the Calvo and Rodriguez (1977) (henceforth C-R) results would stand.

Calvo's (1985, p.176) article argues further that "the 'cooperancy' assumption is not a sufficient condition to obtain the anti-C-R result." He says that "an implication of Liviatan's analysis must be that a slowing down of the rate of expansion of the money supply is associated with a large enough expansion of the long-run real wealth so as to call for an increase, not a decrease as in C-R, of the long-run stock of foreign money." "...We will argue that whether or not C-R results obtain crucially depends on the elasticity of substitution between consumption and liquidity services, $\sigma_{\mathrm{ul}}$ and between the two currencies in the 'production of liquidity', $\sigma_{\mathrm{mF}} . "($ Calvo 1985, p. 176) These issues will be extremely important later because our argument will be related to elasticity of substitution between currencies, although not with elasticity of substitution between consumption and liquidity services like in Calvo's 1985.

On his own, Engel (1989) tries to show that Liviatan's assumption is "mistaken." In his words "Liviatan (1981) provides a parallel model to Calvo and

3The "cooperancy" assumption, following Calvo (1985, p.187, note 4) is the same as being "Edgeworth-complementary" in utility, i.e., the cross partial derivative of the utility function with respect to the two monies is always positive. 
Rodríguez in which agents' behavior is optimal (rather than described by ad hoc equations). Liviatan concludes that an increase in domestic money growth leads to a real appreciation domestically, and thus the Calvo-Rodriguez result is not correct in a model in which agents optimize. This conclusion depends critically on an assumption about the nature of the utility of money function. It is argued here that Liviatan's justification of his assumption is mistaken." (Engel 1989, p. 47)

We think that these issues are important because several articles have use these conclusions and assumptions to justify their own conclusions and assumptions.

\section{3 "COOPERANCY VERSUS NON-COOPERANCY"}

To make our point here we are going to follow Engel's contention of "proof" of what Liviatan implied by saying "for a given $\pi, m$ and $f$ should be positively related" . . . "we see immediately that a positive relationship between $m$ and $f$ implies $v_{f m}>0 . "$ (Liviatan 1981, p.1226). So we are going to reproduce Engel's demonstration here (Engel 1989, pp.50-51): ${ }^{4}$

${ }^{4}$ See Engel (1989) for a much clear understanding of the equations or look at the appendix in which we have transcribed such equations. 
"A good guess about what Liviatan means by this statement is that, if in (3c) everything except for $m$ and $f$ are held constant (i.e., $c_{T}, c_{H}$, and $\pi+r$ ), then in order for the ratio $\frac{m}{f}$ to stay constant while $m$ and $f$ change, $v_{f m}$ must be positive. Mathematically, imposing that $\frac{m}{f}$ is constant, so that $d m=\left(\frac{m}{f}\right) d f$, and imposing that $d c_{T}, d c_{H}$, and $d(\pi+r)$ equal zero, from equation (4b) we must have (6b) $\left(v_{f m}+\left(\frac{m}{f}\right) v_{m m}\right) d f=0$. Since $v_{m m}$ is negative, Liviatan would conclude that $v_{f m}$ is positive.

The problem with this argument is that if equations (3) hold, and the nominal interest and consumption of the goods cannot change, then there is no way for demand for either money to change. It is not the terms in parentheses in (6b) that must be zero, but instead $d f$ itself must vanish. The simplest way to see this is to perform the same exercise on (4a) that was performed on (4b). We get $(6 \mathrm{c})\left(v_{f f}+\left(\frac{m}{f}\right) v_{f m}\right) d f=0$. For $(6 \mathrm{~b})$ and $(6 \mathrm{c})$ to hold simultaneously, $d f$ must be zero. So, in Liviatan's exercise, the $\frac{m}{f}$ ratio is kept constant because $m$ and $f$ themselves do not change. It says nothing about the correct sign for $v_{f m}$.

Liviatan claims to be looking for 'a portfolio allocation condition analogous to condition (6b) in the CR model.' It is argued above that this condition is achieved by allowing $v_{f m}$ to be negative, but perhaps the most compelling argument that Liviatan chose the wrong sign according to this guideline is that his conclusions are exactly the opposite of CR." 
Engel's argument is far from convincing and in fact from his explanation the only thing that we can conclude is that $v_{f m}$ can either be positive (cooperant, as Liviatan argues) or negative, as he himself argues. In Engel's "proof" there is nothing that could show that the sign of the cross partial derivative between domestic and foreign balances has any specific sign. The only thing that he shows, and probably without any doubt, is that is $d f$ that must be zero in these equations. So he cannot conclude, as he does, that the "most compelling argument that Liviatan chose the wrong sign according to this guideline is that his conclusion are exactly the opposite of CR." In fact, this is the reason why Liviatan's conclusions are the opposite of those found by CR. In one model monies are assumed to be cooperant in utility while in the other monies are assumed to be non-cooperant in utility. Then, the solution, as argued by Liviatan, will depend on whether one uses the assumption of cooperancy or of non-cooperancy of real monetary balances in utility.

\subsection{OUR ARGUMENT}

Our argument relates to both, the "cooperancy" assumption and the conclusion put forward by Calvo (1985) that elasticities of substitution play a big role in the determination of the changes in the exchange rate. We will also use the notion of the "essentiality" of real monetary balances put forward by Obstfeld and Rogoff 
(1983) and the extension of this condition to two currencies model made by Weil (1991) and Sturzenegger (1991, 1994).

Nevertheless, first, we want to use the words of caution put forward by Calvo in his 1985 article that reads (Calvo 1985, p. 185): "and, perhaps more interestingly, we have learned that in order to get closer to a more operational theory, we need a deeper understanding of the transactions technologies. Until that is available, I would advise extreme caution in the application of this, or any other theory involving currency substitution."

With these words of caution in mind we are then going to proceed with our demonstration.

Our argument starts with a discussion of the intuition behind the idea of the "essentiality" of money developed by Obstfeld and Rogoff (1983)(Henceforth, O-R). They showed that hyperinflations could be avoided by assuming that the government will "fractionally" back the currency, in a one currency model. In fact, they argued that, just the possibility of that backing by the government will be enough to avoid hyperinflations. ${ }^{5}$ Still, the essentiality of money could be imposed by legal institutional mechanisms. Let us say, if transacting with the government requires agents to use domestic balances, that could be considered an institutional backing of the currency.

${ }^{5}$ See Calvo (1994) for a recent argument on the U.S. Treasury backing of the Mexican peso. 
Giovannini and Turtelboom (1992, p. 20) argue that "when inflation reaches extremely high values, the economy naturally adopts substitutes to the depreciating currency. And, second, the inflating currency does not completely disappear. This stubbornest of the hyperinflating money is an unexplored phenomenon. It could be due both to legal enforcement of its use for some transactions (i.e., taxes to be paid in cash), and/or to the hysteresis-type of phenomena . . ."

The second argument here is that at any moment in time individuals could go and exchange their money balances for some positive amount of goods and/or services. From O-R (1983, p. 686) conclusions we read: "if the government fractionally backs the currency by guaranteeing a minimal real redemption value for money, the problem of speculative hyperinflation disappears. Even though the government need never exercise its redemption guarantee, hyperinflationary equilibria, in which the welfare of all is lower than in the steady-state equilibrium, are eliminated."

Still, they also argue that (O-R, p. 684) 'feasibility of the government's policy requires that the government have access to sufficient reserves of capital to purchase the entire money stock $M$ at the support price $\epsilon$. Otherwise, speculative inflationary paths involving a sudden run on the government's reserves cannot be excluded." 6

${ }^{6}$ This issue will be of utmost importance when discussing our conclusions about Argentina's recent policy of "backing" the peso on a one to one fixed parity with the dollar. However, Calvo (1994) makes a good point on Mexico's situation in 
The above argument is the relationship that links the currency substitution hypothesis with the real exchange rate determination. This is why the issues of cooperancy-non-cooperancy between currencies and elasticities of substitution between currencies come into play. The reason for this importance is the following. Since the supply of foreign currency depends fundamentally on whether there is a current account surplus or deficit, consumers know that if there is a run against the domestic currency (probably due to expectations of unsustainable nominal exchange rate policy, or due to ever increasing budget deficits financed through inflation tax, etc.) thus reducing foreign reserves to unsustainable levels, that governments, sooner rather than later, will have to abandon their nominal exchange rate policy and devaluate the exchange rate. The intuition behind this conclusion is that in order to restore reserves through a current account surplus, a nominal devaluation will produce a real exchange rate depreciation.

But instead of going into the issues of exchange rate determination, we are going to limit ourselves to the cases where PPP holds. ${ }^{7}$ However, before going into the model we still have to explain different issues that will not be covered in this

which he says that "M2 (not including cetes) was more than four times net international reserves; for Argentina, Chile, Colombia, and Uruguay, this ratio hovered around two or three. Finally, a more comprehensive measure of short-term government cum bank obligations like M3 (which includes cetes) was six times larger than net international reserves." (Calvo 1994, p.302)

${ }^{7}$ We are only simplifying our analysis to relate to the issues of this chapter, which are whether currencies are cooperant or non-cooperant factors in utility and how elasticities of substitution play a role in this analysis. 
chapter but that will be covered in other chapters. First, we are assuming that in a currency substitution model these currencies are not perfect substitutes between them. ${ }^{8}$ This case will be covered in following chapters. Second, since the supply of foreign currency depends on the current account, it is therefore obvious that if there is a surplus, the degree of substitutability between domestic and foreign balances will increase. However, this degree of substitutability will never be equal to $\infty$ (the perfect substitute case), while if there is a deficit, the degree of substitutability will decrease.

Then let us look at the parameterization made by Weil (1991):

$$
V\left(m_{1}, m_{2}\right)=\frac{\left(m_{1} m_{2}\right)^{(1-\alpha)}}{(1-\alpha)} \quad \alpha \geq 0, \alpha \neq 1
$$

and

$$
=\ln m_{1}+\ln m_{2} \quad \alpha=1
$$

He showed that this utility function, "which features a unit elasticity of substitution between the two currencies--includes both the case in which each currency is essential $(\alpha \geq 1)$ and the case in which each is inessential $(\alpha=0)$ since,

${ }^{8}$ Of course what we are implying is that these two currencies are a domestic one and a foreign one, one being supplied without cost by the government and another one which will be supplied only if there is a current account surplus. 
for instance,

$$
\lim _{m_{1} \rightarrow 0 ; m_{2}>0} m_{1} V_{1}=\lim _{m_{1} \rightarrow 0 ; m_{2}>0}\left(m_{1} m_{2}\right)^{(1-\alpha)}=0
$$

if and only if $\alpha<1$." (Weil 1991, p.298) Of course, if $\alpha \geq 1$ then it follows that these currencies are essential in utility.

We will see that Calvo's (1985) argument on Liviatan's (1981) conclusion is well founded. Weil shows that assuming that currencies are essential ( $\alpha=1$, although $\alpha>1$ will also give us cases where currencies are essential) reduces the scope for hyperinflationary paths.

But, what can we say about the cross partial derivatives of this function? What can we say about their sign? By taking derivatives of this function under the different assumptions we can show that if $\alpha=1$ then

$$
\frac{\partial V}{\partial m_{1}}=\frac{1}{m_{1}}
$$

and

$$
\frac{\partial^{2} V}{\partial m_{1} \partial m_{2}}=0
$$

similarly 


$$
\frac{\partial V}{\partial m_{2}}=\frac{1}{m_{2}}
$$

and

$$
\frac{\partial^{2} V}{\partial m_{2} \partial m_{1}}=0
$$

This means that domestic monetary balances are independent of foreign monetary balances. That is to say, domestic and foreign currency balances are not either cooperant or non-cooperant factors in utility. In this case hyperinflationary paths are ruled out because any other solution, other than the steady state solution, violate the transversality condition or the non negativity constraint on money balances. $^{9}$

What about the cases where monetary balances are essential but $\alpha>1$. Let us look at the case where $\alpha=2$. Then the partial derivatives and the cross partial between domestic and foreign currencies are

$$
\frac{\partial V}{\partial m_{1}}=\frac{1}{m_{1}^{2} m_{2}}>0
$$

and

${ }^{9}$ Or at least this is the case when using this parameterization. 


$$
\frac{\partial^{2} V}{\partial m_{1} \partial m_{2}}=-\frac{1}{\left(m_{1} m_{2}\right)^{2}}<0
$$

and similarly

$$
\frac{\partial V}{\partial m_{2}}=\frac{1}{m_{2}^{2} m_{1}}>0
$$

and

$$
\frac{\partial^{2} V}{\partial m_{2} \partial m_{1}}=-\frac{1}{\left(m_{2} m_{1}\right)^{2}}<0
$$

which means that as $\alpha$ increases to numbers strictly greater than 1 , these currencies are increasingly becoming substitutes, (or $\alpha>1, \ldots, \infty$, where infinity is the case for perfect substitution). That is to say, these currencies go from being independent $(\alpha=1)$ to being non-cooperant in utility.

But, what about the cases for which $0 \leq \alpha<1$ ? As we will show, these are the cases where the two currencies are cooperant (Edgeworth-complementary) in utility. This means that if the inflation rate of the domestic currency increases, then consumers will reduce their demand of both currencies, because (Zou 1993, p. 213) 
"the reduction of peso holdings following a higher peso inflation will reduce the marginal utility of the liquidity services from the dollar." Let us show this with the use of the same parameterization. Then if we assume that $\alpha=.5$ we have

$$
\frac{\partial V}{\partial m_{1}}=\frac{\sqrt{m_{2}}}{\sqrt{m_{1}}}>0
$$

and

$$
\frac{\partial^{2} V}{\partial m_{1} \partial m_{2}}=-\frac{1}{2 \sqrt{m_{1} m_{2}}}+\frac{1}{\sqrt{m_{1} m_{2}}}>0
$$

and similarly

$$
\frac{\partial V}{\partial m_{2}}=\frac{\sqrt{m_{1}}}{\sqrt{m_{2}}}>0
$$

and

$$
\frac{\partial^{2} V}{\partial m_{2} \partial m_{1}}=-\frac{1}{2 \sqrt{m_{1} m_{2}}}+\frac{1}{\sqrt{m_{1} m_{2}}}>0
$$

Then, the cross partial derivative being positive means that these two monies are 
cooperant in utility.

After looking at three different possibilities in terms of the relationship between the two monetary instruments, whether they are independent from each other, substitutes or complementary (cooperant) in utility, we could summarize the following results.

First, if monetary balances are essential $(\alpha \geq 1)$, these monetary balances could be independent from each other $(\alpha=1)$, or they could be substitutes, or noncooperant factors in utility $(\alpha>1)$.

Second, if monetary balances are inessential $(0 \leq \alpha<1)$ then these monetary balances are cooperant (Edgeworth-complementary) in utility.

However, we might ask, what does this has to do with the issue of whether the real exchange rate of a country appreciates or depreciates after an increase in the growth rate of money? Whether the real exchange rate appreciates or depreciates after an increase in the rate of growth of the domestic money supply depends, as Liviatan has argued, on whether the monies are cooperant or noncooperant in utility, or whether they are inessential or essential (with the exception of the case where these two monies are independent but essential.)

Of course, these results are dependent on the type of utility function we are using. A generalization of these results cannot be made at this moment because we might find that these results do not hold with a different utility function.

The above argument about monies being essential under these conditions 
is far different from a situation in which the government decides to "back" a new currency (as in Sturzenegger 1994). In our case, monies are essential by the decision of the individual consumer acting independently from the government. ${ }^{10}$ Therefore, our argument gives independence to the individual consumer to decide whether the marginal utility of liquidity services decreases (cooperant) when the growth rate of domestic money is increased or the marginal utility of liquidity services increases (non-cooperant) when there is an increase in the rate of growth of domestic currency.

The real issue here is that with currency substitution individual consumers are able to "endogenize" the changes in the money supply, which is almost always modeled to be exogenous to them. By this endogeneization, individuals are also endogenizing the effects of the fiscal deficit of the government, which has been argued to be one of the characteristics of high inflation, or hyperinflationary processes to occur.

\subsection{CONCLUSION}

The main conclusion to this chapter is that there is no "a-priori" presumption about the relationship between real monetary balances in models of currency substitution. Whether currencies are "cooperant," "non-cooperant," or "independent" in providing

${ }^{10}$ See Chapter 7 on this dissertation. 
utility to consumers is something that would have to be resolved within each different situation and model used.

Probably, the greatest concern about each of these assumptions would be its relationship with the stability and feasibility of solutions to changes in other variables and/or shocks to these systems. 


\section{APPENDIX TO CHAPTER 4}

This appendix has the sole and limited purpose of transcribing several necessary equations used in our arguments in Chapter 4 from an article by Charles Engel (1989, pp. 49-51). The equations being transcribed from that article have the same number as when they were published.

$$
u_{T}\left(c_{T}, c_{H}\right)=p u_{H}\left(c_{T}, c_{H}\right)
$$

$$
\frac{v_{f}}{u_{T}}=r+\pi^{*}-\frac{\dot{u}_{T}}{u_{T}}
$$

$$
\frac{v_{m}}{u_{T}}=r+\pi-\frac{\dot{u}_{T}}{u_{T}}
$$

$$
\dot{u}=0
$$

$$
v_{f f} d f+v_{f m} d m=\left(r+\pi^{*}\right) u_{T T} d c_{T}+\left(r+\pi^{*}\right) u_{T H} d c_{H}+u_{T} d\left(r+\pi^{*}\right)
$$

$$
v_{f m} d f+v_{m m} d m=(r+\pi) u_{T T} d c_{T}+(r+\pi) u_{T H} d c_{H}+u_{T} d(r+\pi)
$$

$$
\pi=g\left(\frac{m}{f}\right)
$$




\section{CHAPTER 5}

\section{RATIONAL HYPERINFLATION WITH CURRENCY SUBSTITUTION}

\subsection{INTRODUCTION}

In this chapter we are going to develop a model characterized by introducing two fiat currencies in the utility function. ${ }^{1}$ The main idea behind this exercise is to look at the effects of having two currencies over the optimal decision of the government.

But first we will be characterizing the Sidrauski (1967) model with money in the utility function to include the extension to hyperinflationary situations following Obstfeld and Rogoff (1983). In order to further simplify the analysis we are going to assume in this chapter that individuals face a constant, and fixed, rate of time preference.

${ }^{1}$ See Weil (1991) and Sturzenegger $(1991,1994)$ where they make an extension of Obstfeld and Rogoff (1983). 


\subsection{THE SIDRAUSKI MODEL AND HYPERINFLATIONS ${ }^{2}$}

The problem faced by consumers is the following:

$$
\operatorname{Max} V=\int_{0}^{\infty} u\left(c_{t}, m_{t}\right) e^{-\delta t} d t
$$

subject to

$$
\dot{m} \equiv y-c_{t}-\pi_{t} m_{t}+\tau_{t}
$$

where $c_{t}$ is individual consumption, $m_{t}$ is real monetary balances, $y$ is the individual income, $\pi_{t}$ is the rate of inflation, and $\tau_{t}$ is government lump-sum transfers. ${ }^{3}$ First order conditions for this problem are:

$$
\begin{gathered}
u_{c}(c, m)=\lambda \\
\frac{\dot{\lambda}}{\lambda}=\delta+\pi-\frac{u_{m}(c, m)}{\lambda} \\
\lim _{t \rightarrow \infty} \lambda e^{-\delta t} m_{t}=0
\end{gathered}
$$

${ }^{2}$ This analysis is similar to Blanchard and Fischer (1989) and Sturzenegger $(1991,1994)$. It is introduced here as an introduction to the two monies model.

${ }^{3}$ This model is similar to that used in Chapter 3 of this dissertation with the only difference that the rate of time preference is fixed, and constant. 
We are also have that ${ }^{4}$

$$
\frac{\dot{m}}{m}=\sigma-\pi
$$

and

$$
\tau=\sigma m
$$

where $\sigma$ is the rate of growth nominal money, which means that the government follows a constant money growth rule.

If we substitute equations (5.1.6) and (5.1.7) into (5.1.1) we get that at equilibrium, the level of consumption is $c_{t}=y$. Assuming that the utility function is separable in consumption and real money balances, and since $y$ is constant, the marginal utility of consumption is also constant, so $\dot{\lambda}=0$. After normalizing $c$ such that $\lambda=u_{c}=1$, then equation (5.1.4) becomes

$$
u_{m}(m)=\delta+\pi
$$

Then, substituting (4.1.6) into (4.1.8) we get

${ }^{4}$ Time subscripts have been dropped were no conflict arises. 


$$
\dot{m}=(\delta+\sigma) m-u_{m}(m) m
$$

which is a differential equation in $m$. This equation is unstable. The derivative of this equation with respect to $m$ near steady state is positive, $-u_{m m} m>0$. However, Obstfeld and Rogoff (1983) have shown that the steady state is not the only equilibrium. They showed that hyperdeflations can be ruled out because they violate the transversality condition, but the same will not be true for hyperinflations. We could have "rational" hyperinflations as long as

$$
\lim _{m \rightarrow 0} m u_{m}(m)=0
$$

even with a constant rate of money growth.

A different situation results if we assume that

$$
\lim _{m \rightarrow 0} m u_{m}(m)>0
$$

This condition implies that money has to be essential for rational hyperinflations to be ruled out, or that no amount of consumption can compensate consumers for the disutility of having zero real monetary balances. Graphically we have: 


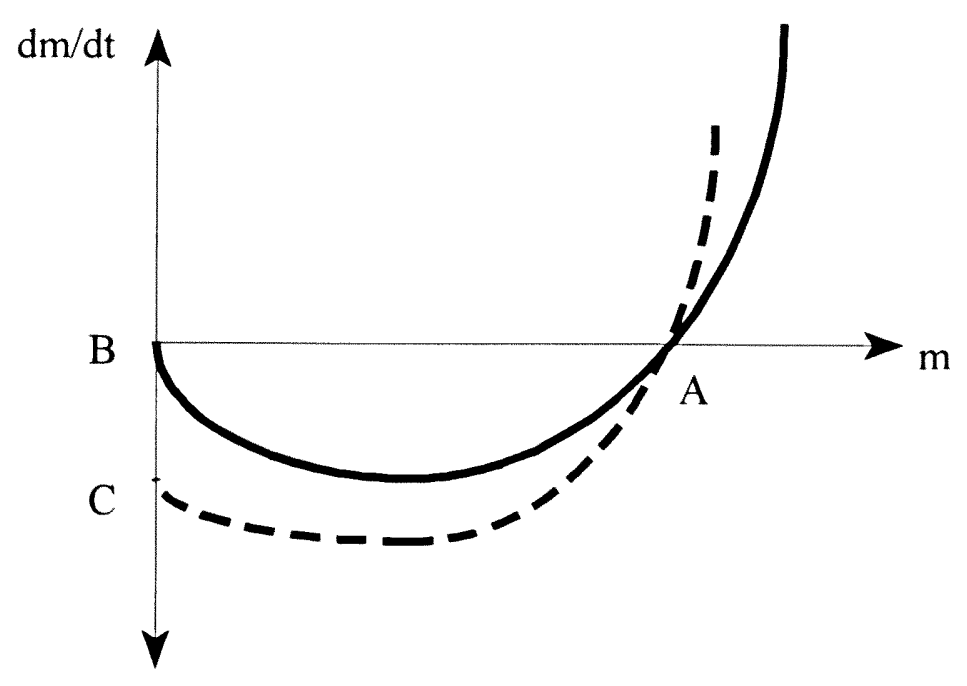

Figure 5.1 shows the cases where conditions (5.1.10) or (5.1.11) are assumed. The full line shows the case where money is "inessential" in utility (5.1.10) and the dashed line shows the case where money is "essential" (5.1.11). Real monetary balance being zero in the first case (at point B) represents the non-monetary equilibrium. In both cases' hyperdeflations (those points to the right of the steady state, point A) can be ruled out because they violate the transversality condition. However, while hyperdeflations can be ruled out, we can not rule out rational hyperinflations. Assumption (5.1.11) on the contrary, where money is essential in utility, do rules out hyperinflations by having a negative value for real monetary 
balances, something infeasible, at point $\mathrm{C}$ in figure 5.1.

\subsection{THE MODEL WITH TWO FIAT CURRENCIES}

What happens when the individual has the opportunity to substitute between currencies, or to use different currencies for making different kind of transactions. In Argentina, the use of domestic currency during periods of high inflation continued for small purchases and day to day small economic activities. However, big purchases, normally for durable goods, were, and are still being made (or at least quoted), using a different currency, especially US dollars. ${ }^{5}$

Many authors have argued that the existence of a substitute for a currency will tend to increase the inflation rate of the domestic currency. Therefore, governments should try to limit such type of behavior by consumers. However, there have been exceptions to the view that currency substitution is something that should be limited. To this respect we could mention Sturzenegger $(1991,1994)$ and Rostowski (1992), just to mention some of them. The first of them argues that in fact, with currency substitution, the rate of inflation of the original currency actually decreases when the new currency is introduced. The second one looks at the benefits of currency substitution in providing the correct signals to the economic

${ }^{5}$ Although there were sectors in society that were transacting in domestic currency even for the purchase of durable goods through the ASP. See Chapter 2 , Section 2.5.2, entitled Currency Substitution vs. Financial Adaptation. 
system. In his view, the economy can maintain or increase total output during inflationary situations by using a more stable currency, etc. While Rostowski's argument is interesting, we will not pursue it further. However, we are going to pursue Sturzenegger's (1994) argument.

Sturzenegger's (1994) argument goes basically on these lines: "Along the hyperinflationary path, people are willing to reduce monetary balances because they expect the inflation rate to increase in the future. If money is 'essential' in the sense that its marginal utility is very high, then the inflation rate required to induce people to substitute out of this currency must be very large. If money losses this 'essentiality' property -because a very close substitute develops or becomes available - then the inflation rate required to sustain a path with declining real monetary balances falls," (Sturzenegger 1994, p. 387) thus requiring a lower inflation rate on the original currency.

Let us look at the model with two currencies. The representative consumer solves the following problem:

$$
\operatorname{Max} V=\int_{0}^{\infty}\left[u(c)+v\left(m_{1}, m_{2}\right)\right] e^{-\rho t} d t
$$

subject to

$$
\dot{m}_{1}+\dot{m}_{2}=y-c-\pi_{1} m_{1}-\pi_{2} m_{2}+\tau_{1}+\tau_{2}
$$


where again $m_{1}$ and $m_{2}$ are real monetary balances in each currency, $\pi_{1}$ and $\pi_{2}$ are the rate of inflation corresponding to each currency, and $\tau_{1}$ and $\tau_{2}$ are lumpsum transfers in each currency.

Again, the first order conditions for this problem are

$$
\begin{gathered}
u_{c}(c)=\lambda \\
v_{m_{1}}\left(m_{1}, m_{2}\right)-\lambda \pi_{1}-\mu=0 \\
v_{m_{2}}\left(m_{1}, m_{2}\right)-\lambda \pi_{2}-\mu=0 \\
-\dot{\lambda}+\rho \lambda=\mu
\end{gathered}
$$

and

$$
\left(m_{1}+m_{2}\right) \lambda e^{-\rho t}=0
$$

and we also have the constant money supply rule in each currency:

$$
\frac{\dot{m}_{1}}{m_{1}}=\sigma_{1}-\pi_{1}
$$

and 


$$
\frac{\dot{m}_{2}}{m_{2}}=\sigma_{2}-\pi_{2}
$$

Proceeding with the corresponding substitutions, similar to those performed in section (5.1), but in this case for each currency, we get two differential equations in both real monetary balances:

$$
\begin{aligned}
& \dot{m}_{1}=\left[\sigma_{1}+\rho-v_{m_{1}}\left(m_{1}, m_{2}\right)\right] m_{1} \\
& \dot{m}_{2}=\left[\sigma_{2}+\rho-v_{m_{2}}\left(m_{1}, m_{2}\right)\right] m_{2}
\end{aligned}
$$

We are able to consider the system in two variables, $m_{1}$ and $m_{2}$, because we are assuming that this utility function is separable in consumption and real monetary balances. Furthermore, consumers are being lump-sum compensated in both currencies for the increased opportunity cost of holding real monetary balances in both currencies. ${ }^{6}$ That is to say, consumers do not have to give up consumption in order to acquire any one of these monetary balances. Then these two equations give us a system in both monies. As Sturzenegger (1994) argues, the system is completely unstable with two positive eigenvalues. The only equilibrium solution is at steady state. If condition (5.1.10) is assumed, there are multiple

${ }^{6}$ In Chapter 6 we deal with a situation in which consumers are only lump-sum compensated for the effects of domestic inflation but not for the effects in the foreign inflation rate. 
equilibria with the possibility of rational hyperinflationary paths converging to a single currency equilibria.

However, before continuing with the case discussed by Sturzenegger (1994) let us look at the case where these two monetary instruments are perfect substitutes. ${ }^{7}$ Philippe Weil (1991) considered this case and his results are shown in the following proposition:

"Proposition 1. If both (perfectly substitutable) currencies are valued, then the share in real world balances of the faster growing currency monotonically tends to $100 \%$ in the long run." ${ }^{8}$ (Weil 1991, p. 294)

Then, he concludes that "removing the obstacles to currency substitution while maintaining fixed parities must result in the eventual elimination of the slow growing currency." (Weil 1991, p. 295) This, he argues, is an example of the Gresham's Law of currency substitution in which "bad" money displaces "good" money from circulation.

His proof is based on the fact that there is perfect capital mobility and that

${ }^{7}$ This case was not considered by Sturzenegger (1994) although it would certainly apply to a situation in which the same government is the one introducing the new currency in this economy, i.e., the recent case of the Plan Real in Brazil is an example of this type of policy. However, if the issue is to "back" the currency, in the sense of applying condition (5.1.11) this could have been achieved just by backing the original currency without the need of introducing a new currency. See Chapter 5 in which we discus some issues concerning the backing of the currency by the government.

${ }^{8}$ For the proof to this proposition see Weil (1991, p. 295). 
the world interest rate is given. Then, the nominal interest rate must be equal across countries which, with an interest rate equal to the rate of time preference, implies that the inflation rate in both countries must be equal. The equality between inflation rates means that the demand for the faster growing currency must be increasing, and in the end going to $100 \%$ of real monetary balances. This is shown by point $M_{1}$ in Figure 5.2 .

His model is similar to that of Sturzenegger (1994) with the resulting two differential equations in two monetary balances. ${ }^{9}$ These two differential equations are as follows:

$$
\begin{aligned}
& \dot{m}_{1}=\left[\sigma_{1}+\rho\right] m_{1}-v^{\prime}\left(m_{1}+m_{2}\right) m_{1} \\
& \dot{m}_{2}=\left[\sigma_{2}+\rho\right] m_{2}-v^{\prime}\left(m_{1}+m_{2}\right) m_{2}
\end{aligned}
$$

If we assume that $\sigma_{1}>\sigma_{2}$, that is to say, that the rate of growth of $m_{1}$ is greater than the rate of growth of $m_{2}$, then we have the following figure:

${ }^{9}$ Although Weil (1991) is considering the case of two different countries, each one with their own currency, and perfect capital mobility between these countries. Furthermore, the level of consumption is not affected by this experiment. 


\section{Figure 5.2}

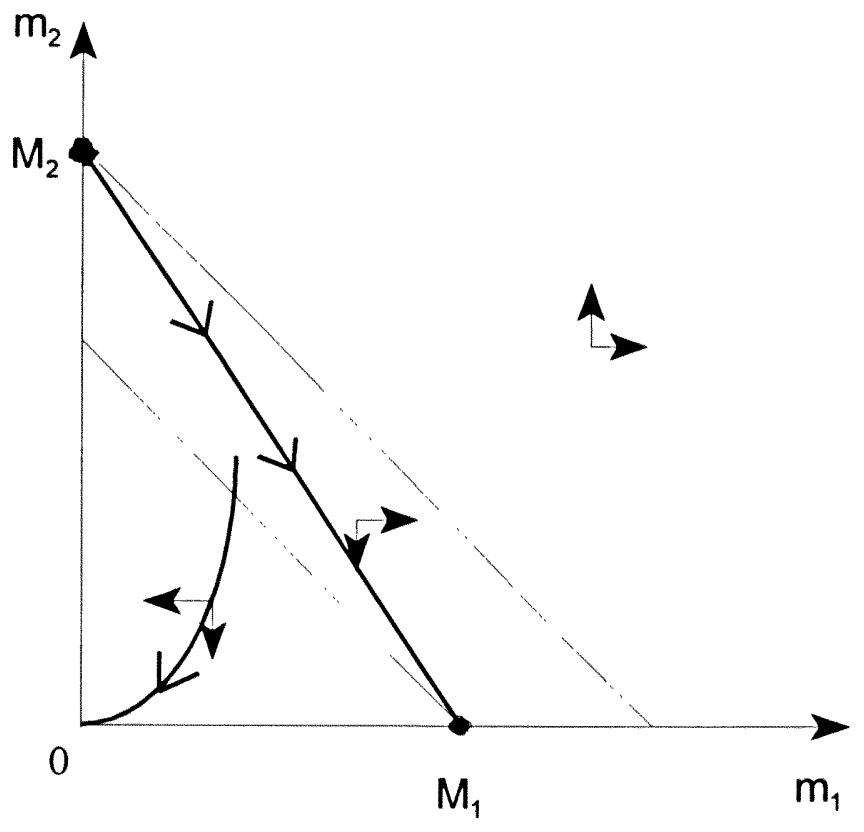

with the solutions to the system depending on whether we assume (5.1.10) or (5.1.11) on the monetary equilibrium. ${ }^{10}$

Then, summarizing Weil's conclusion we have that if $(5.1 .11)$ is assumed ${ }^{11}$ there are three possible outcomes. First, a steady state in which only $m_{1}$ is held,

${ }^{10}$ The case in which $\sigma_{2}>\sigma_{1}$ will give the same result in which the "bad" currency displaces the "good" currency.

${ }^{11}$ Remember from Chapter 4 that $(5.1 .11)$ implied that real monetary balances are "essential" in utility and assuming (5.1.10) implied that real monetary balances are "inessential" in utility. 
at point $M_{1}$ in Figure 5.2. Second, a steady state in which only $m_{2}$ is held, which is represented by point $M_{2}$, and third, a continuum of non-stationary equilibria which lies in the saddle-path connecting $M_{2}$ to $M_{1}$, in which the "good" currency is driven out from circulation. ${ }^{12}$ If, instead, $(5.1 .10)$ is assumed, then with the abovementioned solutions there is a fourth solution characterized by hyperinflationary paths in which both currencies disappear. This solution is shown in Figure 5.2 by the path ending at the origin and that passes below the path joining $M_{2}$ to $M_{1}$.

Then, if currencies are perfect substitutes, there will be situations in which there is the possibility of rational hyperinflationary solutions to develop. This point is extremely important ${ }^{13}$ because when currencies are no longer perfect substitutes then, rational hyperinflationary solutions may or may not be possible, depending on the assumptions we make. ${ }^{14}$

We are ready now to continue our discussion of Sturzenegger's (1994) argument with the important distinction that he is not considering a situation of perfectly substitutable currencies.

Using equations (5.2.10) and (5.2.11) we get the following Figure 5.3

${ }^{12}$ See Weil (1991) for a more complete view.

${ }^{13}$ This point is also stressed by Weil (1991).

${ }^{14} \mathrm{And}$ fundamentally, depending on the utility function used. We will see this latter on in the chapter. 


\section{Figure 5.3}

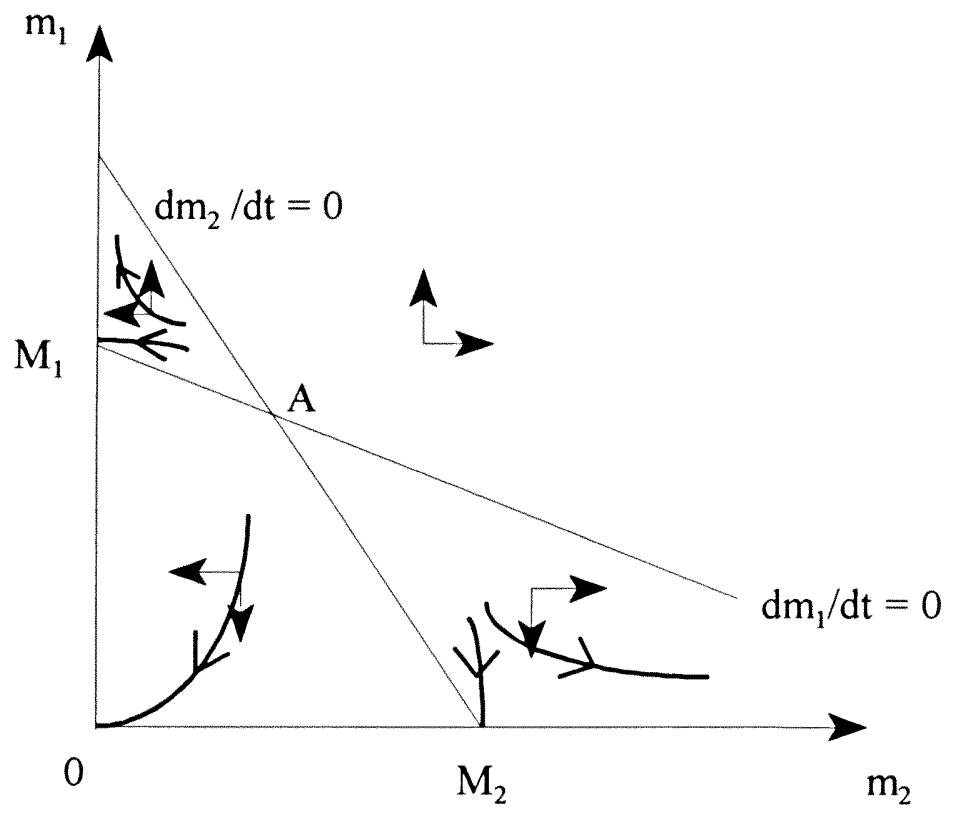

The steady state solution of this model is at point $A$. What about the possibility of hyperinflationary solutions? Sturzenergger (1994) argues that if we assume that $m_{1}$ is evolving through a hyperinflationary path, and another currency "backed" by the government is introduced, being this backed currency $m_{2}$, that the rate of inflation of the original currency decreases on the hyperinflationary path. Furthermore, he says to be working with a utility function characterized by a Baumol-Tobin-Barro transaction model.

He goes to great lengths to develop a utility function characterized by being 
separable in consumption and real monetary balances and by having negative cross partial derivatives for both monies. ${ }^{15}$ However, what he does not realize is that although he "imposes" that condition (5.1.11) applies to this utility function that is not so. Let us take from his utility function the partial derivative with respect to $m_{1} \cdot{ }^{16}$

For (5.1.11) to apply we require that the limit of

$$
\frac{\partial v}{\partial m_{1}}=\frac{2 k_{1}+2 k_{2} m_{2}^{2}}{\left(2 m_{1}+m_{2}\right)\left(2 m_{1}+m_{2}+k_{1}+k_{2} m_{2}^{2}\right)}
$$

times $m_{1}$ when $m_{1}$ goes to zero and $m_{2}$ goes to a constant to be different from zero. ${ }^{17}$ However, we see immediately that this limit is equal to zero, not different from zero. Thus this parametrization, although produces negative cross partial derivatives between the two monetary balances (thus monetary balances are "noncooperant" in utility), it does not fulfill condition (5.1.11) which is central to his argument.

Another point which is also central to his argument is the one that relates to

${ }^{15}$ See Chapter 4 for a discussion on the differences between the assumptions of "cooperancy" and "non-cooperancy" of real monetary balances.

${ }^{16}$ See Sturzenegger (1994) p. 382.

${ }^{17}$ Mathematically:

$$
\lim _{m_{1} \rightarrow 0, m_{2}=c} m_{1} v_{m_{1}}\left(m_{1}, m_{2}\right)>0
$$


the assumption that "while one currency is evolving through a hyperinflationary path, another currency "backed" by the government is introduced."(Sturzenegger 1994, p. 385) He argues that if the government introduces a new currency while the original currency is evolving through a hyperinflationary path, the inflation rate of the original currency must be lower because this money is losing its essentiality due to the introduction of the second currency. This argument seems to infer that the first money was "essential" in the first place which contradicts the argument that this essential money was suffering a hyperinflation. If $m_{1}$ was essential (i.e., condition [5.1.11] was assumed at the beginning for the original currency), then $m_{1}$ could not have been suffering a speculative hyperinflation in the first place. ${ }^{18}$

Blanchard and Fischer (1989, pp.244-45) argued this point in the following way: "Does the government have any way of avoiding hyperinflations? One institutional provision is "backing" of the currency. If the government provides a promise that one unit of currency can be exchanged at positive real value for goods (if goods are perishable, for a stream of goods), there cannot be hyperinflation. The reason is that under hyperinflation the price of money would eventually be low enough that individuals would exchange their money against goods with the government. From then on, the price of money could not decrease further. But if there cannot be hyperinflation from that time on, there cannot be hyperinflation

${ }^{18}$ See Chapter 7 for an extension to this argument. 
before that time either." 19

Then, point A on Figure 5.3 is the only steady state solution for this system. Any other solution will violate "either the transversality condition or the nonnegativity on prices," (Weil 1991, p. 298) if we assume that money is "essential" for utility, which is assuming (5.1.11) in the monetary equilibrium. However, if we assume (5.1.10), which is the condition that money is not essential in utility, then we could have rational hyperinflationary paths ending in a single currency or hyperinflationary paths without any currency, which is again the non-monetary equilibrium. These solutions are shown by the paths ending at $M_{1}, M_{2}$, and 0 (which is the origin), respectively, in Figure 5.3. We see here that using Sturzenegger's (1994) utility function, instead of Weil's, imperfect substitutability between currencies does not "reduce the scope for hyperinflationary equilibria" (Weil 1990, p. 300), as was argued by Weil. ${ }^{20}$

Weil's conclusion that imperfect substitutability reduces the scope for hyperinflationary equilibria is directly related to the parametrization used in his analysis.

Let us now increase the rate of growth of $m_{1}$ (an increase in $\left.\sigma_{1}\right)$. Then the

${ }^{19}$ There is another way in which the government can avoid hyperinflations, which is also considered by Blanchard and Fischer, which is called the "feedback rule." See Blanchard and Fischer (1989) for further details.

${ }^{20}$ See Weil (1990) and Chapter 4 of this dissertation. 
$\frac{d m_{1}}{d t}=0$ line will shift downwards, and since both monies are jump variables, ${ }^{21}$ the system will achieve its new equilibrium at higher holdings of $m_{2}$ and lower holdings of $m_{1}{ }^{22}$ or point B on Figure 5.4 .

\section{Figure 5.4}

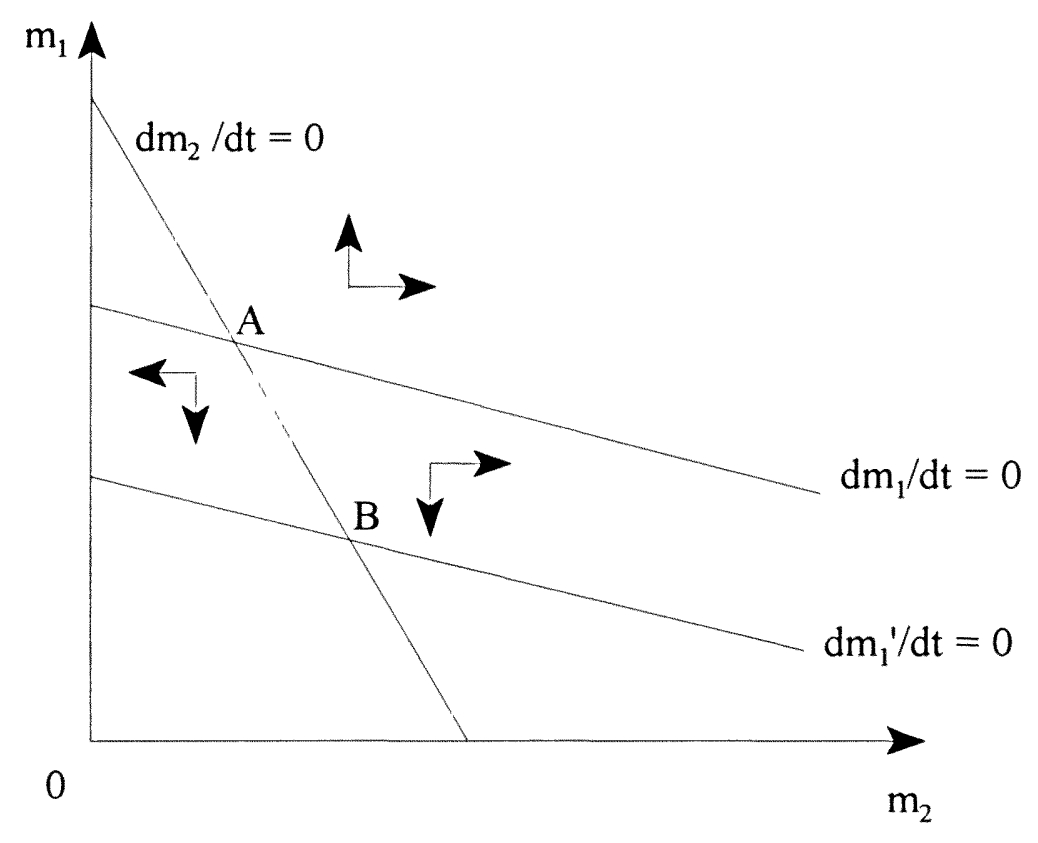

Sturzenegger calls this outcome, [that of an increase in the holdings of $m_{2}$ and a

${ }^{21}$ This point is important because if there are two monetary balances, one domestic and another one foreign, only the domestic money will be a jump variable, the foreign being determined by the surplus or deficits in the current account, or on the balance of payments if there is no capital mobility.

${ }^{22}$ We are assuming, for now, that the cross partial between both monetary balances is negative. 
reduction in the holdings of $m_{1}$ (from point A to point B in Figure 5.4) across steady state] the workings of a "Gresham's Law in reverse: across steady states, good money displaces bad." (Sturzenegger 1994, p. 385) However, the only thing that is happening here is that the opportunity cost of holding $m_{1}$ has increased (relative to that of holding $m_{2}$ ) and the rational individual chooses to hold a higher level of $m_{2}$ and a lower level of $m_{1}$. It has nothing to do with any type of Gresham Law. ${ }^{23}$

This will be shown later when we assume that real monetary balances are "cooperant" 24 in utility. If real monetary balances are "cooperant" in utility, then an increase in the rate of growth of $m_{1}$ will decrease holdings of both monies, not only those of $m_{1}$. Heng-Fu Zou has also stressed this point (1993).

Although the "cooperancy" assumption has been criticized in the literature, it still has some intuitive, albeit real, importance. The fact that full dollarization has never occurred in the Latin American countries experiencing currency substitution can be partially explained by assuming that monetary balances are "cooperant" in utility. Of course, institutional provisions may also be at the heart of this outcome. However, one of the most important arguments in favor of the "cooperancy" assumption could be the fact that there are some purchases (mostly small, day to

${ }^{23}$ If we look back at the case explained by Weil, the case when monies were perfect substitutes (Figure 5.2), then we can talk of a type of Gresham Law of currency substitution, as Weil himself does. This is the case where the "bad" money displaces the "good" money (i.e., going from $M_{2}$ to point $M_{1}$ in Figure 5.2).

${ }^{24}$ Recall from Chapter 4 that the "cooperancy" assumption implied positive cross partial derivatives between real monetary balances, instead of negative. 
day purchases) that are always conducted in the depreciating or (hyper)inflating currency (and that this hyperinflating currency does not disappear completely) whether big purchases are at least quoted (if not conducted) in some other secondary currency. ${ }^{25}$ Geographical issues and the lack of financial integration in less developed countries can give also some account of the limits to full dollarization. Financial adaptation is another reason that full dollarization has not occurred in Argentina. ${ }^{26}$

\subsection{CONCLUSION}

So far we have analyzed the cases where the same country creates a secondary currency, presumably with no capital mobility or with imperfect capital mobility. We have also looked at the case where there is perfect capital mobility (and presumably no risk in holding the high rate of growth currency), in which case if both monies are valued, there is the possibility of facing a type of Gresham Law of

${ }^{25}$ Sturzenegger (1992) argues that there are transaction costs that make the change to a "foreign" currency only profitable for high income individuals. But we can also argue that a $10 \%$ monthly inflation of a one dollar purchase will have different effects than a $10 \%$ monthly inflation over the purchase of a house or a car, or for that matter of any large purchase, in terms of money, or what is called the income elasticity of money. Furthermore, the difference need not be that between tradables and non-tradables, for which foreign money and domestic money are used, respectively, as several authors have argued.

${ }^{26}$ See Chapter 2 where we give several possible reasons for this outcome. See section 2.5.2 on Currency Substitution vs. Financial Adaptation. 
currency substitution in which the slow growing currency disappears from circulation.

Nevertheless, the important issue in this chapter relates to the characteristic of this second currency. If the currency is acquired through a current account surplus (or a balance of payments surplus, when capital is completely immobile) then, this second currency will not be a jump variable. That is to say, the currency cannot jump instantaneously to attain the new equilibrium. This is true when the country, or the individual consumers must sacrifice consumption to acquire these foreign monetary balances.

\section{Figure 5.5}

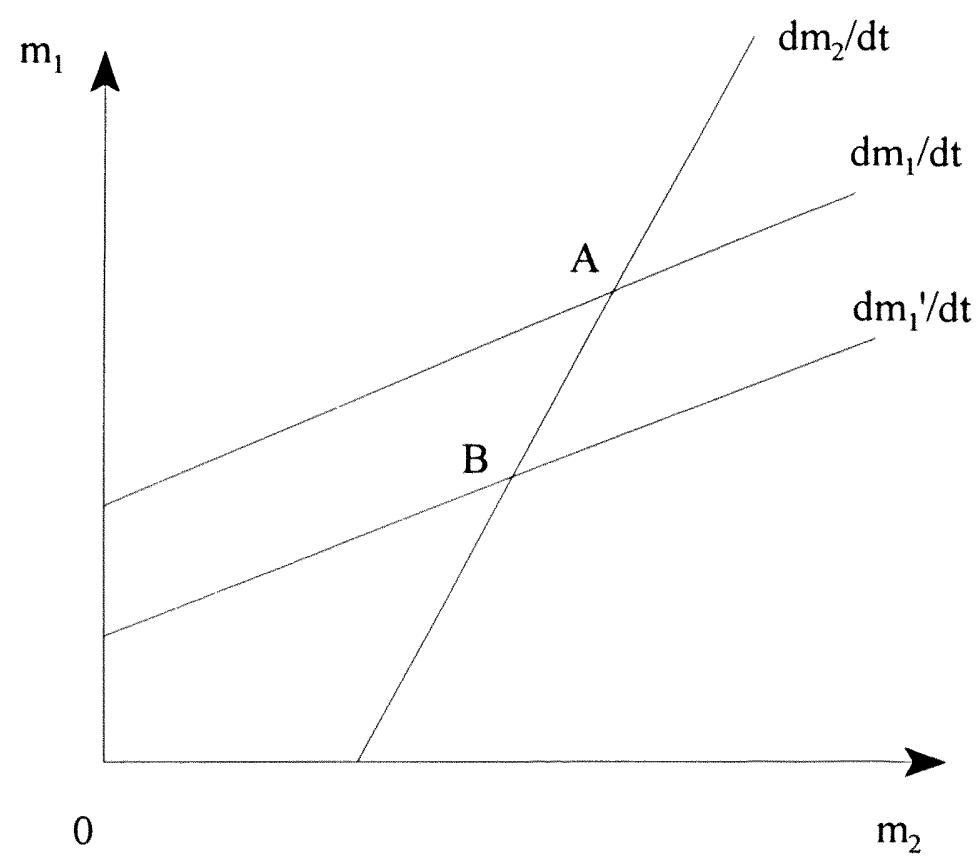


Figure 5.5 shows the case in which these two monetary balances are cooperant in utility. If there is an increase in the rate of growth of the domestic currency $\left(m_{1}\right)$ then the system jumps from point $A$ to point $B$ because in this case these two monetary balances are jump variables. 


\section{CHAPTER 6}

\section{DOLLARIZATION IN ARGENTINA: COOPERANT OR NON-COOPERANT MONETARY BALANCES?}

\subsection{INTRODUCTION}

In Chapter 5 we argued that with two currencies, the possibilities for instability to occur increases as the government increases the rate of growth of one of the currencies because agents could use the second currency. These models, or at least some of them, have also assumed that agentss are lump-sum compensated for the effects of the inflation tax. That is to say, agents are being compensated for the effects of the increased opportunity cost of holding real monetary balances. However, although we could easily assume that the representative agent is being lump-sum compensated by the domestic government for the opportunity cost of holding real domestic monetary balances, a different issue arises when one of the currencies is a foreign one and the domestic agent is not being compensated by the foreign government for holding this currency. In fact, this issue could be also put forward as another reason we may assume that these currencies are cooperant in utility, i.e., the cross partial derivative between the two monies is positive, and why 
full dollarization has not taken place in the presence of extreme levels of inflation (hyperinflation).

As Engel (1989) pointed it out, the reason for using the assumption of a zero foreign inflation rate in some models was due to the argument that the foreign inflation rate (that of the U.S. dollar) has been normally negligible in comparison to the rate of inflation of developing countries. Thus, the foreign inflation rate has been assumed to equal zero. Although this assumption is normally considered to be just a simplifying one, there have been some periods in recent U.S. history in which the inflation rate has been in the double digits. Although it may be negligible compared to the inflation taking place in Argentina for some recent high or hyperinflationary periods, holding foreign money balances becomes nevertheless relatively more costly as individuals increase their holdings of U.S. dollars, be it because of a higher domestic inflation rate or because increases in GDP per capita.

What is even much more interesting is the fact that there is a tradeoff between increasing the amount of real foreign monetary balances and consumption. That is to say, if the rate of growth of the domestic currency increases and domestic and foreign balances are non-cooperant in utility, consumption must be sacrificed in order to increase the holdings of foreign balances.

The above argument will help us in our conclusions that Argentina should not totally dollarize its economy because there is some level of foreign monetary holdings for which the individual agent would decrease the holdings of both, the 
domestic currency and the foreign one after an increase in the rate of growth of money supply, knowing that he is being lump-sum compensated for holding the domestic currency while he is not being compensated for holding the foreign one, and knowing, of course, that he has to continuously sacrifice consumption to increase its foreign real monetary balances.

A very low inflation rate in Argentina, with agents being lump-sum compensated for the inflation tax would presumably push agents to hold their monetary balances in domestic currency instead of foreign currency. However, this is not what is happening, and probably the reason has to be found in the lack of credibility in the continuity of the fixed parity between the peso and the dollar.

This lack of credibility could explain Argentina's "segmented" currency markets. In an interesting article, Aldo A. Arnaudo (Fundación Mediterránea Newsletter, August 1994) argues that this segmentation is shown by the existence of excess reserves in the dollar market while "the peso market has been in equilibrium in the sense that the demand for peso loans has been satisfied with available peso deposits." (Arnaudo 1994, p. 6) The Converibility Law conveys that if there are excess reserves in one currency, financial institutions could convert these excess reserves to the other currency in order to satisfy demand for that currency. However, expectations of possible devaluations and or the risk involved in these transactions has to be assumed by the same institutions. The difference in the interest rate paid for pesos and for dollars in the financial system gives some 
account of this segmentation.

This market segmentation for dollars and for pesos provides a good explanation for the "systematic gap between interest rates in the two markets, which is around $10 \%$ annually." (Arnaudo 1994, p. 7) He continues saying that: "The credibility of policies, or the reduction of economic uncertainty, is reflected in a number of indicators of behavior of economic agents locally and abroad. With regard to local agents these factors are reflected in their desire to hold deposits in dollars with lower remuneration and to borrow in pesos. With respect to foreign agents these considerations are reflected in the premiums charged to hold Argentine bonds listed in foreign stock exchanges and the classification of Argentina's country risk by international firms." (Arnaudo 1994, p. 7)

These are the characteristics of the development of the financial markets after the Convertibility Law of 1991. It basically shows that there has been an increase in the demand for domestic loans and an oversupply of dollars in the market, which is to say, the demand for dollar loans has decreased relative to the demand for peso loans.

This development shows that there is still a lack of credibility in the maintenance of the fixed exchange rate. That is to say, agents' expectations are that the government will not be able to maintain this parity. This means that individuals are suspicious of the government and are not willing to get into long term debt (or even short term debt) in dollars. Banks, on the other hand, will not 
extend their offerings of loans denominated in dollars because of expectations and of higher risk in the future. Or for that matter, banks are unwilling to convert their dollar deposits into pesos to be able to satisfy demand for loans in pesos as the Convertibility Law of 1991 stipulates.

\subsection{TRADE-OFF BETWEEN HOLDING FOREIGN MONETARY BALANCES AND CONSUMPTION}

It has normally been assumed that there are transaction costs of holding foreign monetary balances as compared to the costs of holding domestic monetary balances. Moreover, that there are transaction costs of changing from domestic to foreign monetary balances. But we have never concentrated on the costs in terms of forgone consumption that individuals in particular, and countries in general, must incur when deciding to hold an increased proportion of their monetary holdings in foreign balances. ${ }^{1}$ Higher income individuals will also pay a higher price, in terms of consumption, for holding higher foreign monetary balances as their income increases and as domestic and foreign inflation also increases.

This forgone consumption has two components: the first one is a transitory component, i.e., from one steady-state to the new steady state through a current account surplus (a surplus in the balance of payments if there is no capital

\footnotetext{
${ }^{1}$ Although the issue has been discussed before by Engel (1989), Zou (1993) and others.
} 
mobility $)^{2}$ in order to get the required foreign balances; the second will be given by an overall reduction in future consumption due to the effects of foreign inflation and an increased level of foreign monetary balances in the portfolio of individuals. ${ }^{3}$

We saw in Chapter 5 that substituting away from one money to the other entailed no change in consumption due to the increase holdings of the second currency. This was so because agents were lump-sum compensated for the increased opportunity cost of holding those balances. ${ }^{4}$ But fundamentally so because these two monetary balances were both jump variables (i.e., the system will move immediately to the new equilibrium without any other effect or change in consumption). However, this is not, in general, the behavior of these two variables (foreign and domestic monetary balances). In order for a country like Argentina to

${ }^{2}$ In Chapter 3 of this dissertation we had the case of an increase in the rate of inflation which produced a balance of payments deficit with no capital mobility. Agents were lump-sum compensated for the increased opportunity cost of inflation and when agents were holding only domestic monetary balances and the government was "indexing" the domestic currency to foreign reserves. However, Obstfeld (1981) showed that when there is perfect capital mobility and agents were allowed to hold foreign assets and at the same time government reserves were allowed to earn interest, which were later returned to the public in form of transfer payments, an increase in the rate of growth in the money supply will generate a current account surplus in order for the country to restore its reserves. See Obstfeld (1981) for further details.

${ }^{3}$ Although this is only true when we assume that monetary balances are noncooperant in utility.

${ }^{4}$ This was not the case in the model presented by Weil (1991) were consumers were not assumed to be lump-sum compensated for the increased opportunity cost of holding those monetary balances but where an increase in any of the monetary balances entailed no change in consumption now or in the future. 
increase its holdings of foreign currency the economy must generate a current account surplus (a balance of payments surplus if capital is immobile) in order to generate those desired foreign balances. Of course, this is true if these monetary balances are non-cooperant in utility. However, if monetary balances are cooperant in utility, an increase in the rate of growth of the domestic currency will produce a current account deficit and furthermore, it will increase the targeted long run level of consumption in the future.

Let us look at this issues using a model similar to those used in previous chapters but were foreign monetary balances are acquired through a current account surplus and consumers are not lump-sum compensated for the opportunity cost of holding real foreign monetary balances.

\subsection{TWO MONIES AGAIN: A FOREIGN AND A DOMESTIC ONE}

The issues discussed in the previous section are so far the best rationale for the assumption that these two monetary balances could be, at least for some levels of consumption (or for some level of income), cooperant in utility. Let us look, then, at a model characterized by having a domestic and a foreign money in the utility function in which agents are lump-sum compensated for the increase in the opportunity cost of holding domestic monetary balances but they are not 
compensated for holding the foreign monetary balances.

Then, consumers maximize the following function

$$
\operatorname{Max} V=\int_{0}^{\infty}[u(c)+v(m, f)] e^{-\rho t} d t
$$

subject to

$$
\dot{a}=y+\tau-c-\pi m-\pi_{f} f
$$

and

$$
a=f+m
$$

where $m$ is the domestically supplied currency and $f$ is the foreign currency. $\tau$ is again the government lump-sum transfers in domestic currency. $a$ is the stock of assets while $\dot{a}$ is the flow of assets for the individual agent. The nominal exchange rate is assumed to be fixed.

Again, the first order conditions for this problem are

$$
\begin{gathered}
u_{c}(c)=\lambda \\
v_{m}(m, f)-\lambda \pi-\mu=0 \\
v_{f}(m, f)-\lambda \pi_{f}-\mu=0
\end{gathered}
$$




$$
-\dot{\lambda}+\rho \lambda=\mu
$$

and

$$
\lim _{t \rightarrow \infty} a \lambda e^{-\rho t}=0
$$

and we also have the condition for the constant growth of the domestic money supply

$$
\frac{\dot{m}}{m}=\sigma-\pi
$$

while foreign balances will be acquired through a trade surplus.

Substituting (6.7) into (6.5) and (6.6) and assuming that we are at steady state (i.e., $\dot{m}=\dot{c}=\dot{f}=0$ ) and furthermore, since at steady state $\sigma=\pi$ from (6.9) we get the following equations

$$
\begin{aligned}
& v_{m}(m, f)-u^{\prime}(c)(\sigma+\rho)=0 \\
& v_{f}(m, f)-u^{\prime}(c)\left(\pi_{f}+\rho\right)=0
\end{aligned}
$$

and from the budget constraint we get a third equation

$$
y-c-\pi_{f} f=0
$$


Let us first totally differentiate the system (6.10)-(6.12) to do some comparative statics on the effects of an increase in the rate of growth of the domestic of money.

Then, totally differentiating (6.10)-(6.12) we get $^{5}$

$$
\left[\begin{array}{ccc}
-u^{\prime \prime}(c)(\sigma+\rho) & v_{m m} & v_{m f} \\
-u^{\prime \prime}(c)\left(\pi_{f}+\rho\right) & v_{f m} & v_{f f} \\
-1 & 0 & -\pi_{f}
\end{array}\right]\left[\begin{array}{l}
d c \\
d m \\
d f
\end{array}\right]=\left[\begin{array}{c}
u^{\prime}(c)(d \sigma+d \rho) \\
u^{\prime}(c)\left(d \pi_{f}+d \rho\right) \\
f d \pi_{f}-d y
\end{array}\right]
$$

The determinant of this matrix is

$$
\Delta=v_{m f}^{2}-v_{m m} v_{f f}+u^{\prime \prime}(c) \pi_{f}\left[(\sigma+\rho) v_{m f}-\left(\pi_{f}+\rho\right) v_{m m}\right]<0
$$

Using Cramer's rule we get the following results

$$
\begin{gathered}
\frac{d m}{d \sigma}=\frac{-u^{\prime}(c)}{\Delta}\left[v_{f f}+u^{\prime \prime}(c) \pi_{f}(\sigma+\rho)\right]<0 \\
\frac{d f}{d \sigma}=\frac{-u^{\prime}(c) v_{m f}}{\Delta}>0(<0) ; \quad \text { if } v_{m f}<0\left(v_{m f}>0\right) \\
\frac{d c}{d \sigma}=\frac{-u^{\prime}(c) \pi_{f} v_{m f}}{\Delta}<0(>0) ; \quad \text { if } v_{m f}<0\left(v_{m f}>0\right)
\end{gathered}
$$

${ }^{5}$ This is similar to Zou's (1993) analysis. 
These results show how important is the distinction between cooperancy and noncooperancy of monetary balances.

When domestic and foreign monetary balances are cooperant in utility, a higher rate of growth of the domestic money will reduce real domestic monetary balances while reducing holdings of foreign monetary balances. This implies, by looking at (6.17), that consumption will be higher at the new steady state because consumers will be holding fewer foreign monetary balances (remember that there is a trade-off between consumption and foreign monetary balances). At the same time they are lump-sum compensated due to the increase in the opportunity cost of holding domestic monetary balances.

On the other hand, if domestic and foreign monetary balances are noncooperant in utility, then, consumption will decrease and foreign monetary balances will increase in the new steady state.

But let us analyze the possible dynamics of this system. To do that, it is easier to reduce the number of dynamic equations to two. Then, we are going to use the following equations:

$$
\begin{gathered}
\dot{c}=\frac{-v_{m}(m, f)}{u^{\prime \prime}(c)}+\frac{u^{\prime}(c)}{u^{\prime \prime}(c)}(\sigma+\rho) \\
\dot{f}=y-c-\pi_{f} f
\end{gathered}
$$


Then we have:

$$
\left[\begin{array}{ll}
\frac{\partial \dot{c}}{\partial c} & \frac{\partial \dot{c}}{\partial f} \\
\frac{\partial \dot{f}}{\partial c} & \frac{\partial \dot{f}}{\partial f}
\end{array}\right]=\left[\begin{array}{cc}
(\sigma+\rho) & \frac{-v_{m f}}{u^{\prime \prime}(c)} \\
-1 & -\pi_{f}
\end{array}\right]
$$

The determinant is:

$$
\text { determinant }=-\pi_{f}(\sigma+\rho)-\frac{v_{m f}}{u^{\prime \prime}(c)}<0
$$

In this case it does not matter whether the monies are cooperant or non-cooperant, the determinant will always be negative.

The trace is:

$$
\text { trace }=(\sigma+\rho)-\pi_{f}>0
$$

which can almost always be assumed to be positive.

However, the system will be characterized by two possibilities, and in this 
case these possibilities will depend on the sign of the cross partial derivative between the two monetary balances, i.e., whether they are cooperant or noncooperant in utility.

Let us look at the slope of the $\dot{c}=0$ and $\dot{f}=0$ curves. Then, the slope of these two curves is given by

$$
\begin{aligned}
& \text { slope of } \dot{c}=0 ;-\frac{\frac{\partial \dot{c}}{\partial \dot{f}}}{\frac{\partial \dot{c}}{\partial c}}=\frac{v_{m f}}{u^{\prime \prime}(c)(\sigma+\rho)}>0(<0) ; \text { if } v_{m f}<0(>0) \\
& \text { slope of } \dot{f}=0 ;-\frac{\frac{\partial \dot{f}}{\partial f}}{\frac{\partial \dot{f}}{\partial c}}=-\pi_{f}<0
\end{aligned}
$$

Then, if $v_{m f}<0$, we have: 


\section{Figure 6.1}

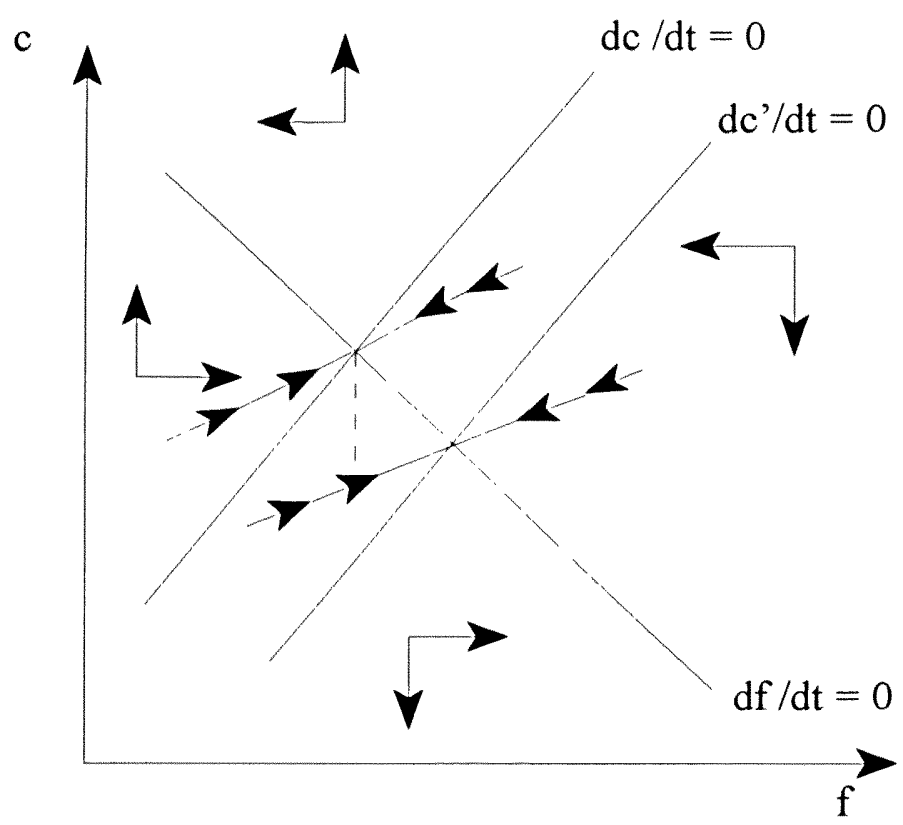

Figure 6.1 shows how an increase in the rate of growth of domestic money shifts the $\dot{c}=0$ to the right and creates a trade surplus (current account surplus or balance of payments surplus if capital is not mobile) in order for the country to get the necessary higher foreign balances. That is to say, in order for a surplus to take place we need the exchange rate to depreciate.

It is also shown that consumption overshoots its new long run level. So, if currencies are non-cooperant in utility, consumption is not only lower in the new steady state but it is even lower in the transition from the original steady state to the new steady state. 
If these monetary balances are cooperant in utility, the dynamics are different. Let us see how will the system behave if we assume that $v_{m f}>0$. Figure 6.2 gives us the picture:

\section{Figure 6.2}

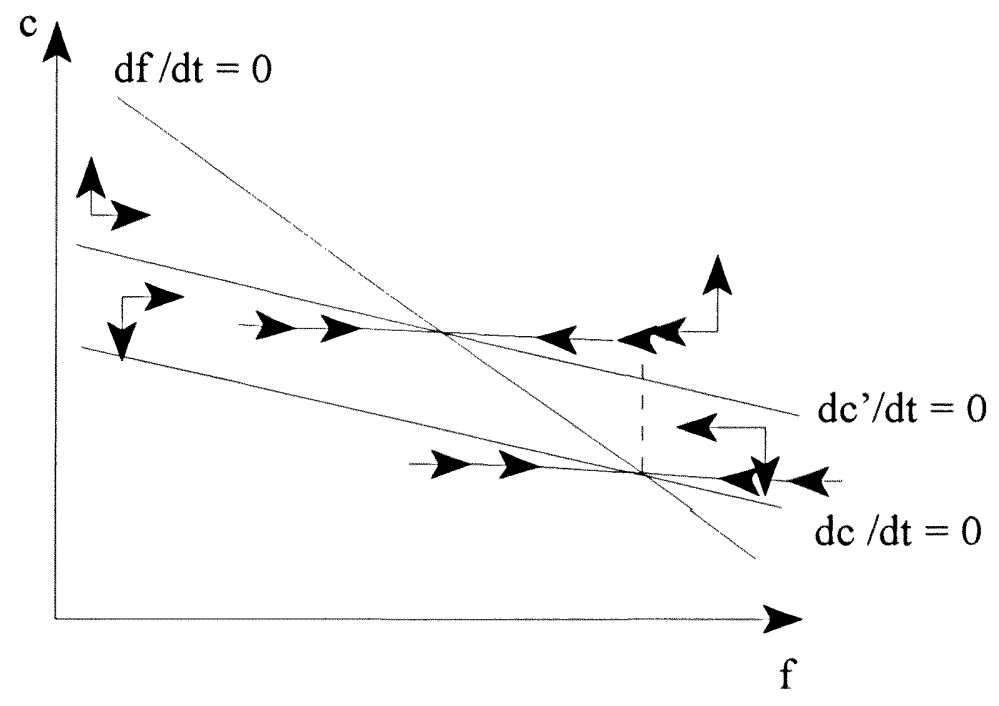

Figure 6.2 shows the case where currencies are cooperant in utility. An increase in the rate of growth of the domestic money shifts the $\dot{c}=0$ upwards to $\dot{c}^{\prime}=0$. Since the system shows saddle path stability, just as before, we have the following.

Agents will want to get rid of the excess foreign monetary balances and the only way (other than throw them away) for them to do this is through a current 
account deficit, by which individuals increase their consumption levels in exchange for foreign monetary balances.

But what happens if there is a decrease in the rate of growth of the domestic money? If monetary balances are cooperant in utility, the system will create a current account surplus in order for agents to get accumulate foreign monetary balances. At the same time, domestic monetary balances will also increase during the transition. Consumption will decrease in the new steady state due to the tradeoff between holding foreign monetary balances and consumption.

If monetary balances are non-cooperant in utility and there is a decrease in the rate of growth in the domestic money supply there will be a current account deficit while consumers decrease their foreign monetary holdings and increase their domestic monetary holdings.

However, this is not the only possibility. the above mentioned example is only true if foreign inflation is very high. If foreign inflation is very low, the system behaves in a different fashion.

This case is characterized by a spiral type of behavior in which the country will expreience a succession of current account deficits followed by current account surpluses, and so forth, until the system reaches the new equilibrium steady state. This type of dynamics is called a "stable focus." Figure 6.3 shows the dynamics of this system. 


\section{Figure 6.3}

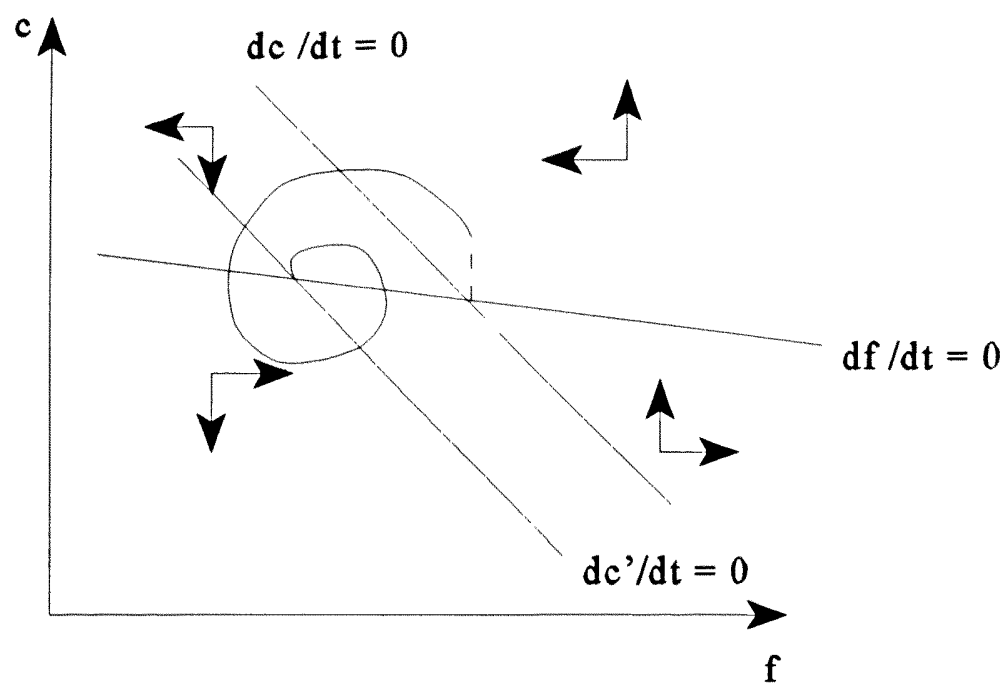

This figure exemplifies the case when monetary balances are cooperant in utility and when the foreign inflation rate is low.

\subsection{Conclusion}

The title of this chapter is Dollarization in Argentina: Cooperant or Non-Cooperant Monetary Balances?, and not Currency Substitution in Argentina. The reason for this is that the process analyzed in this chapter is the process of accumulation or decumulation of foreign monetary balances, not of currency substitution, which is the last stage in the process of dollarization (Calvo and Végh, 1992). 
In order for currency substitution to exist, a country must have had a process of accumulation of foreign monetary balances (in our case of dollarization) that enable agents at some point in time to determine whether they are going to use foreign monetary balances to conduct economic transactions. Then, at least in the case of Argentina, the issue of cooperancy-non-cooperancy has to be analyzed in this context and not on the context of currency substitution. That is to say, whether agents increase or decrease their holdings of foreign monetary balances as a store of value is largely independent from the decision of using those balances for transaction processes. Of course, currency substitution is not possible if it has not been preceeded by a process of dollarization through the years. However, whether agents use those balances for transaction purposes depends on different variables like institutional provisions, legal requirements, existence of capital markets, financial integration of the country (i.e., homogeneous access to foreign monetary balances), etc. 


\section{CHAPTER 7}

\section{CURRENCY SUBSTITUTION IN ARGENTINA: INTRODUCING AN INDEXED CURRENCY OR ENDOGENOUS MONEY SUPPLY?}

So far we have analyzed in Chapter 6 how is it that Argentines have been hoarding or accumulating foreign monetary balances through the years. We have also seen how the distinction between cooperant or non-cooperant monetary balances affected this decumulation-accumulation process. However, in this chapter we are going to look at the same distinction (cooperant vs. non-cooperant) but in a very different setting. The model introduced here has the characteristic of allowing agents to decide, independently from the government, whether to increase or decrease real monetary balances in both currencies. But before doing that we have to distinguish between two different types of hyperinflationary processes.

\subsection{Two Strands of Hyperinflation}

It is hardly unlikely that Argentina's hyperinflationary experiences have been a consequence of "speculative" processes (i.e., "rational hyperinflations"), or what has been called a "bubble in the price level." However, Sturzenegger (1994) argues that two such bubbles have been found for the periods 89:3-89:7 and 89:11-90:3. 
This type of hyperinflation assumes that the rate of growth of the money supply is constant, something uncharacteristic of the money supply growth pattern in Argentina for the last 40 to 50 years.

This "rational hyperinflation" has the characteristic also that the hyperinflating currency, in our case the domestic currency, if it is not essential in utility, disappears from circulation. Since this outcome has not occurred in Argentina, a different explanation may be at the heart of this hyperinflationary process. In fact, the way in which foreign monetary balances are accumulateddecumulated may prevent this economy to totally dollarize.

The second type or strand of hyperinflation is the one that occurs when there is a continuous growth in the money supply, in which case the rate of inflation closely follows the growth rate of the money supply. In this case, the domestic money need not disappear from circulation, even in the presence of a hyperinflationary process. This process, we argue, closely resembles the hyperinflationary processes characteristic of the Argentine pattern.

The following charts tries to look at the relationship between the growth rate of inflation and the rate of growth of money supply for two different periods. 


\section{CPI and Nominal Money Supply}

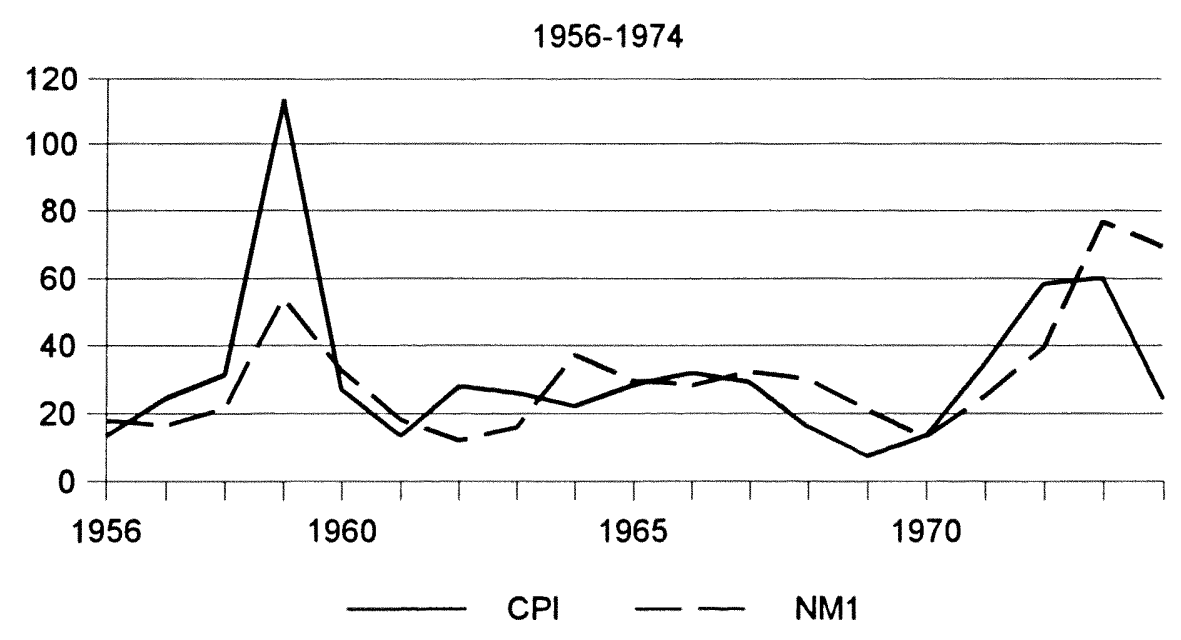

\section{CPI and Nominal Money Supply}

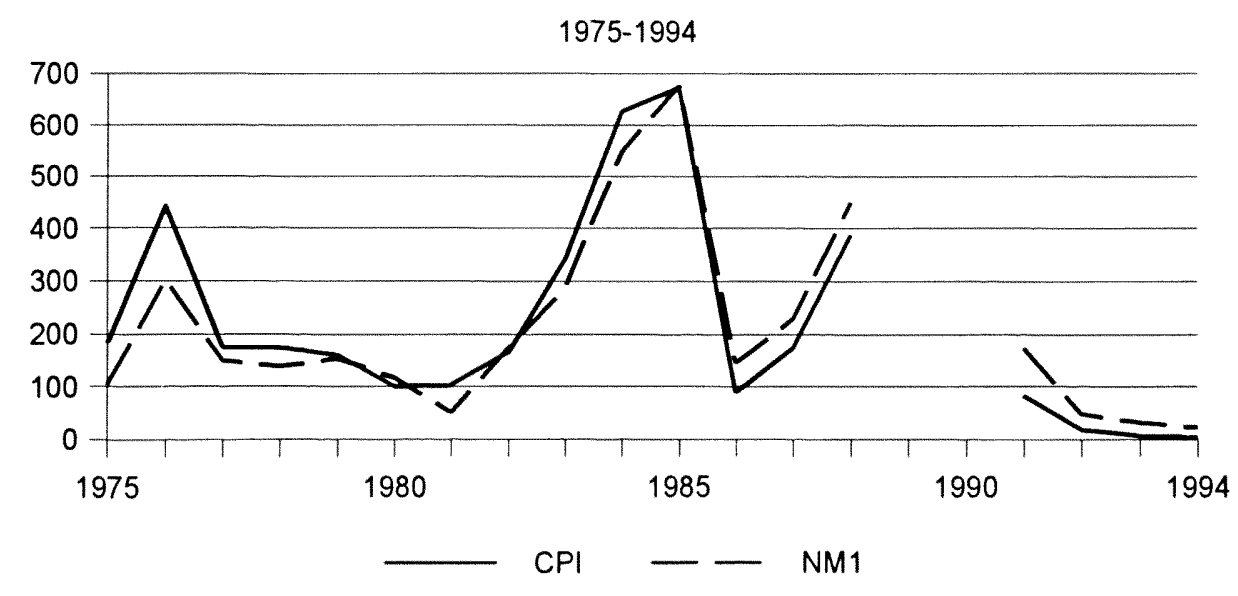

These charts are only introduced in order to convey that before 1974 the relationship between the rate of inflation and the rate of growth of the nominal money supply was extremely different from that found after 1975 . We have 
excluded the rate of inflation and the rate of nominal money growth for 1989 and 1990 on purpose because its inclusion will distort the relationship between these two variables. In order to look at our argument we proceeded to perform some regressions.

Three regressions were performed in order to look at this trend. The first two regressions comprises the period from 1956 to 1974 . The second period goes from 1975 to 1994 . This division was made due to the fact that the behavior between the growth rate of the money supply and the growth rate of inflation presents a striking difference between these two periods.

The dependent variable will be the rate of inflation (CPI) and the independent variable is the rate of growth of the nominal money supply (NM1). These are simple regressions, just to show the relationship between these two variables during these two periods. The results are the following:

The first regression is for the period 1956-1974: CPI regressed on NM1.

\begin{tabular}{|c|c|c|c|c|}
\hline Warioso & 6ooflogris. & sion wings: & Sitivitic & wrang yig \\
\hline Constant & 8.492364 & 9.5220802 & 0.9188367 & 0.3710 \\
\hline NM1 & 0.7417828 & 0.2661415 & 2.7871741 & 0.0126 \\
\hline R-Squared & 0.313640 & \multicolumn{2}{|c|}{ Mean of Dependent Var. } & 31.84211 \\
\hline Adj. R-Sq. & 0.273266 & \multicolumn{2}{|c|}{ S.D. of Dependent Var. } & 23.99484 \\
\hline S.E. of Reg. & 20.45529 & \multicolumn{2}{|c|}{ Sum of Squared Resid. } & 7113.124 \\
\hline Log Likelih. & -83.24978 & \multicolumn{2}{|l|}{ F-Statistic } & 7.768339 \\
\hline D.W. Stat. & 1.645586 & \multicolumn{2}{|c|}{ Prob(F-Statistic) } & 0.12642 \\
\hline
\end{tabular}


Since the Adjusted R-Squared was extremely low we decided to include a lag in the growth of the money supply. The results were the following:

\begin{tabular}{|c|c|c|c|c|}
\hline Yormolo: & 8004100110 & 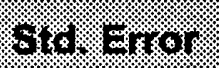 & torinistic & (2) \\
\hline Constant & 21.978772 & 9.1622352 & 2.3988439 & 0.0299 \\
\hline NM1 & 1.2265432 & 0.2811786 & 4.3621505 & 0.0006 \\
\hline $\operatorname{NM1}(-1)$ & -0.9719219 & 0.3221549 & -3.0169397 & 0.0087 \\
\hline R-Squared & 0.562640 & \multicolumn{2}{|c|}{ Mean of Dependent Var. } & 32.86667 \\
\hline Adj. R-Sq. & 0.504326 & \multicolumn{2}{|c|}{ S.D. of Dependent Var. } & 24.25907 \\
\hline S.E. of Reg. & 17.07939 & \multicolumn{2}{|c|}{ Sum of Squared Resid. } & 4375.583 \\
\hline Log Likelih. & -74.98170 & \multicolumn{2}{|l|}{ F-Statistic } & 9.648356 \\
\hline D.W. Stat. & 1.6620894 & \multicolumn{2}{|c|}{ Prob(F-Statistic) } & 0.002024 \\
\hline
\end{tabular}

Next we proceeded to perform the same regression for the period 1975-1994 and the results were completely different. The Adjusted R-Squared increased to .99 for this period, compared to an Adjusted R-Squared of .27 and .50 for the period 1956-1974. The complete results were the following: 


\begin{tabular}{|c|c|c|c|c|}
\hline Yoritbie & Coonticient: & Sto. Ingror & tistativitic & 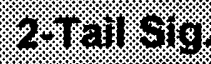 \\
\hline Constant & 12.796620 & 24.443932 & 0.5235091 & 0.6070 \\
\hline NM1 & 1.0381425 & 0.0217825 & 47.659399 & 0.0000 \\
\hline R-Squared & 0.992138 & \multicolumn{2}{|c|}{ Mean of Dependent Var. } & 509.2000 \\
\hline Adj. R-Sq. & 0.991701 & \multicolumn{2}{|c|}{ S.D. of Dependent Var. } & 1085.586 \\
\hline S.E. of Reg. & 98.89592 & \multicolumn{2}{|c|}{ Sum of Squared Resid. } & 176047.3 \\
\hline Log Likelih. & -119.2065 & \multicolumn{2}{|l|}{ F-Statistic } & 2271.418 \\
\hline D.W. Stat. & 2.207641 & \multicolumn{2}{|c|}{ Prob(F-Statistic) } & 0.000000 \\
\hline
\end{tabular}

\subsection{Rational Hyperinflation: Introducing An Indexed Currency}

Sturzenegger (1994) has shown that the introduction of an indexed currency while the original currency is experiencing a hyperinflation reduces the rate of inflation in the new equilibrium. However, there are some problems with this analysis. We are now going to analyze this problems in further detail. ${ }^{1}$

We are going to use equations (5.2.10) and (5.2.11) for this analysis. We introduce them here to proceed with our analysis. Then we have two equations given by: ${ }^{2}$

${ }^{1}$ In Chapter 4 we gave an introduction to this issue.

${ }^{2}$ See Sturzenegger (1994) for further details. 


$$
\begin{aligned}
& \dot{m}_{1}=\left[\sigma_{1}+\rho-v_{m_{1}}\left(m_{1}, m_{2}\right)\right] m_{1} \\
& \dot{m}_{2}=\left[\sigma_{2}+\rho-v_{m_{2}}\left(m_{1}, m_{2}\right)\right] m_{2}
\end{aligned}
$$

These equations give us a dynamic system in two variables, $m_{1}$ and $m_{2}$. The system is completely unstable with the only solution to it being at steady state. Graphically we have:

\section{Figure 7.1}

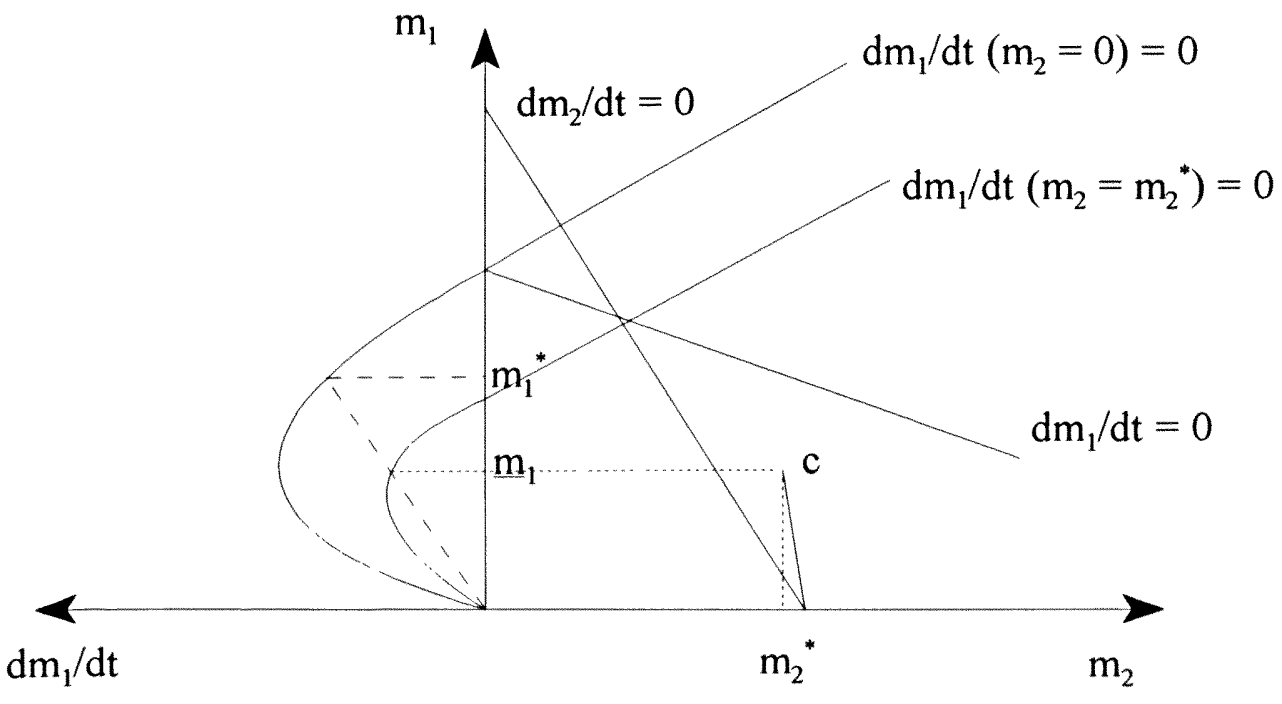


Sturzenegger (1994) argues that if we assume that the government introduces an indexed currency, $m_{2}$, while the original currency, $m_{1}$, is evolving through a hyperinflationary path, that the rate of inflation required to reduce monetary balances of the original currency is reduced, thus reducing the rate of inflation for the original currency.

He argues that this is shown by looking at the slope of the $\frac{\dot{m}_{1}}{m_{1}}$ curve, that is to say, "the slope of the line that starting at the origin goes through a particular point in the $\dot{m}_{1}=0$ curve." (Sturzenegger 1994, p. 386) This slope increases if real monetary balances are above $m_{1}{ }^{*}$ and decreases in absolute value if real monetary balances are below $m_{1}^{*}$. Thus the inflation rate decreases as the economy moves to its new equilibrium at point $c$. However, there are two problems here. The first one is that, although his analysis is correct, nothing prevents these monetary balances for $m_{1}$ to continue in its hyperinflationary path since point $c$ is not a steady state solution. That is to say, after the initial reduction in the rate of inflation, $m_{1}$ can continue to suffer a hyperinflation, which means that after an initial drop in the inflation rate, from the initial situation to point $c$, the economy will suffer a new hyperinflation for which the rate of inflation will continuously increase as monetary balances for the original currency go to zero. This could also be an explanation to what happened in Argentina between these two periods (89:3-89:7 and 89:11-90:3). Of course, this will be only true if we agree that the Argentine government introduced an indexed currency between the first and the second episode of 
hyperinflation, which is not the case for Argentina.

The second problem with this analysis is the notion that "speculative" hyperinflations can arise when we have an "essential" currency. If $m_{1}$ was essential, then, speculative or rational hyperinflations could not arise in the first place. This tends to confirm our position that Argentina's hyperinflation was of the second kind or strand, it was not a speculative hyperinflation in the first place.

We showed in Chapter 5 that even a Baumol-Tobin-Barro quadratic utility function in real monetary balances used by Sturzenegger (1994) did not allow us to impose condition (5.1.11) to the monetary equilibrium. However, we should not discount the possibility of finding a different utility function that will allow us to have the same nice characteristics assumed by Sturzenegger (1994). Furthermore, Argentina's situation is not that of a government introducing an indexed currency to reduce the rate of inflation of the original currency. In Argentina, individual agents have been hoarding, or accumulating foreign real monetary balances to minimize the effects of a government that has been financing the deficit through money creation. This issue further allow us to believe that domestic monetary balances continue to be essential, at least legally, in the presence of high inflation, or even hyperinflation. 


\subsection{The Case Of Argentina: Essential Monetary Balances}

As we argued before, Argentineans have been accumulating foreign monetary balances through the years. Furthermore, starting approximately in the 1970 s the country experienced a phenomenon called currency substitution by which some purchases were being performed, or at least quoted using the U.S. dollar instead of the domestic currency. At the beginning, durable goods transactions, such as the purchase of real estate and other durable goods, were performed or at least quoted using foreign currency. As time went by and as the rate of inflation increased, a higher number of transactions became a part of this dollar market.

In Argentina's case, individual agents started to use the foreign currency as a medium of exchange, not only as a unit of account or as a store of value as described in previous chapters. The Argentine government did not choose to introduce this alternative currency so as to decrease the rate of inflation of the original, domestic currency.

\subsubsection{The Model With Essential Monetary Balances}

In order to make our point, which will try to introduce the workings of the Convertibility Law of 1991, we are going to specialize our utility function. But first, we are going to set up the general model and make the assumptions that 
characterizes this Law.

Individual agents once again solve the following maximizing problem:

$$
\operatorname{Max} V=\int_{0}^{\infty}[u(c, f)+v(m)] e^{-\rho t} d t
$$

subject to

$$
\dot{a}=\dot{m}+\dot{f}=y-c-\pi m-\pi_{f} f+\tau
$$

and

$$
a=m+f
$$

First order conditions for this maximization problem are given by:

$$
u_{c}(c, f)=\lambda
$$

$$
\begin{gathered}
v^{\prime}(m)-\lambda \pi-\mu=0 \\
u_{f}(c, f)-\lambda \pi_{f}-\mu=0 \\
-\dot{\lambda}+\rho \lambda=\mu
\end{gathered}
$$

and 


$$
\lim _{t \rightarrow \infty} a \lambda e^{-\rho t}=0
$$

and we also have the condition for the constant growth of the domestic money supply

$$
\frac{\dot{m}}{m}=\sigma-\pi
$$

The implication here is that after the Convertibility Law, the Argentine Government lost its control over the money supply due to the fact that domestic money supply depends on the level of reserves on a one-to-one basis with the dollar.

The parametrization used here is the following:

$$
\operatorname{Max} \int_{0}^{\infty}\left[\frac{(c f)^{1-\alpha}}{(1-\alpha)}+\ln m\right] e^{-\rho t} d t
$$

subject to

$$
\dot{a}=\dot{m}+\dot{f}=y-c-\pi m-\pi_{f} f+\tau
$$

and

$$
a=m+f
$$

where $\tau=\pi m$, that is to say, agents are being lump-sum compensated for the opportunity cost of holding domestic real monetary balances. 
First order conditions for this maximization problem are:

$$
\begin{array}{r}
\frac{f^{1-\alpha}}{c^{\alpha}}=\lambda \\
\frac{1}{m}-\lambda \pi-\mu=0 \\
\frac{c^{1-\alpha}}{f^{\alpha}}-\lambda \pi_{f}-\mu=0 \\
-\dot{\lambda}+\rho \lambda=\mu
\end{array}
$$

and

$$
\lim _{t \rightarrow \infty} a \lambda e^{-\rho t}=0
$$

As we argued before, this utility function includes the convenient case that when $\alpha>1$, consumption and foreign monetary balances are substitutes in utility, that is to say, the cross partial derivative between consumption and foreign monetary balances is negative. This is necessary because the only way agents can increase their holdings of foreign balances is by giving up consumption.

Again, proceeding with the corresponding substitutions, and using the previous assumption on the growth rate of domestic monetary balances we get an equation on domestic monetary balances and an equation on the accumulation of 
foreign monetary balances. Then, we get the following:

$$
\dot{m}=(\sigma+\rho) m-1
$$

and

$$
\dot{f}=y-c-\pi_{f} f
$$

Then we get:

$$
\dot{m}=(\sigma+\rho) m-1
$$

and since from (7.13) $\lambda=1$, then $c=f^{\frac{1-\alpha}{\alpha}}$ and substituting into (7.19) we get the second dynamic equation of the model in terms of $f$ :

$$
\dot{f}=y-f^{\frac{1-\alpha}{\alpha}}-\pi_{f} f
$$

This parametrization has the characteristic that the level of foreign monetary balances will depend only on the level of income and on consumption. At the same time, domestic inflation will not affect the holdings of foreign monetary balances. Let us see the graph representing these equations: 


\section{Figure 7.2}

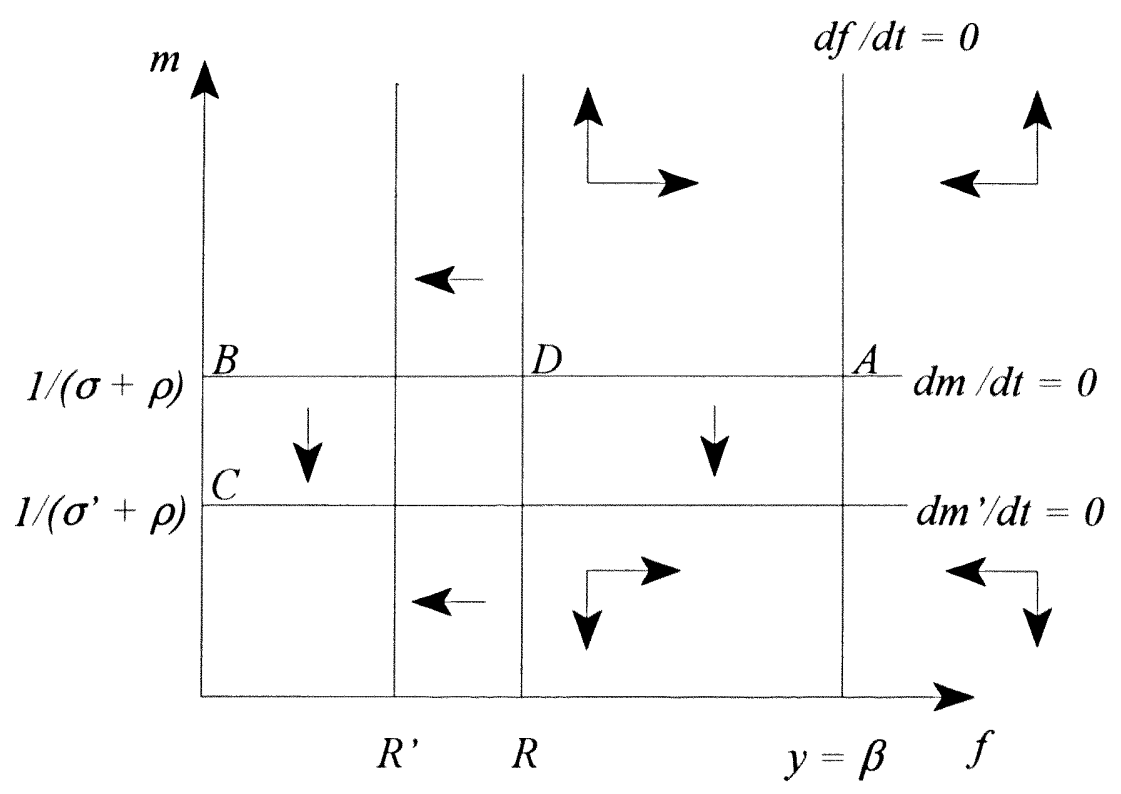

were $\beta=f^{\frac{1-\alpha}{\alpha}}+\pi_{f} f$, a constant, and $\mathrm{R}$ are reserves on the possession of the Central Bank amounting to the domestic money supply.

In this case, rational, speculative hyperinflations will not be possible because domestic monetary balances are essential in utility, that is to say, they cannot be zero. However, what is the monetary equilibrium in this figure? Without currency substitution, that is to say, with agents only using domestic monetary balances for transaction purposes, and using foreign monetary balances as a store of value, the monetary equilibrium will be at point B in Figure 7.2.

But when we assume currency substitution, or when agents start using not 
only domestic monetary balances for transaction purposes, but also foreign monetary balances, the economy will start to move from point $B$ towards point $D$ in Figure 7.2. However, this movement is only transitory as agents decrease their foreign monetary balances to increase consumption. This represents a transitory appreciation of the real exchange rate as we move from point $B$ towards point $D$ and back to point $B$, that is to say, domestic inflation will be higher than foreign inflation, which has been the characteristic of Argentina's situation since the introduction of the Convertibility Law in 1991.

This is also fully consistent with the aftermaths of the Mexican crisis of late 1994 by which agents proceeded to reduce the money supply by changing their pesos into dollars with the Central Bank, in the believe that the Argentine government will produce a nominal devaluation of the exchange rate (which has been pegged one-to-one to the dollar since 1991). This action is shown in figure 7.2 by a simultaneous shift in the R curve, from R to R' and in the $\frac{d m}{d t}=0$ curve, from $\frac{d m}{d t}=0$ to $\frac{d m^{\prime}}{d t}=0$. This action by agents shows the lack of control on the part of the government of the domestic money supply, which is constrained by the reserves held by the Central Bank.

However, the preceding discussion can be appreciated by looking at the process of accumulation-decumulation of foreign monetary balances. In order to look at this issue we need to introduce the relationship between consumption and foreign monetary balances. 
Using equations (7.19) and (7.13) we get two equations in consumption and foreign monetary balances:

$$
\begin{gathered}
\dot{f}=y-c-\pi_{f} f \\
\frac{c^{1-\alpha}}{f^{\alpha}}-\lambda \pi_{f}-\mu=0
\end{gathered}
$$

Using equation (7.13) to get an equation for $\dot{c}$, together with equation (7.15) we get the following two equations:

$$
\dot{c}=\frac{c^{2}}{\alpha} f-\frac{c}{\alpha}\left(\rho+\pi_{f}\right)+\frac{(1-\alpha)}{\alpha} \frac{c}{f} f
$$

and

$$
\dot{f}=y-c-\pi_{f} f
$$

Substituting (7.19) into (7.20) we get:

$$
\dot{c}=\frac{c^{2}}{\alpha} f-\frac{c}{\alpha}\left(\rho+\pi_{f}\right)+\frac{(1-\alpha)}{\alpha} \frac{c}{f}\left(y-c-\pi_{f} f\right)
$$

Then equations (7.19) and (7.20') generate a dynamic system in $c$ and $f$. Since at steady state $\dot{f}=0$ we get the following: 


$$
\left[\begin{array}{ll}
\frac{\partial \dot{c}}{\partial c} & \frac{\partial \dot{c}}{\partial f} \\
\frac{\partial \dot{f}}{\partial c} & \frac{\partial \dot{f}}{\partial f}
\end{array}\right]=\left[\begin{array}{cc}
{\left[\frac{2 c}{\alpha f}-\frac{\left(\rho+\pi_{f}\right)}{\alpha}\right]} & -\frac{c^{2}}{\alpha f^{2}} \\
-1 & -\pi_{f}
\end{array}\right]
$$

The determinant of this matrix is:

$$
-\pi_{f}\left[\frac{2 c}{\alpha f}-\frac{\left(\rho+\pi_{f}\right)}{\alpha}\right]-\frac{c^{2}}{\alpha f^{2}}<0
$$

The trace is:

$$
\left[\frac{2 c}{\alpha f}-\frac{\left(\rho+\pi_{f}\right)}{\alpha}\right]-\pi_{f}>0
$$

which means that the system is saddle path stable.

The slope of the $\dot{c}=0$ line is:

$$
\frac{c^{2}}{2 c-f\left(\rho+\pi_{f}\right)}>0
$$

The slope of the $\dot{f}=0$ line is:

$$
-\pi_{f}<0
$$

Graphically we have: 


\section{Figure 7.3}

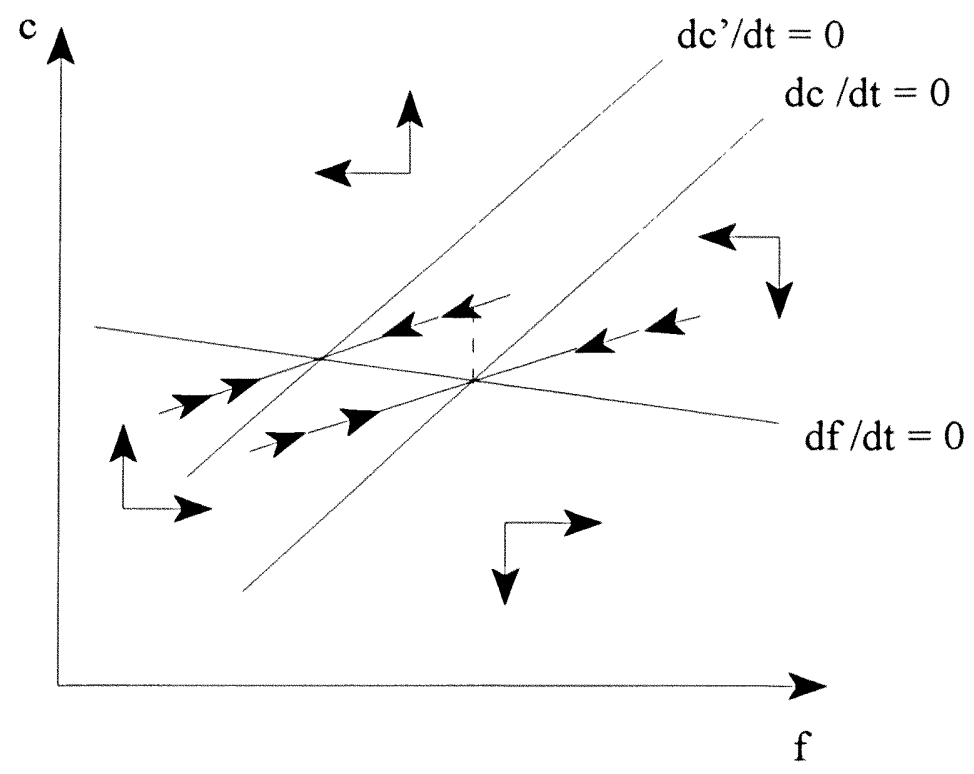

In this case an increase in the rate of growth of domestic money has no effect on the accumulation-decumulation of foreign monetary balances. However, let us assume that agents start using foreign monetary balances for transaction purposes, that is to say, currency substitution starts. What is the effect of this decision on the economy? The first effect will be given by an upward shift of the $\dot{c}=0$ line followed by a current account deficit (balance of payments deficit if capital is not mobile). This current account deficit will have the effect of decumulating foreign monetary balances, as they are used for transaction purposes, and if foreign 
inflation is positive, it will also increase consumption not only on impact but also on the new steady state.

Several reasons could be given for this type of behavior on the part of agents to take place. First, if the growth rate of domestic monetary balances is high, thus real domestic monetary balances are low, agents may start using foreign monetary balances so as to conduct economic transactions in the market. Second, if agents have accumulated sufficient foreign monetary balances during the years, they may be looking to increase consumption due to the increasing effect of foreign inflation over their holdings of those foreign monetary balances.

The opposite behavior is also true. If agents decide to increase their foreign monetary holdings, the $\dot{c}=0$ line will shift to the right creating a current account surplus and decreasing consumption on impact and on the new steady state to increase their foreign monetary balances. The interesting issue here is that this decision on the part of agents is independent from currency substitution. If agents decide to increase their foreign monetary holdings at some point in time, that does not mean that currency substitution increases, it only means that agents are accumulating foreign monetary balances as a store of value, not necessarily as a medium of exchange. However, as we have seen during this analysis, the opposite is not true. If agents decide to use their foreign monetary balances for transaction purposes (i.e., currency substitution), they have to decumulate those balances.

But Figure 7.3 is not the only dynamics of this system. By looking at the 
slope of the $\dot{c}=0$ equation we see that if consumption is very low, the sign of this slope may be negative. This gives us the dynamics of a "stable locus" by which a succession of current account deficits and surpluses will set in motion, just as we showed in Chapter 6 (Figure 6.3, p. 132).

\subsection{Conclusion}

The parametrization used in this chapter allowed us to simulate the case of Argentina in which domestic monetary balances have never lost its characteristic of being essential in utility by which rational, speculative hyperinflations, have to be ruled out. At the same time it allowed us to differentiate between the process of dollarization and currency substitution as two different phenomena, although related.

We showed also that there is an asymmetry between the two processes. While currency substitution implied a process of decumulation of foreign monetary balances, accumulation of foreign monetary balances does not necessarily implied currency substitution. 


\section{CHAPTER 8}

\section{CONCLUSIONS AND \\ POLICY RECOMMENDATIONS}

\subsection{CONCLUSIONS}

We conclude this dissertation with the firm believe that rational hyperinflations are not possible in Argentina as long as the domestic currency remains to be essential in utiltiy. However, the second strand of hyperinflation is ever more possible as the Argentine governmen increases the rate of growth of the domestic money supply. In so far as it is the legal tender for conducting economic transactions within the country, it is extremely difficult that domestic monetary balances could loose this characteristic.

Even if private agents use the foreign currency to conduct economic transactions, there are still basic transactions that must be conducted using the domestic currency. Furthermore, during the hyperinflationary periods of 1989 and 1990 , the domestic currency was even more essential that what it is today. The reason is that up until 1991 all public utility and a big portion of the goods and service industry such as telephones, trains, water, natural gas, airlines, electricity, etc., were in the hands of the government and agents had to use the domestic 
currency to settle debts.

Nowadays this has changed, and private agents can conduct transactions using the domestic or the foreign currency. However, there are still some transactions, such as public employees salaries and tax payments that must be conducted using the domestic currency.

Another argument put forward to show that the domestic currency was still essential in Argentina was the fact that not everybody in society was able to hoard foreign monetary balances, be it because of being low income individuals or because of lack of integration (geographical or otherwise) of the financial system.

We also showed that the distiction between cooperant and non-cooperant monetary balances is intimately related to the dollarization process (specifically with the decumulation-accumulation of dollars) and less so with the decission to use or not the foreign money to conduct transactions, that is to say, with currency substitution per se.

One of the characteristics of the period after the imposition of the Convertivility Law of 1991 has been that the domestic inflation rate has been higher than the dollar inflation rate. This was shown to be a consequence of the currency substitution phenomenon, that is to say, if currency substitution exists, the domestic inflation rate will be higher than the foreign inflation rate, even with a fixed growth of the domestic currency. 


\subsection{WHAT LIES AHEAD? POLICY RECOMMENDATIONS}

Argentina's economic problems are not easily solved, however, solutions are intimately and directly related to its political system and furthermore, to its political culture. If the policy of fixing the exchange rate to the dollar and putting the fiscal house in order is just the policy chosen only by the Peronist government, and depends on the continuity of President Menem and Finance Minister Cavallo, then the future does not look bright.

Efforts to modernize the political system have run short and have been extremely costly in political terms. The 1994 Constitutional Reform ran short in our opinion on several grounds. ${ }^{1}$ Two of the most important aspects are the following. The first one is itself a political argument. This is the fact that in Argentina, voting is not only a right in itself but it is also an obligation. That means that people have to vote even if they are not interested in voting or if they are not fully informed about the alternatives available. ${ }^{2}$ It is true, however, that people could vote in blank, that is to say, people go to vote but their vote does not count. However, data on blank votes shows that this type of voting expression is negligible. This issue is also

${ }^{1}$ We are leaving out the issue that has to do with reforming the legal and judiciary institutions because it will need a full dissertation on its own.

${ }^{2}$ This issue has been discussed by the author and Political Scientists from Argentina with agreement on the importance of this issue for the political system. 
related to the difference between political mobilization and institutionalization called "mass praetorianism."

The basic idea is that political institutions in Argentina are not well equipped to handle such a large political mobilization. This has provided well-organized institutions, such as the military sector in Argentina, the opportunity to get a handle on the political system arguing political disintegration of the country, or at least using this as an excuse to take over political power.

This argument is linked to our second issue, which relates to the maintenance of a fixed parity between the peso and the dollar but without fully dollarizing the economy. On the other hand, several authors have argued that Argentina should follow Chile, Colombia, and Mexico in establishing a crawling-peg exchange rate in order to minimize the overvaluation of the domestic currency due to stubborn inflationary expectations. However, the differences between the political systems in these later countries and Argentina are at the heart of our opposition to the implementation of a crawling-peg exchange rate system in Argentina. Chile, Colombia, and Mexico ${ }^{4}$ have been able to maintain very closed political systems. That is to say, they have been more successful than the Argentine political system to avoid this "mass praetorianism" by which the political mobilization of their masses

\footnotetext{
${ }^{3}$ See again Huntington (1968). See also footnote 8 on Chapter 2 of this Dissertation on page 56 .

${ }^{4}$ Although Mexico's political system is currently in crisis and it will probably collapse with yet unknown consequences for its future. See Alemán (1993).
} 
has out paced its institutionalization. However, these countries are not out of the risks of a break down of their political system. Complicating this issue even further is the fact that their military sectors are still the backbone of their political "stability."

The second issue then, and a much more conflictive one, is the lost opportunity to make the Convertibility Law of 1991 as a part of the Constitutional Reform. This could have been done at least until the political institutions were credible enough, and rational enough to understand the need to pursue and follow sound economic policy, even at the expense of slowing down the rate of growth of the economy, which has been very high in these last four years, in order to provide continuity and stability in the long-run.

The need for the above argument has to do with the issue that this is not the first time in history that the Argentine government has used the supply of money in order to finance fiscal deficits. In fact, this policy goes as far as the beginnings of the country as a Republic when each provincial government had power to print their own currency. This lack of concern for having a sound currency developed in one of the biggest financial crisis of the 19th. Century called the Baring Panic ${ }^{6}$ of 1890 and 1891.

\footnotetext{
${ }^{5}$ We should also include Peru in this group, which has a "pseudo-militarydemocratic" government.

${ }^{6}$ While writing this chapter, Baring Brothers of London has filed for bankruptcy in Great Britain, due to another bad investment policy, this time investing in high risk derivatives.
} 
Williams (1920) wrote about Argentina's economic and monetary policy during the period of 1885 to 1900 in the following way: "Through it all, paper was inconvertible and depreciated. It consists of a period of inflation and speculation culminating in the Baring Panic of 1890 and 1891, and of a subsequent nine or ten years of depression and very slow recovery. It ends with the Conversion Law of 1899, the act famous in Argentine history for having furnished at last a stable basis for the currency. From that time on the problem of a fluctuating premium on gold disappears." (Williams 1920, p. 23)

During those years, and due to the lack of integration to the world financial markets, individuals were not able to substitute their domestic currency balances for a strong currency, but nowadays, currency substitution, or the possibility of it, is perhaps, the only instrument that agents have to avoid unsound monetary policies and to pressure the government to commit to sound monetary policy and discipline.

This is even much more important when, as we have been arguing, full dollarization is a second best alternative due to the costs in terms of seigniorage paid to the U.S. government for holding dollars, and due to the trade-off between consumption and foreign monetary holdings.

The government, through the Convertibility Law of 1991, has been able to increase the monetary base as economic growth has increased (one dollar in reserve for each peso put into circulation), thus increasing seigniorage. This has 
been achieved by increasing foreign reserves available at the Central Bank. However, this increase in Central Bank reserves is probably the result of the selling off of state owned enterprises because the current account has been in deficit since the end of 1991. That is to say, once the government finishes the process of privatization, reserves would not be flowing in unless there is a reversal of this huge current account deficit. At the same time, the government has been having problems in order to maintain the fiscal superavit it had for the last two to three years.

Our argument in favor of a probably temporary, Convertibility Law as a part of a Constitutional Reform is directly linked to the credibility issue, so crucial for Argentina's political institutions. This is directly related to what is called a "Decreto de Necesidad y Urgencia" (roughly translated as an Emergency Decree, similar to an Executive Decree recently used by President Clinton to bail out the Mexican Economy) by which President Menem has assumed legislative powers in cases that he deemed necessary. President Menem has used this mechanism 330 times since he became president of Argentina in 1989 according to Delia Ferreira Rubio and Matteo Goretti. ${ }^{7}$ This would not be a problem probably if there was an independent judicial system, but this is not so in Argentina.

So, theoretically, there exist a real possibility that whenever necessary, the

${ }^{7}$ See Delia Ferreira Rubio and Matteo Goretti (1994) for a complete discussion on this important issue. 
president will use an Executive Decree to derogate the Convertibility Law of 1991. Ecuador tried this path toward improving the credibility of its economic decision by making their Convertibility Law an integral part of its Constitution and then derogated it through a governmental decree. Therefore, there are no guarantees that this would stand either. Then, it all boils down to Fischer's (1982) conclusion that "there is no absolutely guaranteed way of providing discipline for governments determined to avoid it." (Fischer 1982, p. 300)

He further concludes that "in those countries where dollarization is observed, it is usually the response to a government out of control rather than one setting the inflation rate on the basis of a careful optimizing analysis. Under such circumstances, use of a foreign money appears to provide a useful discipline on the monetary authority. But the system carries the seeds of its own destruction, since the value of the outstanding stock of currency is a seigniorage incentive to the government which introduces a domestic currency." (Fischer 1982, p. 307)

This conclusion supports our long held argument that, at least in the case of Argentina, currency substitution is not a choice on the part of the government to reduce inflation but the choice of each individual agent to avoid non-optimal inflation rate policies on the part of the Argentine government.

Credibility can also be improved by a further integration of Argentina into NAFTA, which will play a key role in setting the stage for having "lenders of last resort," such as the Federal Reserve System of the United States that will probably, 
just as it was done with Mexico recently, step in if faced with the possibility of a collapse of the system. 


\section{REFERENCES}

Alesina, A. and Drazen, A.; (1989), "Why are Stabilizations Delayed?," Working Paper No. 3053. National Bureau of Economic Research, Inc..

Arnaudo, A. A.; (1994), "Argentina's Financial Market in the Medium Term," Fundación Mediterránea Newsletter, Vol. 9, No. 8 (61), August 1994.

Arrow, K. J. and Kurz, M.; (1970), Public Investment, the Rate of Return, and Optimal Fiscal Policy, Published for Resources for the Future, Inc., by The Johns Hopkins Press.

Blanchard, O. J. and Fisher, S.; (1989), Lectures on Macroeconomics, The MIT Press.

Blanco, H. and Garber, P.; (1986), "Recurrent Develuation and Speculative Attacks on the Mexican Peso," Journal of Political Economy, Vol. 94, No. 1, 148-166. Blejer, M. I. and Cheasty, A.; (1988), "High Inflationm, Heterodox Stabilization, and Fiscal Policy," World Development, Vol 16, No. 8, 867-881.

Blejer, M. I.; (1988), "Estrategias y Políticas Fiscales de Transición en Recientes Experiencias de Hiperestabilización," Ensayos Sobre Política Económica, No. 13 , pp. 39-68, Junio.

Borcherding, T. and Silberberg, E.; (1978), "Shipping the Good Apples Out: The Alchian and Allen Theorem Reconsidered," Journal of Political Economy, Vol. 86 , No. 1. 
Brock, W. A.; (1974), "Money and Growth: The Case of Long Run Perfect Foresight," International Economic Review, Vol. 15, No. 3, 750-777, October. Brock, W. A. and Turnovsky, S. J.; (1981), "The Analysis of Macroeconomic Policies in Perfect Foresight Equilibrium," International Economic Review, Vol. 22, No. 1, 179-209.

Bruno, M. ; (1976), "The Two-Sector Open Economy and the Real Exchange Rate," The American Economic Review, Vol. 66, No. 4, 566-577, September.

Bufman, G. and Liederman, L.; (1992), "Simulating an Optimizing Model of Currency Substitution," Revista de Análisis Económico, Vol. 7, Nro. 1, pp. 109-124,Junio de 1992.

Bufman, G. and Leiderman, L.; (1993), "Currency Substitution under Nonexpected Utility: Some Empirical Evidence," Journal of Money, Credit, and Banking, Vol. 25, No. 3 (August, Part 1).

Buitter, W. H.; (1987), "Borrowing to Defend the Exchange Rate and the Timing and Magnitude of Speculative Attacks," Journal of International Economics, 23, 221-239. North-Holland.

Cagan, P.; (1956), "The Monetary Dynamics of Hyperinflation," in M. Friedman, Ed.. Studies in the Quantity Theory of Money, Chicago: University of Chicago Press.

Calvo, G. A.; (1977), "The Stability of Models of Money and Perfect Foresight: A Comment," Econometrica, Vol. 45, No. 7, 1737-1739, October. 
Calvo, G. A. and Rodríguez, C. A. ; (1977), "A Model of Exchange Rate Determinations under Currency Substitution and Rational Expectations," Journal of Political Economy, Vol. 85, No. 3, 617-625.

Calvo, G. A.; (1979), "On Models of Money and Perfect Foresight," International Economic Review, Vol. 20, No. 1, February.

Calvo, G. A.; (1981), "Devaluation: Levels versus Rates," Journal of International Economics, 11, 165-172. North Holland Publishing Company.

Calvo, G. A.; (1985), "Reserves and the Managed Float: a Search for the Essentials," Journal of International Money and Finance, 1, 43-60.

Calvo, G. A.; (1985), "Currency Substitution and the Real Exchange Rate: the Utility Maximization Approach," Journal of International Money and Finance, 4, 175-188.

Calvo, G. A.; (1986), "Temporary Stabilization: Predetermined Exchange Rates," Journal of Political Economy, Vol. 94, No. 6, 1319-1329.

Calvo, G. A., Leiderman, L., and Reinhart, C. M.; (1992), "Captal Inflows and Real Exchange Rate Appreciation in Latin America: The Role of External Factors," International Monetary Funds, Working Paper.

Calvo, G. A. and Végh, C. A.; (1994), "Stabilization Dynamics and BackwarkLooking Contracts," Journal of Development Economics, 43, 59-94. NorthHolland.

Calvo, G. A. and Végh, C. A.; (1992), "Currency Substitution in Developing 
Countries: An Introduction," Revista de Análisis Económico, Vol. 7, Nro. 1, pp. 3-27, Junio de 1992.

Cariaga, J. L.; (1989), "The Bolivian Stabilization Program (1985-1988): Notes on the Rebirth of Political Economy," Presented for the 64 Annual Western Economic Association International Conference, Contemporary Policy Issues, Lake Tahoe, June 22, 1989.

Di Tella, G. and Dornbusch, R.; (1989), The Political Economy of Argentina, 19461983, Di Tella, Guido and Rudiger Dornbusch, Eds., University of Pittsburg Press.

Dornbusch, R. and Frenkel, J. A.; (1973), "Inflation and Growth," Journal of Money, Credit, and Banking, 141-156.

Dornbusch, R. and Mussa, M.; (1975), "Consumption, Real Balances and the Hoarding Function," International Economic Review, 16:415-421.

Dornbusch, R. and Reynoso, A.; (1989), "Financial Factors in Economic Development," American Economic Association, Papers and Proceedings, Vol. 79 , No. 2, 204-209.

Dornbusch, R., Sturzenegger, F., and Wolf, H.; (1990), "Extreme Inflation:

Dynamics and Stabilization," Brookings Papers on Economic Activity, 1$84,2: 1990$.

Dornbusch, R. and de Pablo, J. C.; (1990), "Debt and Macroeconomic Instability in Argentina," in J. Sachs (ed.) Developing Country Debt and Economic 
Performance. Chicago: University of Chicago Press.

Dornbusch, R. and Werner, A.; (1994), "Mexico: Stabilization, Reform, and No Growth," Brookings Papers on Economic Activity, 1:1994, pp. 253-315.

Dornbusch, R.; (1995), "Progress Report on Argentina," Chapter 7, 223-238, in

Reform, Recovery, and Growth: Latin America and the Middle East, Ed. by Rudiger Dornbusch and Sebastian Edwards, NBER, The University of Chicago Press.

Edwards, S.; (1989), "Exchange Controls, Devaluation, and Real Exchange Rates:

The Latin American Experience," Economic Development and Cultural Change, 457-494.

Edwards, S. and Tabellini, G.; (1991), "Explaining Fiscal Policies and Inflation in Developing Countries," Journal of International Money and Finance, 10, S16S48.

Engel, C.; (1989), "The Trade Balance and Real Exchange Rate Under Currency Substitution," Journal of International Money and Finance, 8, 47-58.

Epstein, L. G. and Hynes, J. A.; (1983), "The Rate of Time Preference and Dynamic Economic Analysis," Journal of Politicl Economy, Vol. 91, No. 4, 611-635.

Epstein, L. G.; (1987), "A Simple Dynamic General Equilibrium Model," Journal of Economic Theory, 41, 68-95.

Fasano-Filho, U.; (1986), Currency Substitution and Liberalization: The Case of Argentina, Gower Publishing Company Limited, England, 1986. 
Ferreira-Rubio, D. and Goretti, M.; (1994), "The Emergency and the Relationship Between the Excecutive and the Congress During President Menem Administration in Argentina: Use and Misuse of Prerrogative Powers," in Lawrence Longley (Ed.), Working Papers on Comparative Legislative Studies, Lawrence University, Winsconsin, January, 1994.

Fischer, S.; (1972), "Money, Income, Wealth, and Welfare," Journal of Economic Theory, 4, 289-311.

Fischer, S.; (1979), "Capital Accumulation on the Transitiona Path in a Monetary Optimizing Model," Econometrica, Vol. 47, No. 6, 1433-1439, November.

Fischer, S.; (1981), "Is There a Real-Balance Effect in Equilibrium?," Journal of Monetary Economics, 8, 25-39. North-Holland Publishing Company.

Fischer, S.; (1982), "Seigniorage and fixed Exchange Rates: An Optimal Inflation Tax Analysis," Chapter 3 in Financial Policies and the World Capital Market: The Problem of Latin American Countries, Edited by Pedro Aspe Armella, Rudiger Dornbusch, and Maurice Obstfeld, The University of Chicago Press, Chicago and London.

Fischer, S.; (1982), "Seigniorage and the Case for a National Money," Journal of Political Economy, Vol. 90, No. 2, 295-313.

Fishlow, A. and Friedman, J.; (1994), "Tax Evasion, Inflation and Stabilization," Journal of Development Economics, 43 (1994) 105-123. North-Holland.

Giovannini, A.; (1991), "Currency Substitution and the Fluctuations of Foreign- 
Exchange Reserves with Credibly Fixed Exchange Rates," Working Paper

No. 3636 , National Bureau of Economic Research, Inc..

Giovannini, A and Turtelboom, B.; (1992) "Currency Substitution," Working Paper

No. 4232, National Bureau of Economic Research, Inc..

Girton, L. and Roper, D.; (1981), "Theory and Implications of Currency

Substitution," Journal of Money, Credit, and Banking, Vol. 13, No. 1, 12-30, (February).

Guidotti, P. E.; (1993), "Currency Substitution and Financial Innovation," Journal of Money, Credit, and Banking, Vol. 25, No. 1 (February).

Hanke, S. H. and Schuler, K.; (1994), Currency Boards for Developing Countries:

A Handbook, Sector Study No. 9, International Center for Economic Growth, ICS Press.

Hercowitz, Z. and Sadka, E.; (1992 ), "On Optimal Currency Substitution Policy and Public Finance," Economic Policy in Theory and Practice, Ed. By Assaf Razin and Efraim Sadka. St. Martin's Press, New York.

Huntington, S. P.;(1968) "Praetorianism and Political Decay," Chapter 4 in Political Order in Changing Societies, Yale University Press, New Haven and London Ireland, P. N.; (1994), "Money and Growth: An Alternative Approach," American Economic Review, March 1994, p. 48

Isaac, A. G.; (1989), "Exchange Rate Volatility and Currency Substitution," Journal of International Money and Finance, 8, 277-284. 
Joines, D. H.; (1985), "International Currency Substitution and Income Velocity of Money," Journal of International Money and Finance, 4, 303-316.

Judd, K.; (1985), "Redistributive Taxation in a Simple Perfect Foresight Model," Journal of Public Economics, 28, 59-83. North-Holland.

Karayalcin, C.; (1992), "Heterogeneous Households, The Distribution of Wealth, and The Laursen-Metzler Effect," Mimeo, Florida International University.

Karayalcin, C.; (1992), "Redistributive Taxation in a Small Open Economy," Mimeo, Florida International University.

Karayalcin, C.; (1992), "Supply Schoks, Time Preferences and Optimal International Lending," Mimeo, Florida International University.

Karayalcin, C.; (1994), "Adjustment Cost in Investment, Time Preference, and the Current Account," Journal of International Economics, 37, 81-95.

Kiguel, M. A.; (1989), "Budget Deficits, Stability, and the Monetary Dynamics of Hyperinflation," Journal of Money, Credit, and Banking, Vol. 21, No. 2 (May 1989).

Kiguel, M. A. and Liviatan, N.; (1989), "The Old and the New in Heterodox Stabilization Programs: Lessons from the Sixties and the Eighties," Mimeo. Kim, K-S.; (1985), "Currency Substitution in a Production Economy," Journal of International Economics, 18, 141-158. North-Holland.

Krugman, P. R.; (1978), "Purchasing Power Parity and Exchange Rates: Another Look at the Evidence," Journal of Internationlal Economics, 8 (1978) 397- 
407. North -Holland Publishing Company.

Krugman, P. and Taylor, L.; (1978), "Contractionary Effects of Devaluation," Journal of International Economics, 8, 445-456. North-Holland Publishing Company. Krugman, P.; (1979), "A Model of Balance of Payments Crises," Journal of Money. Credit, and Banking, 3:311-325.

Lapan, Harvey E. and Enders, W.; (1983), "Rational Expectations, Endogenous Currency Substitution, and Exchange Rate Determination," The Quarterly Journal of Economics, 429-439, August.

Liviatan, N.; (1981), "Monetary Expansion and Real Exchange Rate Dynamics," Journal of Political Economy, Vol. 89 , No. 6, 1218-1227.

Liviatan, N.; (1984), "Tight Money and Inflation," Journal of Monetary Economics, 13, 5-15. North-Holland.

McKinnon, R. I.; (1982 ), "Currency Substitution and Instability in the World Dollar Standard," The American Economic Review, Vol. 72, No. 3, 320-333, June.

Miles, M. A.; (1978), "Currency Substitution, Flexible Exchange Rates, and Monetary Independence," American Economic Review, Vol. 68, No. 3, 428436.

Obstfeld, M.; (1981), "Capital Mobility and Devaluation in an Optimizing Model with Rational Expectations," American Economic Association, Papers and Proceedings, Vol. 71, No. 2, 217-221, May.

Obstfeld, M. and Rogoff, K.; (1983), "Speculative Hyperinflations in Maximizing 
Models: Can We Rule Them Out?," Journal of Political Economy, Vol. 91, No. $4,675-687$.

Obstfeld, M.; (1984), "Multiple Stable Equilibria in an Optimizing Perfect-Foresight Model," Econometrica, Vol. 52, No. 1, 223-228.

Obstfeld, M.; (1984), "Balance-of-Payments Crises and Devaluation," Journal of Money, Credit, and Banking, Vol. 16, No. 2 , 208-217, (May).

Obstfeld, M.; (1985), "The Capital Inflows Problem Revisited: A Stylized Model of Southern Cone Disinflation," Review of Economic Studies, (1985) LII, 605625.

Obstfeld, M.; (1990), "Intertemporal Dependence, Impatience, and Dynamics," Journal of Monetary Economics, 26, 45-75. North-Holland.

Ortiz, G.; (1983), "Dollarization in Mexico: Causes and Consequences," in Pedro Aspe et al. (Eds), Financial Policies and the World Capital Market: The Problem of Latin American Countries, Chicago: Chicago University Press.

Penati, A.; (1987), "Government Spending and the Real Exchange Rate," Journal of International Economics, 22, 237-256. North-Holland.

Penati, A. and Pennacchi, G.; (1989), "Optimal Portfolio Choice and the Collapse of a Fixed-Exchange Rate Regime," Journal of International Economics, 27, 1-24. Norht-Holland.

Ramirez-Rojas, C. L.; (1985), "Currency Substitution in Argentina, Mexico and Uruguay," International Monetary Fund, Staff Papers, 32: 629-667. 
Rodriguez, C. A.; (1978), "A Stylized Model of the Devaluation-Inflation Spiral," International Monetary Fund, Staff Papers, (March): 76-89.

Rodriguez, C. A.; (1981), "Managed Float: An Evaluation of Alternative Rules in the Presence of Speculative Capital Flows," The American Economic Review, Vol. 71 , No. 1, 256-260, March.

Rodríguez, C. A.;(1994a), "Argentina: Fiscal Disequilibria Leading to Hyperinflation," Chapter 3, Public Sector Deficits and Macroeconomic Performance, Edited by William Easterly, Carlos Alfredo Rodríguez, and Klaus Schmidt-Hebbel, Published for the World Bank by Oxford University Press, pp. 101-166.

Rodríguez, C. A.;(1994b), "The External Effects of Public Sector Deficits," Chapter

2. Public Sector Deficits and Macroeconomic Performance, Edited by William Easterly, Carlos Alfredo Rodríguez, and Klaus Schmidt-Hebbel, Published for the World Bank by Oxford University Press, pp. 79-97.

Rogers, J. H.; (1992), "The Currency Substitution Hypothesis and Relative Money Demand in Mexico and Canada," Journal of Money, Credit, and Banking, Vol. 24, No. 3 (August 1992).

Rostowski, J.;(1992), "The Benefits of Currency Substitution During High Inflation and Stabilization," Revista de Análisis Económico, Vol. 7, Nro. 1, pp. 91107, Junio de 1992.

Savastano, M. A.; (1990), "Speculative Attacks and Currency Substitution Under 
Managed Exchange Rate Regimes in Developing Countries," Unpublished Dissertation.

Savastano, M. A.; (1992), "The Pattern of Currency Substitution in Latin America:

An Overview," Revista de Análisis Económico, Vol. 7, Nro. 1, pp. 29-72, Junio de 1992.

Sidrauski, M.; (1967), "Inflation and Economic Growth," Journal of Political Economy, 75 pp. $798-810$.

Sidrauski, M.; (1967), "Rational Choice and Patterns of Growth in a Monetary Economy," American Economic Review, 534-544, May.

Sturzenegger, F.; (1991), "Essays on Inflation and Financial Adaptation,"Unpublished Ph. D. Dissertation, MIT.

Sturzenegger, F.; (1994), "Hyperinflation With Currency Substitution: Introducing an Indexed Currency," Journal of Money, Credit, and Banking, Vol. 26, No. 3, pp. 377-395 (August 1994, Part 1).

Sturzenegger, F.; (1992), "Currency Substitution and the Regressivity of Inflationary Taxation," Revista de Análisis Económico, Vol. 7, Nro. 1, pp. 177-192, Junio de 1992.

Sturzenegger, F.; (1992), "Inflation and Social Welfare in a Model with Endogenous

Financial Adaptation," Working Paper No. 4103, National Bureau of Economic Research, Inc. .

Surman, D. S.; (1982), "Transactions Costs, Foreign Exchange Demands, and the 
Expected Rates of Change of Exchange Rates," Journal of Money, Credit, and Banking, Vol. 14, No. 1 (February).

Tanzi, V.; (19 ), "Inflation, Real Tax Revenue, and the Case for Inflationary Finance: Theory with an Application to Argentina," International Monetary Fund, Staff Papers, 417-451.

Thomas, L. R.; (1985), "Portfolio Theory and Currency Substitution," Journal of Money, Credit, and Banking, Vol. 17, No. 3 (August).

Végh, C. A.; (1989), "The Optimal Inflation Tax in the Presence of Currency Substitution," Journal of Monetary Economics, 24 139-146. North-Holland.

Wan, H. Y. Jr.; (1970), "Optimal Saving Programs Under Intertemporally Dependent Preferences," International Economic Review, Vol. 11, No. 3, 521-547, October.

Weil, P.; (1991), "Currency Competition and the Transition to Monetary Union: Currency Competition and the Evolution of Multi-Currency Regions," Chapter 10, Ed. by Alberto Giovannini and Colin Mayer, CEPR-IMI, Cambridge University Press.

Williams, J. H.; (1920), Argentine International Trade Under Inconvertible Paper Money 1880-1900, Originally published in 1920, and reprinted by Greenwood Press, Publishers, New York, 1969.

Zou, Heng-Fu; (1993), "Dollarization and Inflation in a Two-Country Optimization Model," Journal of International Money and Finance, 12, 209-220. 


\section{VITA}

January 19, 1961

Born, Buenos Aires, Argentina

STUDIES:

1984

Licenciado en Ciencial Política

Universidad Del Salvador

Buenos Aires, Argentina

1991

Master in Business Administration

Inter-American University

Rio Piedras, Puerto Rico

1991

Master of Arts in Economics

Florida International University

Miami, Florida

EXPERIENCE:

$1985-1990$

General Manager

Che's Inc.

Punta Las Marias

Santurce, Puerto Rico

$1990-1993$

Teaching Assistant

Florida International University

Miami, Florida

1993

Senior Advisor B

Centro de Economía Internacional

United Nations Development Program

Buenos Aires, Argentina

1993-1995

Adjunct Lecturer

Florida International University

Mimi, Florida 


\section{PUBLICATIONS AND PRESENTATIONS}

Alemán, E.; (1993), “Argentina ante el Siglo XXI: ¿lntegración Como Estrategia de Crecimiento?," Centro de Economía Internacional (CEI), Ministerio de Relaciones Exteriores y Culto and United Nations Development Program, Project \# Arg/87/014.

Alemán, E.; (1994), "Actores e Intereses Económicos en la Formación del Mercosur y del NAFTA: Orígenes y Desarrollo," Paper presented at the Seminar "Unione Europea e Mercosud: il disegno istituzionale nei processi di integrazione regionale." Milan, Italy, October 11-12, 1994. 